\title{
EARNINGS ATTRIBUTES AND INVESTOR \\ PROTECTION: INTERNATIONAL \\ EVIDENCE
}

\author{
By \\ KRIENGKRAI BOONLERT-U-THAI \\ Master of Accountancy \\ Chulalongkorn University \\ Bangkok, Thailand \\ 1995 \\ Master of Science \\ Oklahoma State University \\ Stillwater, Oklahoma \\ 2001
}

Submitted to the Faculty of the

Graduate College of the

Oklahoma State University

in partial fulfillment of

the requirements for

the Degree of

DOCTOR OF PHILOSOPHY

December, 2005 


\section{EARNINGS ATTRIBUTES AND INVESTOR \\ PROTECTION: INTERNATIONAL \\ EVIDENCE}

Dissertation Approved:

\begin{tabular}{c} 
Gary K. Meek \\
\hline $\begin{array}{c}\text { Dissertation Adviser } \\
\text { Don R. Hansen }\end{array}$ \\
\hline Sandeep Nabar \\
Ramesh P. Rao \\
A. Gordon Emslie
\end{tabular}




\section{ACKNOWLEDGMENTS}

I wish to express my sincere gratitude to my dissertation committee members, Dr. Don R. Hansen, Dr. Sandeep Nabar, and Dr. Ramesh P. Rao for their guidance, suggestions, and encouragement throughout the dissertation stage. I am grateful and especially indebted to my dissertation chairman, Dr. Gary K. Meek, who consistently guided me and greatly facilitated the progress of my dissertation. He is possibly the best dissertation chairman one could hope to have. I am thankful to Dr. Amy Lau, Dr. Vorasak Toommanon, and Dr. Charlotte Wright, who guided and encouraged me into the doctoral program at Oklahoma State University. I also recognize and appreciate the support and assistance of Dr. Shahrokh Saudagaran, Dr. Wayne Thomas, Dr. Don Herrmann, Dr. Christian Leuz, Dr. Ilia Dichev, and Dr. Cecil Dugger.

I am thankful to Ms. Cristina Escober for her patience, support, and encouragement during the time in Stillwater, Oklahoma. I wish to express my appreciation to my parents, relatives, friends, fellow doctoral students, and colleagues at Chulalongkorn University for their support and encouragement throughout the course of my study. Finally, I wish to thank the Faculty of Commerce and Accountancy, Chulalongkorn University for providing generous financial support and the School of Accounting and the Spears School of Business, Oklahoma State University for providing scholarships and research assistantships in the dissertation stage. 


\section{TABLE OF CONTENTS}

$\begin{array}{ll}\text { Chapter } & \text { Page }\end{array}$

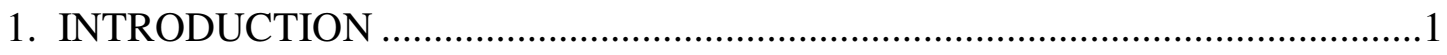

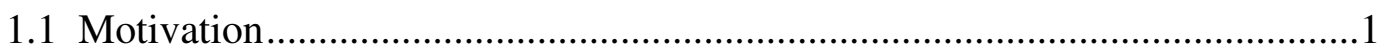

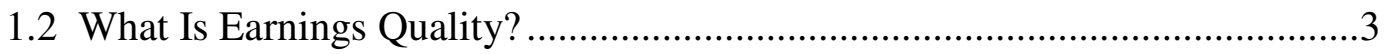

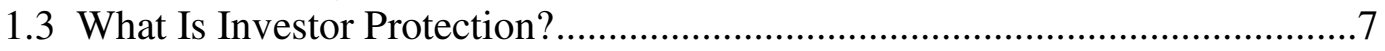

1.4 A Linkage Between Investor Protection and Earnings Quality ………….........

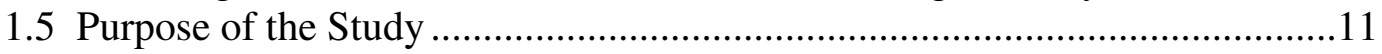

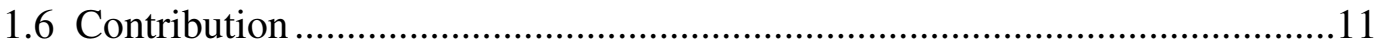

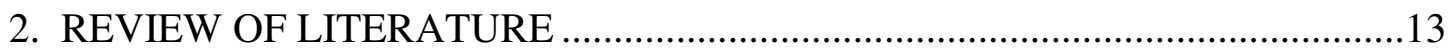

2.1 Foundation of Investor Protection Studies........................................................13

2.2 Effects of Institutional Variables on Earnings Management .............................14

2.3 Effects of Institutional Variables on Value Relevance of Earnings ................16

2.4 Effects of Institutional Variables on Informativeness of Earnings ..................16

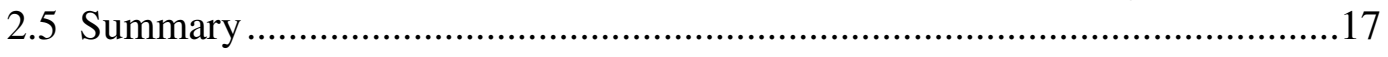

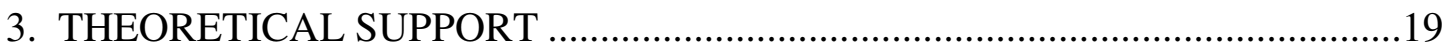

3.1 Earnings Attributes Measures ................................................................19

3.1.1 Accruals Quality ..........................................................................19

3.1.2 Earnings Persistence .........................................................................21

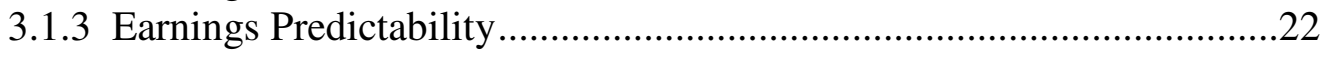

3.1.4 Earnings Smoothness ………………………….........................23

3.2 Investor Protection Measures....................................................................24

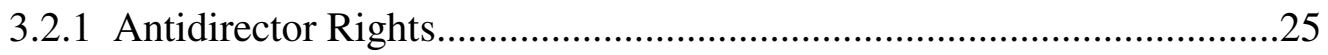

3.2.2 Law Enforcement: Efficiency of Judicial System .................................25

3.2.3 Law Enforcement: Rule of Law..........................................................26

3.2.4 Law Enforcement: Corruption Index ....................................................26

3.2.5 Importance of Equity Market: External Cap/GDP Ratio.........................26

3.2.6 Importance of Equity Market: Domestic Firms/Pop Ratio ......................27

3.2.7 Importance of Equity Market: IPOs/GDP Ratio .....................................27

3.2.8 Ownership Concentration ...............................................................28 


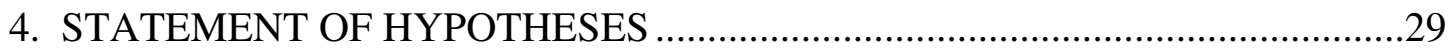

4.1 Results of H1 Are Consistent Across Four Earnings Attributes.......................30

4.2 Results of H1 Are Mixed Across Four Earnings Attributes..............................30

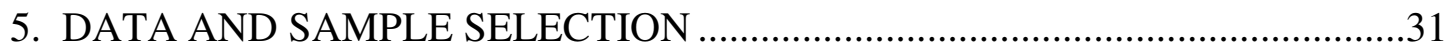

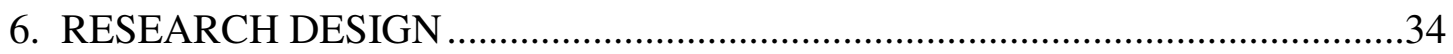

6.1 K-means Cluster and Correlation Analyses .......................................................

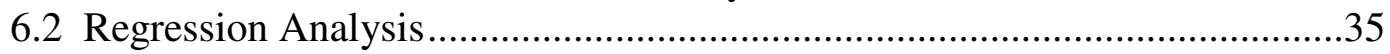

6.2.1 Results of H1 Are Consistent Across Four Earnings Attributes.............35

6.2.2 Results of H1 Are Mixed Across Four Earnings Attributes.....................38

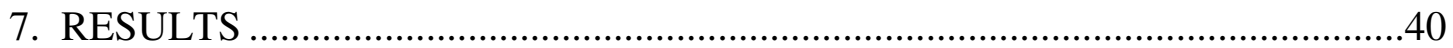

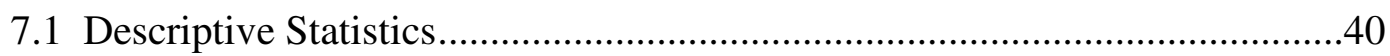

7.1.1 Descriptive Statistics: Institutional Characteristics ................................40

7.1.2 Descriptive Statistics: Earnings Attributes ...........................................41

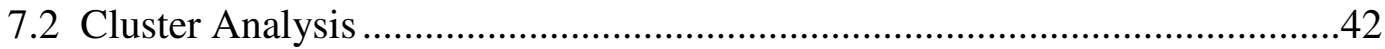

7.2.1 K-Means Cluster Analysis: Institutional Characteristics ..........................42

7.2.2 K-Means cluster Analysis: Earnings Attributes.......................................44

7.3 Correlation Analysis ................................................................................47

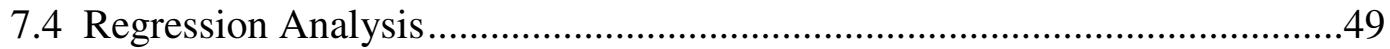

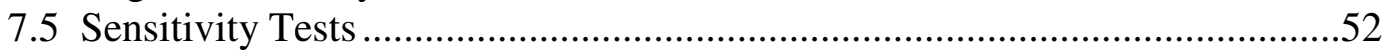

7.5.1 Sensitivity Test: Earnings Attributes and Institutional Characteristics (Rank Data) ......................................................................53

7.5.2 Sensitivity Test: Scaling Accounting Variables Using Average Total Assets ...............................................................................55

7.5.3 Sensitivity Test: Not Including Change in Taxes Payable in Total Accrual Calculation .......................................................................56

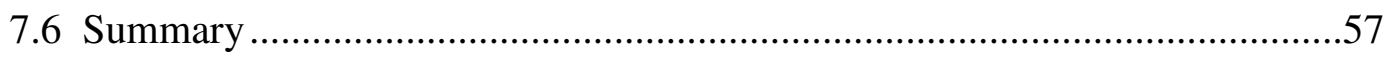

8. SUMMARY AND CONCLUSIONS, LIMITATIONS AND

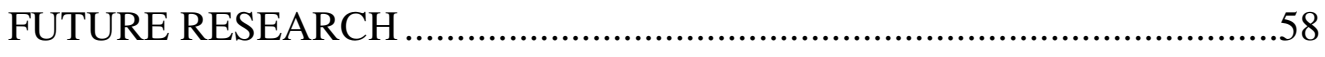

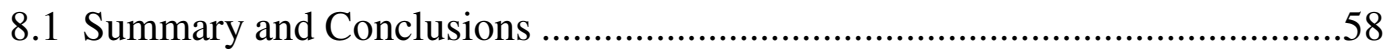

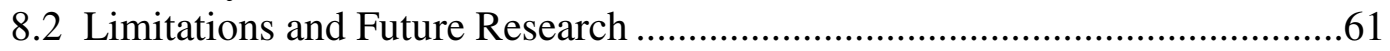

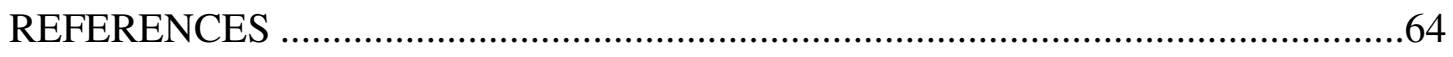

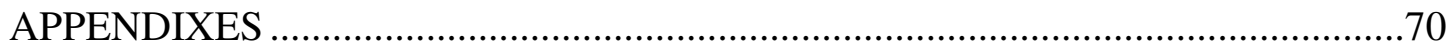

APPENDIX 1 - Earnings Quality Definitions and Measures ...................................71 
APPENDIX 2 - Data Source ..................................................................... 73

APPENDIX 3 - Tables and Figure ............................................................ 74 


\section{LIST OF TABLES}

Table $\quad$ Page

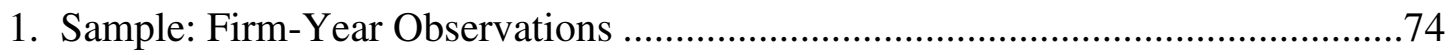

2. Investor Protection Proxies by Country .................................................................77

3. Sample Country's Mean Accounting Variables .......................................................80

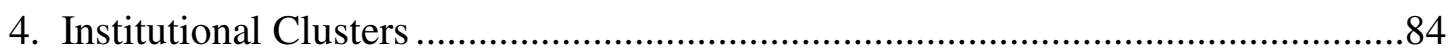

5. Institutional Clusters and Earnings Attributes ........................................................86

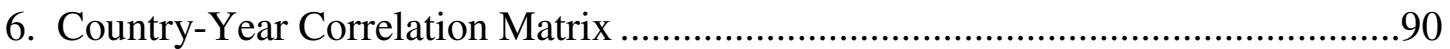

7. Country-Year Regression Analysis Between Earnings Attributes and Investor

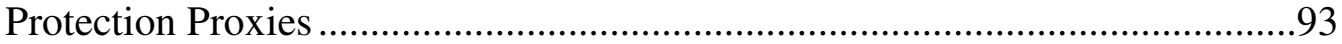

8. Sensitivity Test 1: Regression Analysis Between Earnings Attributes and Investor Protection Proxies .....................................................................................

9. Sensitivity Test 2: Country-Year Correlation Matrix .............................................103

10. Sensitivity Test 3: Country-Year Correlation Matrix ...........................................105 


\section{LIST OF FIGURES}

Figure

Page

1. Empirical Relations Between Earnings Attributes and Investor Protection ..........107 


\section{CHAPTER 1}

\section{INTRODUCTION}

\subsection{Motivation}

A major motivation for accounting research is providing evidence on how earnings is useful to a wide range of users in making economic decisions. Of particular interest over the last decade has been the issue of the quality of accounting reports, particularly the quality of earnings. For instance, in September 1998, Arthur Levitt, the Chairman of the Securities and Exchange Commission (SEC), presented "The Numbers Game" topic at New York University and called attention to an escalating problem with the quality of financial reporting in filings with the SEC. This topic received a great deal of attention over the next several years and is an important issue today because of the reliance of both U.S. and non-U.S. capital markets on credible financial reporting. The question of earnings usefulness is of major importance to users of financial information as well as to practitioners, regulators, and accounting researchers since earnings is widely believed to be the premier information item provided in financial statements (Lev 1989). Schipper and Vincent (2003) explain the importance of earnings quality as follows:

- From an investment perspective, low-quality earnings are undesirable because they provide a defective resource allocation signal. Low-quality earnings are inefficient because they reduce economic growth by causing capital to be misallocated. 
- From a financial information user perspective, earnings, and metrics derived from it, are commonly used in compensation arrangements and in debt agreements. For example, overstated earnings, used as an indicator of managers' performance, will result in overcompensation to managers. Similarly, overstated earnings might mask deteriorating solvency, leading lenders mistakenly to continue lending or to defer foreclosure.

- From an accounting standard setting perspective, accounting standard setters seek feedback on whether the standards they promulgate are effective, they tend to focus on outputs, including reporting earnings. The FASB's Conceptual Framework points to decision usefulness as the benchmark for assessing effectiveness. ${ }^{1}$

Teets (2002) documents three distinct sets of decisions that affect the quality of earnings: (1) decisions made by standard setters, (2) choices made by management about which accounting methods should be chosen from a set of acceptable alternatives, and (3) judgments and estimates made by management in order to implement the chosen alternatives. $^{2}$ Besides the three factors, several international studies (e.g., Ali and Hwang 2000; Ball et al. 2000; Hung 2001; Leuz et al. 2003; Ashbaugh and LaFond 2003; DeFond et al. 2004; Fulkerson et al. 2004) reveal that a number of important differences

\footnotetext{
1 Conceptual frameworks of other accounting standard-setters such as International Accounting Standard Board (IASB) and Accounting Standard Board (ASB) also point to decision usefulness as the benchmark for assessing effectiveness. The objective of IASB's framework is to provide information about the financial position, performance, and changes in financial position of an enterprise that is useful to a wide range of users in making economic decisions. 2

Teets (2002) documents that earnings management is a concept related to earnings quality, but clearly not synonymous. Earnings management activities can affect quality of earnings on each of these three dimensions.
} 
in the properties of earnings among countries are shaped by the extent of legal protection afforded outside investors from expropriation by controlling shareholders or managers.

This study attempts to explore the relationship between cross-country differences in the quality of reported earnings (proxied by four accounting-based earnings attributes) and investor protection. Definitions of earnings quality and investor protection, the importance of a linkage between them, and the contribution of this study are described as follows.

\subsection{What Is Earnings Quality?}

"Quality of earnings" is a multidimensional concept and there is no agreed-upon definition in the literature. Schipper and Vincent (2003) define the quality of earnings as the extent to which reported earnings faithfully represent Hicksian income. ${ }^{3}$ Since the Hicksian income is unobservable, Schipper and Vincent (2003) consider three earnings quality constructs: persistence; predictive ability; and the time-series variance of earnings as measures of earnings quality. ${ }^{4}$ These constructs are consistent with the Conceptual Framework which suggests that earnings quality might be assessed by some combination

3 Financial Accounting Standard Board (FASB) (1980) documents that representational faithfulness means "correspondence or agreement between a measure or description and the phenomenon that it purports to represent" (See FASB Concept No. 2, para. 63). Hicks (1939) defines "Hicksian: income as the amount that can be consumed (that is, paid out as dividends) during a period, while leaving the firm equally well off at the beginning and the end of the period. With this concept, high earnings quality occurs when earnings are closer to Hicksian income. 4

The time-series variance of earnings are (1) the relations among cash, accruals, and income, (2) the correspondence to relevance, reliability, and comparability, and (3) the effects of implementation decisions (e.g., unintentional estimation errors in accruals and intentional accruals manipulations). 
of persistence, predictive ability, and variability of earnings ${ }^{5}$ (Schipper and Vincent 2003).

The empirical literature has developed certain measures of earnings quality. Appendix 1 describes how prior research studies define and measure quality of earnings. Studies such as Dechow and Dichev (2002), Balsam et al. (2003), Francis et al. (2003), and Myers et al. (2003) use accruals quality to draw conclusions about earnings quality and view earnings to be of higher quality if accruals quality is high. ${ }^{6}$ Dechow and Dichev (2002), Beneish and Vargus (2002), Penman and Zhang (2002), and Richardson (2003) view earnings to be of higher quality when earnings is more persistent. Mikhail et al. (2003) define earnings quality as the extent to which a firm's past earnings is associated with its future cash flows, where high earnings quality occurs when a firm's earnings has high predictability. Some studies such as Lang et al. (2003) and Ball and Shivakumar (2004) view earnings to be of higher quality when it has less earnings management and more timely recognition of bad news.

As discussed more fully in Section 3, this study uses the following earnings attributes as indicators of earnings quality: (1) accruals quality, which refers to the extent to which accruals shift or adjust the recognition of cash flows over time so that the adjusted number (earnings) measures firm performance and predicts future earnings and cash flows, (2) earnings persistence, which refers to the extent to which an innovation (unexpectedness) in the earnings series causes investors to revise their future earnings

5 The variability of earnings refers to the time-series variance of earnings which are the relations among cash, accruals and income, the correspondence to relevance, reliability, and comparability, and the effects of implementation decisions (e.g. unintentional estimation errors in accruals and intentional accruals manipulations).

6

Accruals quality refers to the extent to which accruals map into the related cash flow realization, where a high match signifies high accruals quality (Dechow and Dichev 2002). 
expectations $^{7}$ (Kormendi and Lipe 1987; Lev 1989), (3) earnings predictability, which refers to the ability of earnings to predict itself, and (4) earnings smoothness, which refers to the use of accruals to smooth earnings. In this study, higher quality of earnings occurs when firm has (1) high accruals quality that shifts or adjusts the recognition of cash flows over time so that the adjusted earnings better measures firm performance and better predicts the future earnings and cash flows, (2) persistent components embedded in earnings that are sustainable, (3) high earnings predictability such that past earnings can predict future earnings very well, ${ }^{8}$ or (4) less earnings smoothness such that firm's management has not engaged in smoothing practices. ${ }^{9}$

Evaluating the quality of earnings helps the financial statement users make judgments about the "certainty" of current income and the prospects for the future (Deloitte \& Touche 2004). The following describes benefits of high quality of earnings:

\section{Financial information user perspective}

- Financial statements provide "actual" firm performance and high quality financial information that will be of real value to investors (Ricol 2004).

- Business decisions are improved as financial information users receive "true" firm performance for their decision making. For example, better accounting

\footnotetext{
7 Unexpected earnings consists of "persistent" and "transitory" components. Earnings persistence affects expectations of future earnings and cash flows while transitory earnings does not affect expectations. 8

Since earnings predictability refers to the ability of past earnings to predict future earnings (Lipe 1990), it is linked to a specific task, and is a decreasing function of the variance of earnings innovations. Hence, there is a possible contradiction between the persistence and predictive ability of earnings (i.e., earnings that are of high quality on the persistence dimension may be of low quality on the predictive ability dimension).

9

Management can engage in earning smoothing practices by introducing transitory components to the income series in order to decrease time-series variability and increase earnings predictability (Schipper and Vincent 2003). In addition, Former SEC Chairman Arthur Levitt (1998) holds that managers smooth earnings because they believe investors prefer smoothly increasing earnings.
} 
information helps investors and managers identify and distinguish between good and bad opportunities for investing financial capital and increasing the productivity of assets in place (Bushman and Smith 2001).

Investment perspective

- High quality earnings supports the development of capital markets, an especially important goal in emerging economies, in the European Union, and elsewhere. When the public is not confident in the financial reporting process or in the financial information released as part of that process, they are discouraged from making investments. This, in turn, prevents capital market growth (Ricol 2004).

- High quality earnings supports higher economic growth as it increases the credibility of financial information which is directly linked to economic development (Ricol 2004).

- High quality earnings results in lower cost of capital as it reduces information risk that is associated with decreased cost of equity and increased trading. An increase in earnings opacity is linked to an increase in the cost of equity and a decrease in trading in the stock markets (Bhattacharya et al. 2003).

- Greater willingness on the part of investors to invest across borders. When investors are confident with a firm's earnings quality in a country, they invest more for securities in that country.

Accounting standard setting perspective

- High quality earnings supports more efficient allocation of resources as it provides financial information that will be of real value to policy makers (i.e., the accounting profession, regulators, and financial institutions) who are faced with 
making decisions on how to allocate both financial and personal resources to aid economic development (Ricol 2004).

- High quality earnings supports the objective of conceptual frameworks in providing useful information such as a firm's performance to financial accounting users.

\subsection{What Is Investor Protection?}

Investor protection is defined as the protection of outside investors by the enforcement of regulations and laws (Shleifer and Wolfenzon 2002) or as a key institutional factor affecting firm policy choices such as shareholder voting rights and financial system policies (Shleifer and Vishny 1997; La Porta et al. 2000). La Porta et al. (2000) indicate that protected shareholder rights include those to receive dividends on pro-rata terms, to vote for directors, to participate in shareholders' meeting, to subscribe to new issues of securities on the same terms as the insiders, to sue directors or the majority for suspected expropriation, and to call extraordinary shareholders' meeting. If there is no investor protection, insiders can steal a firm's profits by manipulating accounting numbers. For example, insiders can use their financial reporting discretion to (1) overstate earnings and conceal unfavorable earnings realizations (i.e., losses) that would prompt outsider interference, and (2) understate earnings in years of good performance by creating reserves for future periods, effectively making reported earnings less variable than the firm's true economic performance (Leuz et al. 2003). ${ }^{10}$ Hence, investors should understand the differences in laws and the effectiveness of investors'

10

The term "insiders" is referred to both managers and controlling shareholders (La Porta et al. 2000). 
enforcement across countries in order to protect their rights and make sure that the returns on their investments will not be expropriated by the controlling shareholders or managers (La Porta et al. 2000). The following are benefits of high investor protection:

\section{Financial markets}

- Investor protection encourages the development of financial markets. When investors are protected from expropriation, they pay more for securities, making it more attractive for entrepreneurs to issue these securities (La Porta et al. 2000).

- Countries that protect shareholders have more valuable stock markets, larger numbers of listed securities per capita, and a higher rate of IPO (initial public offering) activity than do the unprotective countries (La Porta et al. 1997).

\section{Real consequences}

- Investor protection influences the real economy (La Porta et al. 2000). For example, high investor protection supports financial development and can accelerate economic growth by (1) enhancing saving, (2) channeling these savings into real investment and thereby foster capital accumulation, and (3) allowing capital to flow toward the more productive uses, and thus improve the efficiency of resource allocation (Beck et al. 2000).

- Country-level legal institutions are crucial elements in explaining capital market development (La Porta et al. 2000; Shleifer and Wolfenzon 2002).

\subsection{A Linkage Between Investor Protection and Earnings Quality}

The extent of investor protection varies greatly around the world. Shleifer and Vishny (1997) state that in some countries such as the United States, Japan, and 
Germany, the law protects the rights of at least some investors and the courts are relatively willing to enforce these laws. But even in these countries, the legal system leaves managers and controlling owners with considerable discretion to manage reported earnings in order to mask true firm performance and to conceal their private control benefits from outsiders. In most of the rest of the world, the extent of investor protection is less protective and courts function less well as they consider only the clearest violations of investor rights. As a result, legal protection alone becomes insufficient and accounting information such as earnings cannot reflect the "true" economic performance.

The quality of reported earnings in a country could be low because of a complex interaction among managerial motivation, accounting standards, and investor protection. For example, managers are motivated to manipulate earnings, and they can do this either because accounting standards allow substantial flexibility, accounting standards do not exist to specify accounting principles related to some areas of business activity, or accounting standards, though rigorous, are weakly enforced (Bhattacharya et al. 2003). The level of investor protection and the quality of enforcement differ greatly and systematically across countries. Part of these differences in investor protections cause differences in the nature and effectiveness of financial systems around the world (La Porta et al. 1997). Bushman and Smith (2001) document that laws can protect investors from expropriation by corporate insiders. Thus, earnings quality around the world could vary based on the differences in investor protection and the quality of enforcement. This study hypothesizes that high earnings quality should be found in firms from countries with high investor protection. 
Previous research related to a linkage between investor protection and earnings quality is relatively scarce. Most related studies have focused on the effect of investor protection on earnings management (Leuz et al 2003), value relevance of earnings (Ali and Hwang 2000; Hung 2001), and informativeness of reported earnings (Ball at el. 2000). Leuz et al. (2003) find less earnings management in countries with stronger investor protection. Bhattacharya et al. (2003) find that an increase in overall earnings opacity in a country is linked to an increase in the cost of equity and a decrease in trading in the stock market of that country. Ali and Hwang (2000) document that earnings in the U.S. is more value relevant than earnings in other countries because of the differences in country-specific factors. Hung (2001) concludes that shareholder protection improves the effectiveness of accrual accounting. Ball et al. (2000) document that an important difference between common law and code law countries is the manner of resolving information asymmetry between managers and potential users of accounting income, including debt and equity investors, employees, suppliers and customers. These prior studies show the importance of an individual country's investor protection on the quality of accounting information. However, they focus on one aspect of earnings attributes ${ }^{11}$ such as earnings smoothness or value relevance of earnings. Hence, this study extends prior research by examining four accounting-based earnings attributes and exploring the effect of investor protection on the quality of earnings (proxied by these four earnings attributes) across countries.

\footnotetext{
11 Francis et al. (2004) examine seven earnings attributes: accruals quality, persistence, predictability, smoothness, value relevance, timeliness, and conservatism. They characterize the first four attributes as accounting-based because they are typically measured using accounting information only. The last three attributes were characterized as market-based because proxies for these constructs are typically based on relations between market data and accounting data. This study employs the first four earnings attributes.
} 


\subsection{Purpose of the Study}

The purpose of this study is to examine the linkage between investor protection and reported earnings quality. Establishing such a link provides evidence of the role of investor protection in improving earnings quality. Research on a linkage between investor protection and earnings quality is beneficial. First, a financial reporting system supported by strong governance, high quality standards, and sound regulatory framework is a key to economic development (Wong 2004). High earnings quality reduces the risk to shareholders, creditors, and others contracting with the firm and plays an integral role in contributing to a country's economic growth and financial stability. Second, differences in legal institutions can affect the usefulness of accounting income numbers. For example, one reason why the usefulness of earnings and the role of earnings in firm valuation may not generalize internationally relates to the differences in earnings quality as affected by these differences.

\subsection{Contribution}

This study contributes to the accounting literature in the following ways. First, prior research has focused on cross-country differences in the properties of earnings (e.g., Alford et al. 1993; Ball et al. 2003; Ali and Hwang 2000) using one aspect of earnings attributes. This study is one of the first to explore cross-country differences in the properties of reported earnings using four accounting-based earnings attributes to draw conclusions about earnings quality. Second, this study extends prior studies such as DeFond et al. (2004), Ashbaugh and LaFond (2003), Leuz et al. (2003), Bhattacharya et al. (2003), Hung (2001), Ball et al. (2000), and Ali and Hwang (2000) by investigating 
the effects of investor protection on accounting-based earnings attributes and earnings quality. Finally, the findings of this study have implications for security analysts, regulators, standard setters, and other accounting information users in enhancing their understanding of legal institutional differences and their impact on the properties of reported earnings. 


\section{CHAPTER 2}

\section{REVIEW OF LITERATURE}

Previous research related to the effects of legal protection of investors on accounting-based earnings attributes is relatively rare. There are some recent studies using individual countries as the unit of analysis to examine the effects of certain legal institutional variables on (1) earnings management (Leuz et al. 2003; Ashbaugh and LaFond 2003; Fulkerson et al. 2004; Haw et al. 2004), (2) value relevance of earnings and book value of equity (Ali and Hwang 2000; Hung 2001), and (3) informativeness of reported accounting income (Ball at el. 2000, 2003; Defond et al. 2004). Using individual countries as the unit of analysis, this study explores the effects of legal protection of investors on accounting-based earnings attributes and earning quality (captured by these four earnings attributes) across countries. The following are prior accounting related studies involving the legal protection of investors.

\subsection{Foundation of Investor Protection Studies}

Meek and Thomas (2004) indicate that the foundation for accounting related studies involving the legal protection of investors is La Porta et al. (1997, 1998, and 2000). La Porta et al. (1997) use a sample of 49 countries and document that countries with poorer investor protection, measured by both the character of legal rules and the quality of law enforcement, have smaller and narrower capital markets. Using the same 
sample of 49 countries, La Porta et al. (1998) examine legal rules covering protection of corporate shareholders and creditors, the origin of these rules, and the quality of their enforcement. They document that common law countries generally have the strongest and French-civil-law countries the weakest, legal protection of investors, with Germanand Scandinavian-civil-law countries located in the middle. La Porta et al. (2000) describe the differences in laws and the effectiveness of investors' enforcement across countries, discuss the possible origins of these differences, summarize their consequences, and assess potential strategies of corporate governance reform. They argue that the legal approach is a more fruitful way to understand corporate governance and its reform than the conventional distinction between bank-centered and marketcentered financial systems. Recently, La Porta et al. (2004) examine the effect of securities laws on stock market development in 49 countries and find little evidence that public enforcement benefits stock markets, but strong evidence that laws mandating disclosure and facilitating private enforcement through liability rules benefit stock markets.

\subsection{Effects of Institutional Variables on Earnings Management}

Leuz et al. (2003) examine systematic differences in earnings management across 31 countries and find that earnings management decreases in investor protection because strong protection limits insiders' ability to acquire private control benefits, thereby reducing their incentives to mask firm performance. Bhattacharya et al. (2003) construct 
an overall earnings opacity ${ }^{12}$ measure using three dimensions of reported accounting earnings across 34 countries: earnings aggressiveness, loss avoidance, and earnings smoothing. They document that an increase in overall earnings opacity in a country is linked to an economically significant increase in the cost of equity and an economically significant decrease in trading in the stock market of that country. Ashbaugh and LaFond (2003) investigate whether the quality of working capital accruals differs systematically in international markets and whether differences in quality are associated with firmspecific and institutional factors that drive the demand for accounting information. They find that legal environment and the alignment between tax and book reporting are a significant determinants of working capital accruals quality.

Fulkerson et al. (2004) highlight important legal, political, and cultural dimensions along with common law and code law countries and formulate testable hypotheses about how these differences are likely to influence earnings management and earnings quality. Their results indicate that earnings management is lower and earnings quality is higher in common law countries than in code law countries. Haw et al. (2004) examine the role of both legal and extra-legal institutions in limiting income management and document that a common law tradition and an efficient judicial system subsume the effects of the other legal institutions, and that a high rate of tax compliance subsumes the effects of the other extra-legal institutions in curbing insider income management.

\footnotetext{
12

They define the earnings opacity of a country as the extent to which the distribution of reported earnings of firms in that country fails to provide information about the distribution of the true, but unobservable, economic earnings of firms in that country.
} 


\subsection{Effects of Institutional Variables on Value Relevance of Earnings}

Ali and Hwang (2000) explore the relationship between measures of the valuerelevance of financial accounting data and several country-specific factors. They find that value relevance of financial reports is lower for countries where (1) the financial systems are bank-oriented rather than market-oriented, (2) private-sector bodies are not involved in the standard-setting process, (3) accounting practices follow the Continental model as opposed to the British-American model, (4) tax rules have a greater influence on financial accounting measurements, and (5) spending on auditing services is relatively low. Hung (2001) shows that the use of accrual accounting (versus cash accounting) negatively affects the value relevance of financial statements in countries with weak shareholder protection. This negative effect, however, does not exist in countries with strong shareholder protection.

\subsection{Effects of Institutional Variables on Informativeness of Earnings}

Ball et al. (2000) characterize the 'shareholder' governance models of common law countries as resolving information asymmetry by public disclosure while the 'stakeholder' governance model of code law countries resolves information asymmetry through private communication. Accounting income in code law countries is directly linked to current payouts (to employees, managers, shareholders, and governments) and they find that it is less timely, particularly in incorporating economic losses. Their results show that the demand for accounting income in different institutional contexts causes its properties to vary internationally. Guenther and Young (2000) investigate how crosscountry differences in financial accounting standards affect the relation between financial 
accounting earnings and real economic value-relevant events that underlie those earnings. They find that accounting earnings in the UK and the US are more closely related to underlying economic activity than accounting earnings in France and Germany because of (1) differences in legal systems and the demand for accounting information, (2) differences in legal protection for external shareholders, and (3) differences in the degree of tax conformity in their sample countries.

Ball et al. (2003) examine properties of accounting income in four East Asian countries whose standards derive from common law sources (U.K., U.S., and IAS). Using timely recognition of economic income (particularly losses) as a proxy for financial reporting quality, they document that earnings timeliness of these East Asian countries is not higher than that of code law countries. DeFond et al. (2004) examine the information content of annual earnings announcements in 26 countries and find that they are more informative in countries with stronger legal institutions that protect investors' rights. They also document that annual earnings announcements are more informative in countries with higher quality earnings, better enforced insider trading laws, or more value relevant earnings, and that annual earnings' announcements are less informative in countries with more frequent interim financial reporting.

\subsection{Summary}

In sum, prior studies investigate the effects of certain legal institutional variables on earnings management, value relevance of earnings, and informativeness of reported earnings. The value relevance literature examines associations between economic income, measured using equity returns, and accounting numbers such as earnings and 
reveals which countries experience greater associations between accounting numbers and equity returns. The earnings management literature investigates the effect of institutional factors on earnings management across countries. The informativeness of reported earnings literature shows the potential causes of variation in earnings informativeness around the world. However, all of these studies consider only one attribute of earnings such as earnings smoothness. This study explores four attributes of earnings in order to draw a conclusion of earnings quality and show how institutional factors affect the quality of earnings around the world. 


\section{CHAPTER 3}

\section{THEORETICAL SUPPORT}

\subsection{Earnings Attributes Measures}

In this section, four earnings attributes are described with an explanation of how prior research has characterized each attribute. The four earnings attributes are accruals quality, earnings persistence, earnings predictability, and earnings smoothness.

\subsubsection{Accruals Quality}

Several measures to assess earnings quality indicate that earnings which maps more closely into cash is more desirable (e.g. Francis et al. 2004; Penman 2001; Harris et al. 2000). The gap between earnings and cash is from accruals. One role of accruals is to shift or adjust the recognition of cash flows over time so that the adjusted numbers (earnings) better measure firm performance. However, accruals require assumptions and estimates of future cash flows. Thus, accruals are the product of judgments, estimates, and allocations. Dechow and Dichev (2002) (hereafter, DD) develop a measure of accruals quality and argue that the quality of accruals and earnings is decreasing in the magnitude of estimation error in accruals. The DD model uses firm-specific regressions of changes in working capital on last year, present, and one-year ahead cash flows from operations and defines accruals quality as a standard deviation of the residual from this firm-specific regression. 
However, McNichols (2002) proposes a modified Dechow and Dichev (2002)

model, arguing that the changes in sales revenue and property, plant, and equipment are important in forming expectations about current accruals, over and above the effects of operating cash flows. She shows that applying variables from the Jones (1991) model and modified Jones model (Dechow et al. 1995) into the cross-sectional DD model significantly increases its explanatory power and thus reduces measurement error. The accrual estimation errors using a residual $\left(\varepsilon_{t}\right)$ is measured from the following equation:

$$
\begin{aligned}
& \frac{\text { TCA }_{j, t}}{\text { TotalAsset }_{j, t-1}}=b_{0}+b_{1} * \frac{C F O_{j, t-1}}{\text { TotalAsset }_{j, t-1}}+b_{2} * \frac{C F O_{j, t}}{\text { TotalAsset }_{j, t-1}}+b_{3} * \frac{\text { CFO }_{j, t+1}}{\text { TotalAsset }_{j, t-1}} \\
& +b_{4} * \frac{\Delta \text { REV }_{j, t}}{\text { TotalAsset }_{j, t-1}}+b_{5} * \frac{\text { PPE }_{j, t}}{\text { TotalAsset }_{j, t-1}}+\varepsilon_{j, t}
\end{aligned}
$$

Where:

$$
\begin{aligned}
& \mathrm{TCA}_{\mathrm{j}, \mathrm{t}}=\text { Firm } \mathrm{j} \text { 's total current accruals in year } \mathrm{t} \text {. } \\
& =\left(\Delta \mathrm{CA}_{\mathrm{j}, \mathrm{t}}-\Delta \mathrm{CL}_{\mathrm{j}, \mathrm{t}}-\Delta \mathrm{Cash}_{\mathrm{j}, \mathrm{t}}+\Delta \mathrm{STDEBT}_{\mathrm{j}, \mathrm{t}}+\Delta \mathrm{TP}_{\mathrm{j}, \mathrm{t}}\right)_{\text {. }} \text {. } \\
& \text { TotalAsset }_{\mathrm{j}, \mathrm{t}-1}=\text { Firm j's total assets in year t-1 (\#G107). } \\
& \mathrm{CFO}_{\mathrm{j}, \mathrm{t}}=\text { Firm } \mathrm{j} \text { 's cash flow from operations in year } \mathrm{t} \text {. } \\
& \text { This CFO is calculated as net income before extraordinary items } \\
& \text { (\#G378) less total accruals (TA). }{ }^{13} \\
& \triangle \mathrm{REV}_{\mathrm{j}, \mathrm{t}} \quad=\text { Firm } \mathrm{j} \text { 's change in total revenue between year } \mathrm{t}-1 \text { and } \mathrm{t} \text {. } \\
& \mathrm{PPE}_{\mathrm{j}, \mathrm{t}} \quad=\text { Firm } \mathrm{j} \text { 's property, plant, and equipment in year } \mathrm{t}(\# \mathrm{G} 639) \text {. }
\end{aligned}
$$

13

Variable CFO is available as a data item for US firms as it is required by SFAS No. 95, but not for all non-U.S. firms. Consistent with Leuz et al. (2003) and Bhattacharya et al. (2003), this study uses the indirect (balance sheet) approach to estimate accruals rather than the direct (statement of cash flows) approach. Although the indirect approach may suffer from measurement error in accruals, especially for firms with merger and acquisition activity or discontinued operations (Hribar and Collins 2002), it allows this study to calculate accruals for a larger sample of firms across countries (when there are differences in the presentation of cash flow information across countries and time) than is possible in the direct approach. In fact, many of sample countries in this study do not require the preparation or presentation of a statement of cash flows. 


\begin{tabular}{|c|c|}
\hline $\mathrm{TA}_{\mathrm{j}, \mathrm{t}}$ & $\begin{array}{l}=\text { Firm j's total accruals in year } \mathrm{t} \\
=\left(\Delta \mathrm{CA}_{\mathrm{j}, \mathrm{t}}-\Delta \mathrm{CL}_{\mathrm{j}, \mathrm{t}}-\Delta \mathrm{Cash}_{\mathrm{j}, \mathrm{t}}+\Delta \mathrm{STDEBT}_{\mathrm{j}, \mathrm{t}}+\Delta \mathrm{TP}_{\mathrm{j}, \mathrm{t}}-\operatorname{Dep}_{\mathrm{j}, \mathrm{t}}\right)\end{array}$ \\
\hline $\mathrm{CA}_{\mathrm{j}, \mathrm{t}}$ & $=$ Firm j's current assets in year $\mathrm{t}(\# \mathrm{G} 638)$. \\
\hline $\mathrm{CL}_{\mathrm{j}, \mathrm{t}}$ & $=$ Firm j's current liabilities in year $\mathrm{t}(\# \mathrm{G} 650)$. \\
\hline $\operatorname{Cash}_{\mathrm{j}, \mathrm{t}}$ & $=$ Firm j's cash in year $\mathrm{t}(\# \mathrm{G} 628)$. \\
\hline $\mathrm{STDEBT}_{\mathrm{j}, \mathrm{t}}$ & $=$ Firm j's debt in current liabilities in year $\mathrm{t}(\# \mathrm{G} 132)$. \\
\hline $\mathrm{TP}_{\mathrm{j}, \mathrm{t}}$ & $=$ Firm j's taxes payable in year $\mathrm{t}(\# \mathrm{G} 161)$. \\
\hline $\operatorname{Dep}_{\mathrm{j}, \mathrm{t}}$ & $\begin{aligned}= & \text { Firm j’s depreciation and amortization expenses in year } \mathrm{t} \\
& (\# \mathrm{G} 399) .\end{aligned}$ \\
\hline
\end{tabular}

This study employs the modified DD model proposed by McNichols 2002 and assumes that uncertainty in accruals (proxied by standard deviation of the residual) is best captured by this model. The measure of accruals quality is based on this standard deviation of estimated residual ( $\sigma\left(\hat{\varepsilon}_{j, t}\right)$, hereafter, Stdresid) from equation (1) as it refers to the extent to which working capital accruals map into operating cash flow realizations. Large (small) values of Stdresid correspond to lower (higher) accruals quality and lower (higher) earnings quality.

\subsubsection{Earnings Persistence}

Kormendi and Lipe (1987) use firm-level regressions of current earnings on last year's earnings to estimate the slope coefficient estimates of earnings persistence. This study employs the measure in Kormendi and Lipe (1987) and uses the following equation:

$$
\frac{\text { Earn }_{j, t}}{\text { TotalAssets }_{j, t-1}}=\alpha+\delta_{1} * \frac{\text { Earn }_{j, t-1}}{\text { TotalAsset }_{j, t-1}}+v_{j, t}
$$


Where:

$$
\begin{aligned}
& \text { Earn }_{\mathrm{j}, \mathrm{t}}=\text { Firm's j net income before extraordinary items in year t (\#G378). } \\
& \text { Earn }_{\mathrm{j}, \mathrm{t}-1}=\text { Firm's j net income before extraordinary items in year } \mathrm{t}-1 .
\end{aligned}
$$

The measure capturing earnings persistence is based on the slope coefficient estimate $\left(\delta_{1}\right.$, hereafter, Persist) from equations (2). Values of $\delta_{1}$ close to one (or greater than one) indicate highly persistent earnings while values close to zero imply highly transitory earnings. Persistent earnings are viewed as higher quality, while transitory earnings are viewed as lower quality.

\subsubsection{Earnings Predictability}

Lipe (1990) provides a measure of earnings predictability as it is reflected in the variance of the earnings shocks (as variance increases, the predictability decreases). Francis et al. (2004) also follow his study by measuring earnings predictability using the square root of the estimated error variance from the earnings persistence equation. In this study, earnings predictability is calculated using the square root of the error variance from equation (2). Predictability is:

$$
\operatorname{Pred}_{\mathrm{j}, \mathrm{t}}=\sqrt{\sigma^{2}\left(\hat{v}_{j, t}\right)}
$$

Where:

$$
\begin{aligned}
\operatorname{Pred}_{\mathrm{j}, \mathrm{t}}= & \text { Firm } \mathrm{j} \text { 's earnings predictability in year } \mathrm{t} \text {, captured by the square } \\
& \text { root of the error variance from equation }(2) . \\
\sigma^{2}\left(\hat{v}_{j, t}\right)= & \text { Estimated error variance of firm } \mathrm{j} \text { in year } \mathrm{t} \text {, calculated from } \\
& \text { equation }(2) .
\end{aligned}
$$


Large (small) values of Pred imply less (more) predictable earnings. More predictable earnings are viewed as higher quality, while less predictable earnings are viewed as lower quality.

\subsubsection{Earnings Smoothness}

Wysocki (2004) suggests a measure of earnings quality using closeness-to-cash as a benchmark because it provides a direct benchmark for the absolute magnitude of "economic income." He states that while discretionary accruals models control for firm and industry characteristics, they fail to identify a benchmark for the underlying "economic income" that is being managed. Leuz et al. (2003) and Burgstahler et al. (2004) suggest a possible solution to this problem by introducing a closeness-to-cash benchmark for underlying "economic income" using absolute working capital accruals as a measure of earnings management and then scaling this measure by absolute cash flow from operations. They also define earnings smoothness as the ratio of the firm-level standard deviations of operating income and operating cash flow (both scaled by lagged total assets). Bowen et al. (2003) measure earnings smoothness as the standard deviation of operating cash flows divided by the standard deviation of earnings. Similarly, Francis et al. (2004) measure earnings smoothness as the ratio of firm j's standard deviation of net income before extraordinary items divided by beginning total assets, to its standard deviation of cash flow operations divided by beginning total assets.

Following Bowen et al. (2003), this study measures earnings smoothness as the ratio of the firm-level standard deviation of operating cash flows to the standard deviation of earnings (both scaled by beginning total assets). This measure is also similar to the 
one found in Hunt et al. (1997), Leuz et al. (2003), Pincus and Rajgopal (2002), and Francis et al. (2004).

$$
\text { Smooth }_{\mathrm{j}, \mathrm{t}}=\frac{\sigma\left(\mathrm{CFO}_{j, t} / \text { TotalAssets }_{j, t-1}\right)}{\sigma\left(\text { Earn }_{j, t} / \text { TotalAssets }_{j, t-1}\right)}
$$

Where:

$$
\begin{array}{ll}
\text { Smooth }_{\mathrm{j}, \mathrm{t}}= & \text { Firm } \mathrm{j} \text { 's earnings smoothness in year } \mathrm{t} . \\
\sigma & =\text { Firm } \mathrm{j} \text { 's standard deviation } \\
\mathrm{CFO}_{\mathrm{j}, \mathrm{t}} & \text { Firm } \mathrm{j} \text { 's operating cash flows in year } \mathrm{t} \text { (indirect approach) } \\
\sigma\left(\text { Earn }_{\mathrm{j}, \mathrm{t}}\right) & = \\
& \text { Firm } \mathrm{j} \text { 's net income before extraordinary items in year } \mathrm{t} \\
& (\# \mathrm{G} 378) .
\end{array}
$$

Ratios in excess one indicate more variability in operating cash flows relative to the variability of earnings, which implies the use of accruals to smooth earnings. Thus, large (small) values of Smooth indicate more (less) earnings smoothness and low (high) earnings quality.

\subsection{Investor Protection Measures}

This study employs eight institutional characteristics from La Porta et al. (1997, 1998, 2004) and defines them as investor protection proxies: (1) antidirector rights, (2) efficiency of the judicial system, (3) rule of law, (4) corruption index, (5) ratio of the stock market capitalization held by minorities to gross domestic product, (6) ratio of the number of domestic firms to the population, (7) ratio of the number of initial public offerings of equity to the population, and (8) ownership concentration. La Porta et al. (1998) use proxies 2, 3, and 4 to measure the level of legal enforcement in different countries. Leuz et al. (2003) use proxies 5, 6, and 7 to proxy the importance of equity 
markets across countries. However, this study considers these proxies individually and uses them to characterize the sample countries into three distinct clusters using K-means cluster analysis. Table 2 presents eight investor protection proxies of the sample countries. The following sections explain how prior research has characterized these eight proxies.

\subsubsection{Antidirector Rights}

Following La Porta et al. (1998), this study defines antidirector rights using an index aggregating shareholder rights. This index is formed by adding 1 when (1) the country allows shareholders to mail their proxy vote to the firm, (2) shareholders are not required to deposit their shares prior to the general shareholders' meeting, (3) cumulative voting or proportional representation of minorities in the board of directors is allowed, (4) an oppressed minorities mechanism is in place, (5) the minimum percentage of share capital that entitles a shareholder to call for an extraordinary shareholders' meeting is less than or equal to 10 percent (the sample median), or (6) shareholders have preemptive rights that can be waived only by shareholders' vote. The index ranges from zero to six, with higher scores implying stronger antidirector rights and better investor protection.

\subsubsection{Law Enforcement: Efficiency of Judicial System}

Based on La Porta et al. (1998, 2000, 2004), efficiency of the judicial system is an index representing the average of investors' assessment of conditions of the judicial 
system in each country between 1980 and 1983. The index ranges from 0 to 10 , with higher scores implying greater legal enforcement and better investor protection ${ }^{14}$.

\subsubsection{Law Enforcement: Rule of Law}

Based on Kaufmann et al. (2004) and La Porta et al. (2004), rule of law is an index representing the extent to which agents have confidence in and abide by the rules of society in year 2000. These include perceptions of the incidence of both violent and non-violent crime, the effectiveness and predictability of the judiciary, and the enforceability of contrasts. This estimate ranges from -2.5 to 2.5 , with higher scores implying greater legal enforcement and better investor protection.

\subsubsection{Law Enforcement: Corruption Index}

Based on Kaufmann, et al. (2004) and La Porta, et al. (2004), corruption index is an index measuring the exercise of public power for private gain in year 2000. This index captures aspects ranging from the frequency of additional payments to get things done to the effects of corruption on the business environment. The index ranges from -2.5 to 2.5 , with higher scores implying greater legal enforcement and better investor protection.

\subsubsection{Importance of Equity Market: External Cap/GDP Ratio}

Based on La Porta et al. (2004), External Cap/GDP ratio is the ratio of the stock market capitalization held by minorities to gross domestic product for the period of

\footnotetext{
14

Source: International Country Risk Guide.
} 
1996 - 2000. The stock market capitalization held by minorities is computed as the product of the aggregate stock market capitalization and the average percentage of common shares not owned by the top three shareholders in the ten largest non-financial, privately-owned domestic firms in a given country. ${ }^{15}$ This study uses this ratio to measure the importance of the equity market in each country, with higher values indicating the greater importance of the stock market and better investor protection.

\subsubsection{Importance of Equity Market: Domestic Firms/Pop Ratio}

Based on La Porta et al. (2004), Domestic Firms/Pop ratio is the ratio of the number of domestic firms listed in a given country to its population (in millions) for the

period of 1996-2000. ${ }^{16}$ This study uses this ratio to measure the importance of the equity market in each country, with higher values indicating the greater importance of the stock market and better investor protection.

\subsubsection{Importance of Equity Market: IPOs/GDP Ratio}

Based on La Porta et al. (2004), IPOs/GDP ratio is the ratio of equity issued by newly-listed firms in a given country (in thousands) to its gross domestic product (in millions) for the period of 1996-2000. ${ }^{17}$ This study uses this ratio to measure the importance of the equity market in each country, with higher values indicating the greater importance of the stock market and better investor protection.

\footnotetext{
15

Source: La Porta et al. (1999), Hartland-Peel (1996) for Kenya, Bloomberg and various annual reports for Ecuador, Jordan, and Uruguay. 16

Source: International Finance Corporation: Emerging Market Database (2001) and World Bank (2001).

17

Source: Securities Data Corporation, World Bank (2001).
} 


\subsubsection{Ownership Concentration}

Following La Porta et al. (2004), the ownership concentration is measured as the average percentage of common shares owned by the top three shareholders in the ten largest non-financial, privately-owned domestic firms in a given country. A firm is considered privately owned if the State is not a known shareholder in it. ${ }^{18}$ This average percentage of each country indicates a country's ownership concentration, with lower values reflecting better investor protection.

18

Source: La Porta et al. (1999), Hartland-Peel (1996) for Kenya, Bloomberg and various annual reports for Ecuador, Jordan, and Uruguay. 


\section{CHAPTER 4}

\section{STATEMENT OF HYPOTHESES}

This chapter develops hypotheses related to the linkage between investor protection and various measures of earnings quality. Figure 1 presents eight institutional characteristics believed to affect each of the earnings attributes in both U.S. and non-U.S. firms. With this relationship, this study hypothesizes that firms with the least favorable values of each earnings attribute generally occur in countries whose institutional characteristics provide weaker protection of investors than in countries with stronger investor protection. The first hypothesis stated in alternative form is:

H1: Firms with the least favorable values of each earnings attribute (considered individually) generally occur in countries whose institutional characteristics provide weaker protection of investors than in countries with stronger investor protection.

The next step is based on what this study finds in hypothesis 1 . If the results of hypothesis 1 are consistent across each of the earnings attributes (i.e., all four earnings attributes are high quality in countries whose institutional characteristics provide stronger investor protection), the next step is described in Section 4.1. If the findings of hypothesis 1 are mixed (i.e., countries whose institutional characteristics provide stronger investor protection have both favorable and unfavorable values for some of their earnings attributes), the next step is described in Section 4.2 . 


\subsection{Results of H1 Are Consistent Across Four Earnings Attributes}

If results of hypothesis 1 are consistent across each of the four earnings attributes, this study will construct an overall summary measure of earnings quality and use this summary measure to draw a conclusion of earnings quality across sample countries. This

summary is called an aggregate earnings quality measure and is computed by averaging the country rankings for the four individual earnings attributes. Earnings quality is expected to be lower in countries whose institutional characteristics provide weaker investor protection. And, the potential hypothesis 2 stated in alternative form is:

H2: Earnings quality (captured using aggregate earnings quality score) is expected to be lower in countries whose institutional characteristics provide weaker protection of investors than in countries with stronger investor protection.

\subsection{Results of H1 Are Mixed Across Four Earnings Attributes}

If results of hypothesis 1 are mixed across each of the four earnings attributes, this study will consider each of the earnings attributes individually since conclusions about earnings quality and investor protection depend on how earnings quality is defined.

Thus, this study will focus more on how each of the investor protection variables affects each of the earnings attributes and examine only hypothesis 1. 


\section{CHAPTER 5}

\section{DATA AND SAMPLE SELECTION}

This study selects all firm-year observations in all countries that have the required financial data to estimate all empirical models in this study. All data are from the Global Vantage Industry Research and Industry Active Files for the fiscal years 1994 to 2003. Since the accounting quality model 1 requires changes in working capital and past and future cash flows from operations to estimate total accruals, this restricts the sample period of this study to the period 1996 to 2002. This study restricts the sample to industrial firms and excludes all firms with SIC codes 6000-6999 and 9000-9999, as in Barth et al. (1999), Leuz et al. (2003), and Burgstahler et al. (2004). This restriction is used to exclude banks and financial institutions and to increase the homogeneity of the sample and the comparability of the results across countries.

Following La Porta (1997, 1998, and 2000), this study begins with the same 49 countries as in these studies and eliminates countries with fewer than 200 firm-year observations to compute each of the firm-level variables in the analysis. Each firm must have income statement and balance sheet information for at least three consecutive years. 
Finally, this study trims the top and bottom 1 percent of the sample with respect to change in total assets, total current accruals, and change in net income before extraordinary items. ${ }^{19}$ These restrictions result in a final sample of 57,610 firm-year observations drawn from 31 countries.

Since this study's goal is to examine the impact of country-level institutions on each of four accounting-based earnings attributes, this study assigns firm-year observations to countries based on Global Vantage Database's country code of incorporation (CINC). ${ }^{20}$ Table 1, Panel A shows all firm-year observations for each legal origin over the same period of this study. The first and second highest firm-year observations are from "English" and "German" legal origin countries (44.3 percent and 37.6 percent, respectively). Table 1, Panel B presents the final sample of 31 countries over the period 1996-2002. Nearly 55.7 percent of the sample consists of firm-year observations from United Kingdom (3,230 observations), Japan (16,461 observations), and the United States (12,380 observations). ${ }^{21}$

As noted previously, this study employs eight investor protection variables based on La Porta et al. (2004) and Kaufmann et al. (2004). Since most of the variables are available for the period of 1996-2000, this study estimates investor protection variables

\footnotetext{
19 20 All accounting variables are scaled by lagged total assets.

Classifying firms on the basis of their country of incorporation in Global Vantage Database assumes that home-country institutions are expected to have the strongest influence on observed earnings attributes. However, this assumption may introduce a bias into the study since firms engaged in cross-border product or financial transactions could also be influenced by the institutions of those additional countries. To that extent, cross-border transactions are expected to diminish the power of this study's tests. 21

When a study's tests are based on pooled firm-year observations, the dominance of these observations, as well as their strong correlation with code/common law institutional distinctions, could affect a study's primary tests. However, this study should not be affected because the research design is based on pooled results of firm-year observations per country per year, consistent with most country-year investor protection observations.
} 
for the period of 2001 and 2002 using the 2000 data. $^{22}$ Table 2 shows the average values of each investor protection variables across 31 countries over the period of 1996 to 2002 .

22

The values of antidirector rights as reported in La Porta et al. (1998) are the 1998 values and the same across the eight years 1996-2002. The values of efficiency of judicial system as reported in La Porta et al. (2004) are the 1980-83 values and the same across the eight years 1996-2002. The values of rule of law as reported in La Porta et al. (2004) are the 2000 values and the same across the eight years 1996-2002. The values of corruption index as reported in Kaufmann et al. (2004) and La Porta et al. (2004) are the 2000 values and the same across the eight years 1996-2002. The values of ownership concentration as reported in La Porta et al. (2004) are the 1999 values are the same across the eight years 1996-2002. The rest of the variables are data per country per year from the period of 1996-2000. By using data from prior studies, an unavoidable limitation of this study is that some of these particular investor protection measures are constant over the test period. 


\section{CHAPTER 6}

\section{RESEARCH DESIGN}

\subsection{K-means Cluster and Correlation Analyses}

This study takes the following steps to test hypothesis 1 . First, a K-means cluster analysis based on MacQueen (1967) is used to group countries by their level of investor protection, based on the institutional characteristics discussed earlier. ${ }^{23}$ Second, each of the four earnings attributes is measured for the companies in the sample using a pooled regression per country per year in order to get 217 country-year accounting observations, calculated from a product of 31 countries and 7 years. These 217 country-year earnings attribute observations are then averaged by country. Then, this country mean value is assigned to its investor protection cluster. Based on hypothesis 1, the study hypothesizes that clusters with lower levels of investor protection should have the least favorable values of these attributes, and vice-versa. ${ }^{24}$ To test hypothesis 1 , this study uses Kmeans cluster and correlation analyses to see whether the least (most) favorable values of each earnings attribute generally occur in countries whose institutional characteristics provide weaker (stronger) investor protection.

\footnotetext{
23 K-means clustering is one of the simplest unsupervised learning algorithms that solves the clustering problem by classifying a given data set into a certain number of clusters. The algorithm is composed of the following steps: (1) place K points into the space represented by the objects that are being clustered, (2) assign each object to the group that has the closest centroid, (3) recalculate the positions of the K centroids when all objects have been assigned, (4) repeat Steps 2 and 3 until the centroids no longer move. 24

Least favorable values of the four earnings attributes are low accruals quality, low earnings persistence, less predictable earnings, and high earnings smoothness.
} 
If the results of hypothesis 1 are consistent across all four earnings attributes, this study will rank each of the earnings attributes across countries and use these ranks to form an aggregate earning quality (EQ) score. As before, each country's aggregate earnings quality score is then assigned to that country's investor protection cluster. Clusters with lower levels of investor protection should have lower earnings quality, and vice-versa.

If the results of hypothesis 1 are mixed across each of the four earnings attributes, this study considers each earnings attribute and makes a conclusion of earnings quality based on how earnings quality is individually defined. Thus, this study will focus more on how each investor protection variable affects each of the earnings attributes rather than an aggregate earnings quality score.

\subsection{Regression Analysis}

This study also uses regression analysis to examine the effect of investor protection on each earnings attribute and if the results of hypothesis 1 are consistent, the aggregate earnings quality score. A control variable for public enforcement is included since it has an impact on earnings attributes (Bushman and Piotroski 2005).

\subsubsection{Results of H1 Are Consistent Across Four Earnings Attributes}

This study uses regression analysis to examine the relation between each of the earnings attributes and investor protection and between aggregate earnings quality measure and investor protection as follows: 


$$
\begin{aligned}
& \mathrm{EQ}_{\mathrm{k}, \mathrm{t}}=\alpha+\beta_{1} \text { AntidirectorRights }_{j i}+\text { ControlVariable }_{j i}+\varepsilon_{j t} \\
& \mathrm{EQ}_{\mathrm{k}, \mathrm{t}}=\alpha+\beta_{1} \text { JudicialSystem }_{j i}+\text { ControlVariable }_{j i}+\varepsilon_{j t} \\
& \mathrm{EQ}_{\mathrm{k}, \mathrm{tt}}=\alpha+\beta_{1} \text { RuleofLaw }_{j i}+\text { ControlVariable }_{j i}+\varepsilon_{j t} \\
& \mathrm{EQ}_{\mathrm{k}, \mathrm{tt}}=\alpha+\beta_{1} \text { Corruption }_{j i}+\text { ControlVariable }_{j i}+\varepsilon_{j t} \\
& \mathrm{EQ}_{\mathrm{k}, \mathrm{t}}=\alpha+\beta_{1} \text { ExternalCap }_{j i}+\text { ControlVariable }_{j i}+\varepsilon_{j t} \\
& \mathrm{EQ}_{\mathrm{k}, \mathrm{tt}}=\alpha+\beta_{1} \text { DomesticFirms }_{j i}+\text { ControlVariable }_{j i}+\varepsilon_{j t} \\
& \mathrm{EQ}_{\mathrm{k}, \mathrm{t}}=\alpha+\beta_{1} \text { IPOs }_{j i}+\text { ControlVariable }_{j i}+\varepsilon_{j t} \\
& \mathrm{EQ}_{\mathrm{k}, \mathrm{t}}=\alpha+\beta_{1} \text { Ownership }_{j i}+\text { ControlVariable }_{j i}+\varepsilon_{j t} \\
& \mathrm{EQ} \mathrm{Score}_{\mathrm{jt}}=\alpha+\beta_{1} \text { AntidirectorRights }_{j i}+\text { ControlVariable }_{j i}+\varepsilon_{j t}
\end{aligned}
$$

Where:

$$
\begin{aligned}
& \mathrm{EQ}_{\mathrm{k}, \mathrm{jt}} \quad=\text { Dimension of earnings attributes }(\mathrm{k}=1,2,3,4) \\
& \mathrm{EQ}_{1, \mathrm{jt}} \quad=\text { Country j's accruals quality rank variable at time } \mathrm{t} \text {. } \\
& \mathrm{EQ}_{2, \mathrm{jt}} \quad=\text { Country j's earnings persistence rank variable at time } \mathrm{t} \text {. } \\
& \mathrm{EQ}_{3, \mathrm{jt}}=\text { Country j's earnings predictability rank variable at time } \mathrm{t} \text {. } \\
& \mathrm{EQ}_{4, \mathrm{jt}} \quad=\text { Country } \mathrm{j} \text { 's earnings smoothness rank variable at time } \mathrm{t} \text {. } \\
& \text { EQ Score }_{\mathrm{jt}} \quad=\text { Country j's aggregate earnings quality rank variable at } \\
& \text { time t. }
\end{aligned}
$$


Control Variable $_{\mathrm{jt}}=$ Country j's public enforcement. This variable is measured at the country level as the mean of four underlying indices: Supervisor Characteristics index, Investigative Powers index, Orders index, and Criminal index. The variable is ranked between 0 (weak public enforcement) to 1 (strong public enforcement) based on La Porta et al. (working paper, 2004).

Public enforcement variable is included to control for the impact of public enforcement on earnings attributes. Bushman and Piotroski (2005) find that stronger public enforcement aspects of securities law discourage "optimism” by slowing recognition of good news in earnings relative to firm in countries with weak public enforcement aspects. Thus, this study includes the public enforcement variable as a control variable for all equations.

The values of coefficient estimate $\left(\beta_{1}\right)$ estimate the magnitude of the impact of an investor protection variable on an earnings attribute or the overall earnings quality score. Based on hypotheses 1 , this study expects positive signs of $\beta_{1}$ for earnings persistence (captured by "Persist") and the first seven investor protection variables and negative signs for earnings persistence and the eighth investor protection variable. The study expects negative signs of $\beta_{1}$ for earnings smoothness (captured by "Smooth"), accruals quality (captured by "Stdresid”), and earnings predictability (captured by "Pred") and the first seven investor protection variables. Positive signs are expected for these three earnings attributes and the eighth investor protection variable. 
6.2.2 Results of H1 Are Mixed Across Four Earnings Attributes

This study uses regression analysis to examine the relation between each of the earnings attributes and investor protection as follows:

$$
\begin{aligned}
& \mathrm{EQ}_{\mathrm{k}, \mathrm{jt}}=\alpha+\beta_{1} \text { AntidirectorRights }_{j i}+\text { ControlVariable }_{j i}+\varepsilon_{j t} \\
& \mathrm{EQ}_{\mathrm{k}, \mathrm{jt}}=\alpha+\beta_{1} \text { JudicialSystem }_{j i}+\text { ControlVariable }_{j i}+\varepsilon_{j t} \\
& \mathrm{EQ}_{\mathrm{k}, \mathrm{jt}}=\alpha+\beta_{1} \text { RuleofLaw }_{j i}+\text { ControlVariable }_{j i}+\varepsilon_{j t} \\
& \mathrm{EQ}_{\mathrm{k}, \mathrm{jt}}=\alpha+\beta_{1} \text { Corruption }_{j i}+\text { ControlVariable }_{j i}+\varepsilon_{j t} \\
& \mathrm{EQ}_{\mathrm{k}, \mathrm{t}}=\alpha+\beta_{1} \text { ExternalCap }_{j i}+\text { ControlVariable }_{j i}+\varepsilon_{j t} \\
& \mathrm{EQ}_{\mathrm{k}, \mathrm{jt}}=\alpha+\beta_{1} \text { DomesticFirms }_{j i}+\text { ControlVariable }_{j i}+\varepsilon_{j t} \\
& \mathrm{EQ}_{\mathrm{k}, \mathrm{jt}}=\alpha+\beta_{1} \text { IPOs }_{j i}+\text { ControlVariable }_{j i}+\varepsilon_{j t} \\
& \mathrm{EQ}_{\mathrm{k}, \mathrm{jt}}=\alpha+\beta_{1} \text { Ownership }_{j i}+\text { ControlVariable }_{j i}+\varepsilon_{j t}
\end{aligned}
$$

Where:

$$
\begin{array}{ll}
\mathrm{EQ}_{\mathrm{k}, \mathrm{jt}} & =\text { Dimension of earnings attributes }(\mathrm{k}=1,2,3,4) \\
\mathrm{EQ}_{1, \mathrm{jt}} & =\text { Country j's accruals quality rank variable at time } \mathrm{t} . \\
\mathrm{EQ}_{2, \mathrm{jt}} & \text { Country j's earnings persistence rank variable at time t. } \\
\mathrm{EQ}_{3, \mathrm{jt}} & \text { Country j's earnings predictability rank variable at time t. } \\
\mathrm{EQ}_{4, \mathrm{jt}} & \text { Country j's earnings smoothness rank variable at time t. } \\
\text { Control variable }_{\mathrm{jt}}= & \text { Country j's public enforcement. This variable is } \\
& \text { measured at the country level as the mean of four } \\
& \text { underlying indices: Supervisor Characteristics index, } \\
& \text { Investigative Powers index, Orders index, and Criminal } \\
& \text { index. The variable is ranked between 0 (weak public } \\
& \text { enforcement) to 1 (strong public enforcement) based on } \\
& \text { La Porta et al. (working paper, 2004). }
\end{array}
$$


In sum, this study examines hypothesis 1 using cluster/correlation and regression analyses. Hypothesis 1 is examined using individual earnings attributes measures. If the results of hypothesis 1 are consistent, hypothesis 2 is examined using an aggregate earnings quality score and based on cluster/correlation analysis and regression analysis. 


\section{CHAPTER 7}

\section{RESULTS}

This chapter presents results of the study. Sections 7.1 and 7.2 discuss descriptive statistics and the cluster analysis of institutional characteristics and earnings attributes, respectively. Section 7.3 provides Pearson (Spearman-rank) correlation matrix between raw (rank) data of earnings attributes and investor protection variables. Regression analysis and sensitivity tests are presented in Sections 7.4 and 7.5, respectively. Section 7.6 summarizes the findings in this study.

\subsection{Descriptive Statistics}

This section provides descriptive statistics for both institutional characteristics and earnings attributes. Section 7.1.1 presents descriptive statistics of institutional variables. Section 7.1.2 presents descriptive statistics of earnings attributes variables.

\subsubsection{Descriptive Statistics: Institutional Characteristics}

Table 2, Panel A provides descriptive statistics on the institutional characteristics of each sample country. These investor protection variables are presented using the average values of each institutional variable from 1996 to 2002. Not surprisingly, the highest level of investor protection can be found in most developed countries including 
the United Kingdom, the United States, Australia, Sweden, Canada, Hong Kong, Singapore, and Norway.

Table 2, Panel B presents expected signs between institutional variables. The study expects a positive correlation between the first seven institutional variables and a negative correlation between the eighth variable and other variables. Table 2, Panel C presents correlation coefficients between institutional variables. The Pearson correlation coefficients are presented in the upper half and the Spearman-rank correlation coefficients are presented in the lower half. The results of Table 2, Panel C show that the correlation coefficients between institutional characteristics have signs consistent with the study's expectations. In other words, the results show all positive sigs for correlations between the first seven institutional characteristics and negative signs for correlations between the eighth institutional characteristics (Ownership) and other institutional characteristics.

\subsubsection{Descriptive Statistics: Earnings Attributes}

Table 3, Panel A presents the number of firm-year observations per country and the average values of the main accounting variables used to calculate each of the earnings attributes. These variables are scaled by lagged total assets, consistent with much of the literature using international data (Leuz et al. 2003; Bhattacharya et al. 2003; Wysocki 2005). Table 3, Panel B provides descriptive statistics of the average values of four earnings attributes variables. The raw earnings attributes variables are obtained from earnings attribute measures using the main variables in Table 3, Panel A. The rank earnings attributes variables are obtained from ranking each earnings attribute (raw data) 
across countries. To be consistent across the four earnings attributes, this study ranks earnings persistence in ascending order and the other three attributes in descending order, so that high rank values indicate high earnings quality.

Table 3, Panel C presents expected signs and correlation coefficients between earnings attributes. Again, the Pearson correlation coefficients are presented in the upper half and the Spearman-rank correlation coefficients are presented in the lower half. The results (right-hand side) based on Pearson and Spearman-rank correlations indicate that earnings smoothness (captured by "Smooth") has a negative correlation with accruals quality (captured by "Stdresid") and earnings predictability (captured by "Pred"), which is inconsistent with the study's expectation. The impact of this unexpected result is discussed later in the results sections.

\subsection{Cluster Analysis}

This section provides K-means cluster analysis data for both institutional characteristics and earnings attributes. Section 7.2.1 presents K-means cluster analysis of institutional variables. Section 7.2.2 presents K-means cluster analysis of earnings attributes variables.

\subsubsection{K-Means Cluster Analysis: Institutional Characteristics}

This study uses eight institutional variables to group sample countries with similar institutional characteristics. These proxies are standardized to Z-scores and a K-means cluster analysis with three distinct clusters is conducted. This approach is similar to that 
of Leuz et al. (2003) ${ }^{25}$ except that this study uses the most recent La Porta et al. data (2004) and does not include a disclosure index as it is likely that this index is highly correlated to each country's earnings attributes. Table 4, Panel A reports means of each cluster and tests of differences between clusters. The results show that the first cluster is characterized by extensive outsider rights, strong legal enforcement, larger stock markets, and low ownership concentration. The second and third clusters are characterized by lower outsider rights, weaker legal enforcement, smaller stock markets, and higher ownership concentration. Thus, the first cluster is referred to as "outsider economies" and the other two clusters are referred to as "insider economies", with the distinction that countries in the second cluster have significantly better legal enforcement, larger stock markets, and lower ownership concentration than those in the third cluster.

Table 4, Panel B presents cluster membership of the sample countries across three distinct clusters. Interestingly, all countries (except Sweden) in the first cluster are common law while all countries in the second cluster are code law. This is consistent with the existence of institutional complementarities found in most finance literature. The third cluster consists of both common law and code law countries. Consistent with Ball et al. (2003), Malaysia and Thailand whose standards derive from common law sources (US, UK, and IAS) are placed in the third cluster as their financial reporting quality (captured by timely loss recognition) is not higher than under code law due to the higher incentives of the managers and auditors responsible for the financial statement

25

Leuz et al. (2003) consider the K-means cluster analysis based on nine institutional variables from La Porta et al. $(1997,1998)$. They standardize nine variables to z-scores and use a K-means cluster analysis to classify 31 countries into three distinct country clusters. 
preparation. However, Singapore is still placed in the first cluster, inconsistent with the findings in Ball et al. (2003).

Table 4, Panel C shows that almost all cluster membership of countries (except Malaysia, Norway, South Africa, South Korea, Spain, and Sweden) in this study is similar to that of Leuz et al. (2003). The difference in cluster membership of this study and that of Leuz et al. (2003) may reflect the developments of countries' investor protection level as their investor protection proxies increased or decreased. For example, Sweden moved from Cluster 2 to Cluster 1, South Korea and Spain moved from Cluster 3 to Cluster 2, Malaysia stepped down from Cluster 1 to Cluster 3, and the other two countries stepped down to the next lower cluster level from the period in Leuz et al. (2003) to the period in this study.

\subsubsection{K-Means Cluster Analysis: Earnings Attributes}

Table 5 presents mean values of rank data of four accounting based-earnings attributes across three distinct clusters based on a k-means cluster analysis. Table 5, Panels A1-A4 report the cluster membership for the 31 sample countries based on cluster analysis performed on the investor protection proxies in Table 2. Countries in each cluster are sorted by the mean-rank scores of accruals quality for Panel A1, earnings persistence for Panel A2, earning predictability for Panel A3, and earnings smoothness for Panel A4. Table 5, Panel B reports the means by cluster based on raw and rank data of each earnings attribute.

Table 5, Panel A1 provides the rankings of accruals quality across 31 countries of the three clusters this study identifies. Japan (29.57) has the highest average accruals 
quality score, followed by Chile (28.71), Mexico (27.00), Brazil (25.86), Italy (23.57), Switzerland (24.00), India (21.57), and Austria (22.43). These countries represent the country sample with high earnings quality. Interestingly, most of these countries are not members of Cluster 1, but members of Clusters 2 and 3. Indonesia (4.00), Germany (4.14), Australia (5.00), USA (7.57), Norway (7.71), Sweden (8.57), and Hong Kong (9.00) show the lowest average accruals quality score in the sample. Most of these countries are from Cluster 1 . The results based on mean-rank accruals quality score contradict hypothesis 1 .

Table 5, Panel A2 provides the rankings of earnings persistence across 31 countries of the three clusters this study identifies. India (25.86) has the highest average earnings persistence score, followed by Netherlands (22.14), USA (22.14), Finland (20.43), Taiwan (20.43), Chile (19.86), Greece (19.43), and Sweden (18.71). These countries represent the country sample with high earnings quality. Hong Kong (6.57), Australia (8.86), South Africa (9.43), Mexico (10.43), Norway (10.86), and Austria (11.71) show the lowest average earnings persistence score in the sample. No particular patterns by cluster are revealed for earnings persistence. The results based on mean-rank earnings persistence score contradict hypothesis 1 since the results are mixed across clusters.

Table 5, Panel A3 provides the rankings of earnings predictability across 31 countries of the three clusters this study identifies. Japan (30.57) has the highest average earnings predictability score, followed by India (27.00), Chile (25.86), Greece (23.14), Switzerland (22.86), Spain (22.86), Italy (22.00), and Brazil (21.71). These countries represent the country sample with high earnings quality. Interestingly, most of these 
countries are not members of Cluster 1, but members of Clusters 2 and 3. Norway (3.29), Australia (3.57), USA (3.71), Hong Kong (5.71), Canada (6.43), UK (8.57), and Sweden (9.43) show the lowest average earnings predictability score in the sample. Again, most of these countries are from Cluster 1 and the results based on mean-rank earnings predictability score contradict hypothesis 1 .

Table 5, Panel A4 provides the rankings of earnings smoothness across 31 countries of the three clusters this study identifies. The United States (29.00) has the highest average mean-rank earnings smoothness score, followed by UK (26.14), Canada (23.86), Hong Kong (23.57), Norway (23.14), Australia (21.43), and Sweden (21.14). ${ }^{26}$ These countries represent the country sample with high earnings quality. Interestingly, most of these countries are members of Cluster 1. Greece (6.14), Spain (6.14), Italy (7.57), Japan (9.00), South Korea (9.43), and Chile (12.43) show the lowest average earnings smoothness score in the sample. All of these countries are from Clusters 2 and 3. The results based on mean-rank earnings smoothness are consistent with hypothesis 1 .

Table 5, Panel B presents mean values of the four accounting based-earnings attributes across three distinct clusters based on a K-means cluster analysis. The results based on raw data show that the first cluster is characterized by low accruals quality, low predictive ability of earnings, and low earnings smoothness. The second and third clusters are characterized by high accruals quality, high predictive ability of earnings, and high earnings smoothness. Both raw and rank data indicate that mean values of all

26

To receive the average ranking (or mean-rank) of a country's earnings smoothness scores, this study uses all seven rank time-series earnings smoothness scores of a country and takes the average of these scores to receive the average ranking of a country's earnings smoothness scores. For instance, the United States is ranked $30^{\text {th }}$ in $1996,31^{\text {st }}$ in $1997,28^{\text {th }}$ in $1998,30^{\text {th }}$ in $1999,31^{\text {st }}$ in $2000,28^{\text {th }}$ in 2001 , and $25^{\text {th }}$ in 2002 based on its earnings smoothness raw scores. As a result, the average ranking of earnings smoothness scores of the United States is 29. 
earnings attributes (except earnings persistence) in Cluster 1 are statistically different from those in Clusters 2 and 3. However, there is no statistical difference between mean values of each earnings attribute in Cluster 2 and those in Cluster 3. For earnings persistence, the results indicate that the mean values of each cluster are not statistically different across clusters implying that there is no effect of differences in institutional characteristics on earnings persistence in each institutional cluster. The results based on the rank data are consistent with those based on the raw data.

In sum, the results based on mean-rank earnings smoothness score are consistent with the theory indicating that countries with high investor protection have less earnings management and high earnings quality. However, the results based mean-rank accruals quality and earnings predictability scores contradict the results based on mean-rank earnings smoothness score. This contradicts the theory and implies that countries with low investor protection have high accruals quality and high earnings predictability. In addition, the results based on mean-rank earnings persistence score do not show any relationship between investor protection and earnings persistence across clusters. In other words, differences in investor protection across countries do not cause differences in earnings persistence across clusters.

\subsection{Correlation Analysis: Earnings Attributes and Institutional Characteristics}

Table 6, Panel A presents expected signs and correlation coefficients between earnings attributes and institutional characteristics based on Spearman-rank correlations. The results of Panel A show that earnings smoothness (captured by "Smooth") is lower 
for countries with high antidirector rights $\left(\mathrm{p}\right.$-value $\left.\mathrm{e}^{27}<.001\right)$, strong judicial system $(\mathrm{p}-$ value $<.001)$, strong rule of law $(\mathrm{p}$-value $=.005)$, low corruption $(\mathrm{p}$-value $=.007)$, strong external capitalization ( $\mathrm{p}$-value $<.001$ ), more domestic firms ( $\mathrm{p}$-value $<.001$ ), more IPOs $(\mathrm{p}$-value $=.004)$, and low ownership concentration $(\mathrm{p}$-value $<.001)$. Interestingly, Panel A shows opposite results for accruals quality and earnings predictability. In other words, the results indicate that accruals quality (captured by "Stdresid") is higher (which means lower accruals quality) for countries with high antidirector rights (p-value $=.063$ ), strong judicial system $(p$-value $=.005)$, strong rule of law $(p$-value $=.013)$, low corruption $(p-$ value $=.007)$, strong external capitalization $(p$-value $=.005)$, more domestic firms $(p-$ value $<.001)$, more IPOs ( $\mathrm{p}$-value $=.004)$, and low ownership concentration $(\mathrm{p}$-value $=$ .081). Similarly, earnings predictability (captured by "Pred") is higher (which means lower predictive ability of earnings) for countries with high antidirector rights ( $\mathrm{p}$-value $=$ $.013)$, strong judicial system $(\mathrm{p}$-value $=.001)$, strong rule of law $(\mathrm{p}$-value $=.004)$, low corruption $(p$-value $=.003)$, strong external capitalization $(p$-value $=.004)$, more domestic firms (p-value $<.001)$, more IPOs ( $p$-value $=.003)$, and low ownership concentration $(\mathrm{p}$-value $=.087)$. In addition, the results present no correlation between earnings persistence (captured by "Persist") and the first seven institutional characteristics. This means that differences in institutional characteristics do not affect differences in earnings persistence across countries, but countries with low ownership concentration appear to have high earnings persistence.

Table 6, Panel B presents expected signs and Spearman-rank correlation coefficients of the four earnings attributes based on rank score and institutional

27

$\mathrm{P}$-values are not reported in the table. 
characteristics. Since the study applies the comparable rank scores across four earnings attributes, the study expects all positive signs between four earnings attributes rank scores and the first seven institutional variables and negative signs between four earnings attributes rank scores and the eighth institutional variables. The results (right-hand side) are consistent with those in Panel A.

In sum, the results of correlation analysis between institutional characteristics and earnings attributes are mixed. If the study defines earnings quality based on earnings smoothness, the results are consistent with the study's hypothesis 1 implying that less earnings smoothness appears to be found in countries whose institutional characteristics are strong (i.e., countries in Cluster 1). However, if the study defines earnings quality based on accruals quality and earnings predictability, the results contradict the hypothesis, indicating that high accruals quality and high predictive ability of earnings appear to be found in countries whose institutional characteristics are weak (i.e., countries in Clusters 2 and 3). Finally, if earnings quality is defined as earnings persistence, the results show no effect of differential institutional characteristics on earnings persistence, except that countries with low ownership concentration appear to have high earnings persistence.

\subsection{Regression Analysis}

The cluster and correlation analyses suggest that earnings smoothness, accruals quality, and earnings predictability are systematically related to a country's institutional characteristics. However, their results are mixed as earnings smoothness (captured by "R_Smooth") is positively related to the first seven institutional variables and negatively 
related to the eighth institutional variable while accruals quality (captured by "R_Stdresid") and earnings predictability (captured by "R_Pred") are negatively related to the first seven institutional variables and positively related to the eighth institutional variable. To strengthen the finding in previous sections, the study uses multiple regressions to examine the relation between earnings attributes (rank score) and institutional variables using the following models:

- $\quad$ Model 1: Earnings attribute $=\mathrm{f}($ InvRights $)+$ control variable

- $\quad$ Model 2: Earnings attribute $=\mathrm{f}($ JudicSys $)+$ control variable

- $\quad$ Model 3: Earnings attribute $=\mathrm{f}($ Ruleoflaw $)+$ control variable

- $\quad$ Model 4: Earnings attribute $=\mathrm{f}($ Corruption $)+$ control variable

- $\quad$ Model 5: Earnings attribute $=\mathrm{f}($ ExtCap $)+$ control variable

- $\quad$ Model 6: Earnings attribute $=\mathrm{f}($ DoFirms $)+$ control variable

- $\quad$ Model 7: Earnings attribute $=$ f (IPOs $)+$ control variable

- $\quad$ Model 8: Earnings attribute $=\mathrm{f}($ Ownership $)+$ control variable

The results of these regression models are presented in Table 7. Table 7, Panel A presents the results based on the association between accruals quality and institutional characteristics. Table 7, Panel B presents the results based on the association between earnings persistence and institutional characteristics. Table 7, Panel C presents results based on the association between earnings predictability and institutional characteristics. The results based on the association between earnings smoothness and institutional characteristics are presented in Table 7, Panel D.

Table 7, Panel A reports multiple regressions between accruals quality rank scores and institutional variables. Inconsistent with hypothesis 1, the results in Panel A indicate 
that accruals quality (captured by "R_Stdresid") is negatively associated with judicial system $(\mathrm{p}<.01)$, rule of law $(\mathrm{p}<.01)$, corruption $(\mathrm{p}<.01)$, and the number of domestic firms $(\mathrm{p}<.05)$. The rank scores of antidirector rights, IPOs, and ownership concentration are not significant. The control variable is significant with the opposite sign of the prediction.

Table 7, Panel B reports multiple regressions between earnings persistence rank scores and institutional variables. Inconsistent with hypothesis 1, the results in Panel B indicate that earnings persistence (captured by "R_Persist") is not associated with most of institutional variables. Only ownership concentration variable is significant $(\mathrm{p}<.01)$ with predicted sign. The control variable is not significant in any model.

Table 7, Panel C reports multiple regressions between earnings predictability rank scores and institutional variables. Inconsistent with hypothesis 1 , the results in Panel C indicate that earnings predictability (captured by "R_Pred") is negatively associated with judicial system $(\mathrm{p}<.01)$, rule of law $(\mathrm{p}<.01)$, corruption $(\mathrm{p}<.01)$, external capitalization $(\mathrm{p}<.05)$, the number of domestic firms $(\mathrm{p}<.05)$, and the number of IPOs $(\mathrm{p}<.10)$. The control variable is significant with the opposite sign of the prediction.

Table 7, Panel D reports multiple regressions between earnings smoothness rank scores and institutional variables. Consistent with hypothesis 1, the results in Panel D indicate that earnings smoothness (captured by "R_Smooth") is positively associated with judicial system $(\mathrm{p}<.01)$, rule of law $(\mathrm{p}<.01)$, corruption $(\mathrm{p}<.01)$, external capitalization $(\mathrm{p}<.01)$, and the number of domestic firms $(\mathrm{p}<.05)$, and negatively associated with ownership concentration $(\mathrm{p}<.01)$. The control variable is significant with the expected sign. 
In sum, the results based on multiple regressions are consistent with those based on cluster and correlation analyses. This means that the results based on the association between institutional characteristics and earnings attributes are mixed. Conclusions about earnings quality depend on how it is defined. If earnings quality is defined using earnings smoothness, the results are consistent with the study's hypothesis 1 implying that countries whose institutional characteristics are strong (i.e., countries in Cluster 1) appear to have less earnings smoothness. However, if earnings quality is defined using

accruals quality or earnings predictability, the results contradict the hypothesis indicating that countries whose institutional characteristics are weak (i.e., countries in Clusters 2 and 3) appear to have high accruals quality and high predictive ability of earnings. Finally, if earnings quality is based on earnings persistence, the results show that countries with low ownership concentration appear to have high earnings persistence and no other institutional variables in this study affect differences in earnings persistence across countries.

\subsection{Sensitivity Tests}

This section includes sensitivity tests of the associations and correlations between earnings attributes and institutional characteristics. Section 7.5.1 reports the sensitivity test of regression analysis between earnings attributes and institutional characteristics when the study uses the rank data rather than the raw data of institutional variables. Section 7.5.2 reports the sensitivity test of correlation matrix when all accounting variables in this study are scaled using average total assets rather than lagged total assets. Section 7.5.3 reports the sensitivity test of correlation matrix when the study excludes 
change in taxes payable from the calculation of the total accruals (TA), total current accruals (TCA), and cash flows from operations (CFO).

7.5.1 Sensitivity Test: Earnings Attributes and Institutional Characteristics (Rank Data)

To strengthen the findings in Table 7, this study considers rank data for institutional characteristics and uses the following models to test the association between earnings attributes and institutional characteristics.

- Model 1: Earnings attribute $=\mathrm{f}\left(\mathrm{R} \_\right.$InvRights $)+$control variable

- $\quad$ Model 2: Earnings attribute $=\mathrm{f}\left(\mathrm{R} \_J u d i c S y s\right)+$ control variable

- Model 3: Earnings attribute $=f\left(R \_\right.$Ruleoflaw $)+$control variable

- $\quad$ Model 4: Earnings attribute $=\mathrm{f}\left(\mathrm{R} \_\right.$Corruption $)+$control variable

- $\quad$ Model 5: Earnings attribute $=\mathrm{f}\left(\mathrm{R} \_\right.$ExtCap $)+$control variable

- Model 6: Earnings attribute $=\mathrm{f}\left(\mathrm{R} \_\right.$DoFirms $)+$control variable

- Model 7: Earnings attribute $=\mathrm{f}\left(\mathrm{R} \_I P O s\right)+$ control variable

- Model 8: Earnings attribute $=\mathrm{f}\left(\mathrm{R} \_\right.$Ownership $)+$control variable Where:

$$
\begin{aligned}
& \text { R_InvRights }=\text { Rank score of "InvRights" in an ascending order, with high } \\
& \text { R_JudicSys = Rank score of "JudicSys" in an ascending order, with high } \\
& \text { R_RuleofLaw = Rank score of "RuleofLaw" in an ascending order, with high } \\
& \text { R_Corruption = Rank score of "Corruption" in an ascending order, with high }
\end{aligned}
$$




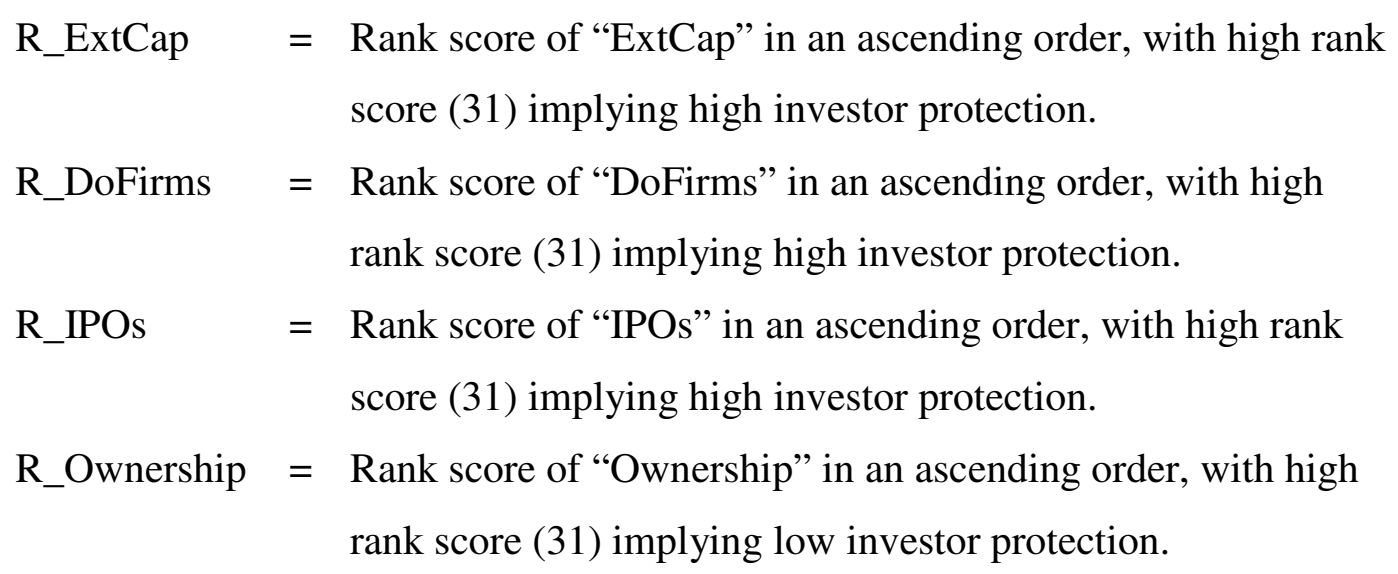

Table 8, Panel A presents stronger results as compared to those in Table 7, Panel A. The results of the association between accruals quality and institutional characteristics (using rank data) still report all four significant institutional variables in Table 7, Panel A. In addition, two more institutional variables ("R_ExtCap" and "R_IPOs") turn from insignificant to significant at $\mathrm{p}<.05$ and $\mathrm{P}<.01$, respectively. However, the ownership concentration is still not significant. Again, these results are not consistent with hypothesis 1 and the control variable is still significant with the opposite sign of the prediction.

Table 8, Panel B presents similar results as compared to those in Table 7, Panel B. Again, these results of the association between earnings persistence and institutional characteristics (using rank data) are not consistent with hypothesis 1 and the control variable is still insignificant for all models. Only ownership concentration variable is significant $(\mathrm{p}<.01)$ with the predicted sign.

Table 8, Panel C presents stronger results as compared to those of Table 7, Panel C. The results of the association between earnings predictability and institutional characteristics (using rank data) still report all six significant institutional variables in 
Table 7, Panel C. In addition, one more institutional variable ("R_Ownership") turns from insignificant to significant at $\mathrm{p}<.10$ with the opposite sign. Again, these results are not consistent with hypothesis 1 and the control variable is still significant with the opposite sign of the prediction.

Table 8, Panel D presents stronger results as compared to those in Table 7, Panel D. The results of the association between earnings smoothness and institutional characteristics (using rank data) still report all six significant institutional variables in Table 7, Panel D. In addition, two institutional variables ("R_InvRights" and "R_IPOs") turn from insignificant to significant at $\mathrm{p}<.10$. The ownership concentration is still negative and significant at $\mathrm{p}<.01$. Again, only the results based on earnings smoothness are consistent with hypothesis 1 and the sign prediction.

\subsubsection{Sensitivity Test: Scaling Accounting Variables Using Average Total Assets}

There are differences in prior research in measuring accruals using different types of scaling. Some studies (e.g., Dechow et al. 1995; Hribar and Collins 2002; Leuz et al. 2003; Bhattacharya et al. 2003; Kothari et al. 2005; Wysocki 2005) scale all accounting variables by lagged total assets while other studies (e.g., Sloan 1996; Dechow and Dichev 2002; Desai et al. 2004; Francis et al. 2004) scale all variables by average total assets. Cheng and Thomas (2005) examine these different types of scaling and find that choices related to accrual measurement significantly impact the amount of evidence regarding the abnormal accrual anomaly in their study. To determine whether the results of this study vary with different type of scaling, this study measures all accounting variables using average total assets rather than lagged total assets. Table 9, Panel A reports Spearman- 
rank correlation coefficients between earnings attributes. Consistent with the results in Table 3, Panel C, the results (right-hand side) based on Spearman-rank correlations indicate that earnings smoothness (captured by "Smooth") has a negative correlation with accruals quality (captured by "Stdresid") and earnings predictability (captured by "Pred"), which is inconsistent with the study's expectation. Table 9, Panel B reports Spearman-rank correlation coefficients between institutional characteristics and earnings attributes (rank score). The results are consistent with those in Table 6, Panel B.

\subsubsection{Sensitivity Test: Not Including Change in Taxes Payable in Total Accrual Calculation}

There are differences in prior research in estimating an accrual component of earnings. Some studies (e.g., Sloan 1996; Dechow and Dichev 2002; Leuz et al. 2003; Bhattacharya et al. 2003; Desai et al. 2004; Wysocki 2005) include change in taxes payable as part of the estimation of the accrual component of earnings while other studies (e.g., Dechow et al. 1995; Hribar and Collins 2002; Francis et al. 2004; Kothari et al. 2005) exclude change in taxes payable when calculating this accrual component. To determine whether the results of this study vary if change in taxes payable is excluded in the calculation of total accruals (TA), total current accruals (TCA), and cash flows from operation (CFO). Table 10, Panel A reports Spearman-rank correlation coefficients between earnings attributes. Consistent with the results in Table 3, Panel C, the results (right-hand side) based on Spearman-rank correlations indicate that earnings smoothness (captured by "Smooth") has a negative correlation with accruals quality (captured by 
"Stdresid") and earnings predictability (captured by "Pred"), which is inconsistent with the study's expectation.

Table 10, Panel B reports Spearman-rank correlation coefficients between institutional characteristics and earnings attributes (rank score). The results are consistent with those in Table 6, Panel B.

\subsection{Summary}

Overall, the K-means cluster, correlation, and regression analyses in previous sections all indicate mixed results across the four earnings attributes. Consistent with Leuz et al. (2003), the findings based on earnings smoothness support the first hypothesis that firms with the least favorable values of each earnings attribute (captured by earnings smoothness) generally occur in countries whose institutional characteristics provide weaker protection of investors than in countries with stronger investor protection. Conversely, this study finds opposite results when measuring earnings attributes based on accruals quality and earnings predictability and no association between differences in institutional characteristics and those of earnings persistence across countries. This conclusion holds under the assumption that the four earnings attributes measures correctly proxy earnings quality. It may be that the four earnings attributes measures used in this study are not (or are less) suitable in international settings. These measures have been used extensively in prior research, but most prior studies are based on a singlecountry setting, particularly the United States. 


\section{CHAPTER 8}

\section{SUMMARY AND CONCLUSIONS \\ LIMITATIONS AND FUTURE RESEARCH}

\subsection{Summary and Conclusions}

This study attempts to explore the relationship between cross-country differences in the quality of reported earnings (proxied by four accounting-based earnings attributes) and investor protection (proxied by eight national institutional characteristics), hypothesizing that the least favorable values of each earnings attribute (considered individually) generally occur in countries whose institutional characteristics provide weaker investor protection than in countries with stronger investor protection. This study uses K-means cluster, correlation, and regression analyses to test the hypothesis.

The results based on K-means cluster and correlation analyses between institutional characteristics and earnings attributes are mixed. This means that if the study defines earnings quality based on earnings smoothness, the results are consistent with the study's hypothesis implying that less earnings smoothness appears to be found in countries whose institutional characteristics are strong (i.e., countries in Cluster 1). If the study defines earnings quality based on accruals quality and earnings predictability, the results contradict the study's hypothesis, indicating that high accruals quality and high predictive ability of earnings appear to be found in countries whose institutional 
characteristics are weak (i.e., countries in Clusters 2 and 3). In addition, if the study defines earnings quality based on earnings persistence, the results show no effect of differential institutional characteristics on earnings persistence, except that countries with low ownership concentration appear to have high earnings persistence. The regression results are consistent with those based on cluster and correlation analyses. Thus, the results based on the association between institutional characteristics and earnings attributes are mixed.

There are several possible reasons for the mixed results. First, it is possible that certain of the earnings attributes measures used in this study are not the right surrogates to capture earnings quality. In other words, some of these measures may not be wellspecified when applied to international data. For example, using a sample of U.S. and international firms, Wysocki (2005) documents that the widely-used Dechow and Dichev (DD, 2002) accruals quality model fails to capture, and even reverse ranks, firms' earnings quality as this model is dominated by the negative contemporaneous correlation between accruals and cash flows. The Wysocki (2005) result may explain the inconsistent results found in this study for accruals quality and earnings smoothness. The results for earnings smoothness and predictability are also inconsistent in this study. Perhaps these two measures capture earnings quality oppositely in an international setting. An argument can be made that smoother earnings are more predictable, and viceversa. Countries (e.g., Japan or Greece) whose earnings are more smoothed may have more predictable earnings than countries (e.g., USA or UK) whose earnings are less smoothed. 
The mixed results may also be due to the fact that the samples are not homogeneous across the countries represented. They vary in terms of size and industry membership. For example, it is likely that most countries in cluster 3 contain more small firms and firms engaged in "commodities" type of industry while most countries in cluster 1 contain large firms and firms with "hi-tech manufacturing" specialization. The incentives and opportunities for corporate insiders to manipulate a company's earnings probably vary across industries and size of company.

Finally, it may be that investor protection variables do not reflect a country's "true" impact on earnings quality. There might be other factors such as the nature of a country's capital market itself driving the results of this study. For example, in developing countries whose capital markets are less significant, there are fewer incentives for corporate insiders to manipulate earnings because not many investors are using financial information in decision making. Managers in these countries have nothing to gain from manipulating earnings. As a result, accruals quality or earnings predictability in developing countries may be higher than that in developed countries where capital markets are more significant and managers have more to gain from manipulating earnings.

The findings of this study provides some, though limited, insights into crosscountry differences in earnings attributes and linkage between these earnings attributes (as measures of earnings quality) and the protection of investors' rights. One implication is that conclusions about earnings quality depend on the definition of earnings quality. Another possible implication is that other national institutional characteristics besides investor protection may significantly influence measures of earnings quality. Thus, 
investors and other financial information users should exercise caution when considering the effect of investor protection on earnings quality across countries. Furthermore, investors exposed to other equity markets (e.g., developed versus emerging equity markets) need to be aware of the effect of other institutional characteristic differences on earnings attributes when they invest time and effort in better understanding these differences across countries.

\subsection{Limitations and Future Research}

This study has some important limitations that need to be considered when interpreting the results. First, it is possible that earnings attributes and investor protection variables are all impacted by unknown variables. This could result in a spurious association between earnings attributes and investor protection. Even though this study attempts to control for the factors suggested by prior studies, there are still some other factors (e.g. culture and other aspects of corporate governance) that have not been controlled. Second, this study employs four earnings attribute measures suggested from prior studies. Most of these prior studies are based on the United States. Perhaps these earnings attributes are less applicable in a cross-country setting or are measured with error. Third, some values of the investor protection variables (such as antidirector rights and ownership concentration) are the same across the period of this study. This does not reflect the reality of a country's development in its investor protection level as it is probably not constant over time. Finally, classifying firms on the basis of their country of incorporation in Global Vantage Database implies that home-country institutions are expected to have the strongest influence on observed earnings attributes. However, this 
assumption may introduce a bias into the study since firms engaged in cross-border product or financial transactions could also be influenced by the institutions of those additional countries. To that extent, cross-border transactions are expected to diminish the power of this study's tests.

Because of the scarce amount of empirical research examining the impact of investor protection on more than one earnings attribute, several possible avenues for future research exist. One avenue for future research is the impact of investor protection on market-based earnings attributes (i.e., value relevance, conservatism, timeliness, etc.). Another avenue for future research is investigating the mixed results in this study. As noted earlier, Wysocki (2005) challenges the Dechow and Dichev (2002) accruals quality model used in this and many other studies. Replicating the results using an alternative specification of accruals quality, such as the one proposed by Wysocki (2005), is a second avenue for future research.

Further, this study raises the possibilities that measures of persistence and predictive ability of earnings used in prior literature are not well specified in an international context. For example, the theory could be wrong for some earnings attributes such as earnings persistence and earnings predictability. The theories supporting the relationship between investor protection and earnings management are supported by the belief that the use of earnings management by insiders to conceal firm performance from outsiders can be reduced with strong investor protection. In other words, when a country has a strong investor protection, this protection limits insiders' ability to acquire private control benefits, which reduces their incentives to mask firm performance. However, there is a lack of theories supporting the relationship between 
investor protection and other aspects of earnings attributes such as earnings persistence and earnings predictability. Thus, theoretical work on these measures is a third avenue for future research. 


\section{REFERENCES}

Alford, A., J. Jones, R. Leftwich, and M. Zmijewski. 1993. The Relative Informativeness of Accounting Disclosures in Different Countries. Journal of Accounting Research 31 (Studies on International Accounting), 183-223.

Ali, A., and L.-S. Hwang. 2000. Country-Specific Factors Related to Financial Reporting and the Value Relevance of Accounting Data. Journal of Accounting Research 38 (1), 1-21.

Ashbaugh, H., and R. LaFond. 2003. Reporting Incentives and the Quality of Non-U.S. Firms' Working Capital Accruals. Working paper, University of Wisconsin.

Ball, R., S.P. Kothari, and A. Robin. 2000. The Effect of International Institutional Factors on Properties of Accounting Earnings. Journal of Accounting and Economics 29 (1), 1-51.

Ball, R., A. Robin, and J.S. Wu. 2003. Incentives Versus Standards: Properties of Accounting Income in Four East Asian Countries. Journal of Accounting and Economics 36 (1-3), 235-270.

Ball, R., and L. Shivakumar. 2004. Earnings Quality in U.K. Private Firms. Working Paper, University of Chicago and London Business School.

Balsam, S., J. Krishnan, and J.S. Yang. 2003. Auditor Industry Specialization and Earnings Quality. Auditing 22 (2), 71-97.

Barth, M.E., W.H. Beaver, J.R. Hand, and W.R. Landsman. 1999. Accruals, Cash Flows, and Equity Values. Review of Accounting Studies 4 (3-4), 205-229.

Beck, T., R. Levine, and N. Loayza. 2000. Finance and the Sources of Growth. Journal of Financial Economics 58 (1-2), 261-300.

Beneish, M.D., and M.E. Vargus. 2002. Insider Trading, Earnings Quality, and Accrual Mispricing. The Accounting Review 77 (4), 755.

Bhattacharya, U., H. Daouk, and M. Welker. 2003. The World Price of Earnings Opacity. The Accounting Review 78 (3), 641-678. 
Bowen, R., S. Rajgopal, and M. Venkatachalam. 2003. Accounting Discretion, Corporate Governance and Firm Performance. Working Paper, University of Washington and Duke University.

Bricker, R., G. Previts, T. Robinson, and S. Young. 1995. Financial Analyst Assessment of Company Earnings Quality. Journal of Accounting, Auditing \& Finance 10 (3), 541-553.

Burgstahler, D., L. Hail, and C. Leuz. 2004. The Importance of Reporting Incentives: Earnings Management in European Private and Public Firms. Working Paper, University of Washington, University of Zurich, and University of Pennsylvania.

Bushman, R.M., and J.D. Piotroski. 2005. Financial Reporting Incentives for Conservative Accounting: The Influence of Legal and Political Institutions. Journal of Accounting and Economics (Forthcoming).

Bushman, R.M., and A.J. Smith. 2001. Financial Accounting Information and Corporate Governance. Journal of Accounting and Economics 32 (1-3), 237-333.

Cheng, C., and W. Thomas. 2005. Evidence of the Abnormal Accrual Anomaly Incremental to Operating Cash Flows. Working paper, University of Houston and University of Oklahoma.

Dechow, P.M., and I.D. Dichev. 2002. The Quality of Accruals and Earnings: The Role of Accrual Estimation Errors. The Accounting Review 77 (Supplement), 35-59.

Dechow, P.M., R.G. Sloan, and A.P. Sweeney. 1995. Detecting Earnings Management. The Accounting Review 70 (2), 193-225.

DeFond, M., M. Hung, and R. Trezevant. 2004. Investor Protection and the Information Content of Annual Earnings Announcement: International Evidence. Working paper, University of Southern California.

Deloitte \& Touche. 2004. Quality of Earnings. Integrity \& Quality: Quality of Earnings.

Desai, H., S. Raigopal, and M. Venkatachalam. 2004. Value-Glamour and Accrual Mispricing: One Anomaly or Two? The Accounting Review 79 (April), 355-385.

Financial Accounting Standard Board (FASB). 1980. Qualitative Characteristics of Accounting Information. Statement of Financial Accounting Concept No. 2 Stamford, CT.

Francis, J., R. LaFond, P. Olsson, and K. Schipper. 2003. Earnings Quality and the Pricing Effects of Earnings Patterns. Working paper, Duke University, University of Wisconsin and the FASB. 
Francis, J., R. LaFond, P.M. Olsson, and K. Schipper. 2004. Costs of Equity and Earnings Attributes. The Accounting Review 79 (4), 967-1010.

Fulkerson, C., S. Jackson, and G. Meek. 2004. The Consequences of International Accounting Diversity on Earnings Management and Earnings Quality. Working Paper, University of Texas at San Antonio and Oklahoma State University.

Guenther, D., and D. Young. 2000. The Association Between Financial Accounting Measures and Real Economic Activity: A Multinational Study. Journal of Accounting and Economics (1), 53-72.

Hanlon, M., S. Rajgopal, and T. Shevlin. 2003. Are Executive Stock Options Associated With Future Earnings? Journal of Accounting and Economics 36 (1-3), 3-43.

Harris, T., E. Huh, and P. Fairfield. 2000. Gauging Profitability of the Road to Valuation. Strategy Report, Global Valuation and Accounting, Morgan Stanley Dean Witter.

Hartland-Peel, C. 1996. African Equities: A Guide to Markets and Companies. Euromoney Publications London, UK.

Haw, I.-M., B. Hu, L.-S. Hwang, and W. Wu. 2004. Ultimate Ownership, Income Management, and Legal and Extra-Legal Institutions. Journal of Accounting Research 42 (2), 423-462.

Hicks, J. 1939. Value and Capital (Oxford University Press, Oxford, U.K.).

Hribar, P., and D. Collins. 2002. Errors in Estimating Accruals: Implications for Empirical Research. Journal of Accounting Research 40 (1), 105-134.

Hung, M. 2001. Accounting Standards and Value Relevance of Financial Statements: An International Analysis. Journal of Accounting and Economics 30 (3), 401-420.

Hunt, A., S. Moyer, and T. Shevlin. 1997. Earnings Volatility, Earnings Management, and Equity Value. Working Paper, University of Washington.

International Finance Corporation. 2001. Emerging Markets Data Base, located online at: http://www.ifc.org/EMDB/EMDBHOME.HTM.

Jones, J.J. 1991. Earnings Management During Import Relief Investigations. Journal of Accounting Research 29 (2), 193-228.

Kaufmann, D., A. Kraay, and M. Mastruzzi. 2004. Governance Matters III: Governance Indicators for 1996, 1998, 2000, and 2002. World Bank Econ Rev 18 (2), 253-287.

Kormendi, R., and R. Lipe. 1987. Earnings Innovations, Earnings Persistence, and Stock Returns. Journal of Business 60 (3), 323-345. 
Kothari, S. P., A. Leone, and C. Wasley. 2005. Performance Matched Discretionary Accrual Measures. Journal of Accounting and Economics 39 (1), 163-197.

La Porta, R., F. Lopez-de-Silanes, and A. Shleifer. 1999. Corporate Ownership around the World. Journal of Finance 54 (2), 471-517.

La Porta, R., F. Lopez-De-Silanes, and A. Shleifer. 2004. What Works in Securities Laws? Working paper, Dartmouth College, Yale University, and Harvard University.

La Porta, R., F. Lopez-De-Silanes, A. Shleifer, and R. Vishny. 1997. Legal Determinants of External Finance. The Journal of Finance 52 (3), 1131-1150.

. 1998. Law and Finance. Journal of Political Economy 106 (6), 1113-1150.

La Porta, R., F. Lopez-de-Silanes, A. Shleifer, and R. Vishny. 2000. Investor Protection and Corporate Governance. Journal of Financial Economics 58 (1), 3-27.

Lang, M., J.S. Raedy, and M.H. Yetman. 2003. How Representative Are Firms That Are Cross-Listed in the United States? An Analysis of Accounting Quality. Journal of Accounting Research 41 (2), 363-386.

Leuz, C., D. Nanda, and P.D. Wysocki. 2003. Earnings Management and Investor Protection: An International Comparison. Journal of Financial Economics 69 (3), 505-527.

Lev, B. 1989. On the Usefulness of Earnings and Earnings Research: Lessons and Directions from Two Decades of Empirical Research. Journal of Accounting Research 27 (3), 153.

Lipe, R. 1990. The Relation between Stock Returns and Accounting Earnings Given Alternative Information. Accounting Review 65 (1), 49-71.

MacQueen, J.B. 1967. Some Methods for Classification and Analysis of Multivariate Observations. Proceedings of 5-th Berkeley Symposium on Mathematical Statistics and Probability (1), 281-297.

McNichols, M.F., 2002, Discussion of The Quality of Accruals and Earnings: The Role of Accrual Estimation Errors., Accounting Review (American Accounting Association).

Meek, G.K., and W.B. Thomas. 2004. A Review of Markets-Based International Accounting Research. Journal of International Accounting Research 3 (1), 21-41. 
Mikhail, M.B., B.R. Walther, and R.H. Willis, 2003, Reactions to Dividend Changes Conditional on Earnings Quality., Journal of Accounting, Auditing \& Finance (Greenwood Publishing Group Inc.).

Myers, J.N., L.A. Myers, and T.C. Omer. 2003. Exploring the Term of the Auditor-Client Relationship and the Quality of Earnings: A Case for Mandatory Auditor Rotation? The Accounting Review 78 (3), 779-799.

Penman, S. 2001. Financial Statement Analysis and Security Valuation. New York, NY: McGraw-Hill/Irwin.

Penman, S.H., and X.-J. Zhang, 2002, Accounting Conservatism, the Quality of Earnings, and Stock Returns., Accounting Review (American Accounting Association).

Pincus, M., and S. Rajgopal. 2002. The Interaction between Accrual Management and Hedging: Evidence from Oil and Gas Firms. The Accounting Review 77 (1), 127 160.

Richardson, S. 2003. Earnings Quality and Short Sellers. Accounting Horizons 17 (Supplement), 49-61.

Ricol, R. 2004. The Role of Accountancy in Economic Development. IFAC Speech presented to the United Nations Conference on Trade and Development on June 16, 2004.

Schipper, K., and L. Vincent. 2003. Earnings Quality. Accounting Horizons 17 (Supplement), 97-110.

Shleifer, A., and R.W. Vishny. 1997. A Survey of Corporate Governance. Journal of Finance 52 (2), 737-783.

Shleifer, A., and D. Wolfenzon. 2002. Investor Protection and Equity Markets. Journal of Financial Economics 66 (1), 3-27.

Sloan, R. 1996. Do Stock Prices Fully Reflect Information in Accruals and Cash Flows About Future Earnings? The Accounting Review 71 (3), 289-315.

Teets, W.R. 2002. Quality of Earnings: An Introduction to the Issues in Accounting Education Special Issue. Issues in Accounting Education 17 (4), 355.

Wong, P., 2004, Challenges and Successes in Implementing International Standards: Achieving Covergence to IFRs and ISAs, IFAC Newsletter (September 2004).

World Bank. 2001. World Development Indicators 2001, [CD-ROM] (World Bank, Washington, DC). 
Wysocki, P.D. 2004. Discussion of Ultimate Ownership, Income Management, and Legal and Extra-Legal Institutions. Journal of Accounting Research 42 (2), 463-474.

Wysocki, P.D. 2005. Assessing Earnings and Accruals Quality: U.S. and International Evidence. Working Paper, MIT Sloan School of Management. 
APPENDIXES 


\section{APPENDIX 1 \\ Earnings Quality Definitions and Measures}

This appendix describes how prior research studies define and measure the quality of earnings.

\begin{tabular}{|c|l|l|}
\hline \multicolumn{1}{|c|}{ Definitions of Earnings Quality } & \multicolumn{1}{|c|}{ Measures } & \multicolumn{1}{c|}{ Article (s) } \\
\hline $\begin{array}{c}\text { Firms with high accruals quality will } \\
\text { have high earnings persistence, which refers } \\
\text { to high earnings quality. }\end{array}$ & $\begin{array}{l}\text { - Accruals quality } \\
\text { - Earnings persistence } \\
\text { Dichow and }\end{array}$ \\
\hline $\begin{array}{c}\text { Earnings is of good quality if it has high } \\
\text { accruals quality and high earnings response } \\
\text { coefficient. }\end{array}$ & $\begin{array}{l}\text { - Accruals quality } \\
\text { - Earnings response } \\
\text { coefficient (ERC) }\end{array}$ & $\begin{array}{l}\text { Balsam et al. } \\
(2003)\end{array}$ \\
\hline $\begin{array}{c}\text { Earnings is of good quality if it has high } \\
\text { accruals quality or less absolute abnormal } \\
\text { accruals }\end{array}$ & $\begin{array}{l}\text { - Accruals quality } \\
\text { - Modified Jones [1991] }\end{array}$ & $\begin{array}{l}\text { Francis et al. } \\
(2003)\end{array}$ \\
\hline $\begin{array}{c}\text { Earnings is of good quality if it has high } \\
\text { accruals quality, which refers to the effects } \\
\text { of changes in accounting estimates (i.e., } \\
\text { accruals) }\end{array}$ & - Accruals quality & $\begin{array}{l}\text { Myers et al. } \\
(2003)\end{array}$ \\
\hline $\begin{array}{c}\text { Earnings quality is defined as the } \\
\text { likelihood that a firm can sustain current } \\
\text { earnings in the future. }\end{array}$ & - Earnings persistence & $\begin{array}{l}\text { Beneish and } \\
\text { Vargus (2002) }\end{array}$ \\
\hline $\begin{array}{c}\text { Earnings is of good quality if it is a good } \\
\text { indicator of future earnings, which refers to } \\
\text { "substantial earnings". }\end{array}$ & - Earnings persistence & $\begin{array}{l}\text { Penman and } \\
\text { Zhang (2002) }\end{array}$ \\
\hline $\begin{array}{l}\text { Earnings is of good quality if it is high } \\
\text { persistent. }\end{array}$ & - Earnings persistence & $\begin{array}{l}\text { Richardson } \\
(2003)\end{array}$ \\
\hline
\end{tabular}


APPENDIX 1 (Concluded)

Earnings Quality Definitions and Measures

\begin{tabular}{|c|c|c|}
\hline Definitions of Earnings Quality & Measures & Article (s) \\
\hline $\begin{array}{l}\text { Earnings is of good quality if it has a } \\
\text { low level of earnings volatility, which } \\
\text { refers to high predictive ability of } \\
\text { earnings. }\end{array}$ & - Earnings predictability & $\begin{array}{l}\text { Bricker et al. } \\
(1995)\end{array}$ \\
\hline $\begin{array}{l}\text { Earnings quality is defined as the extent } \\
\text { to which a firm's past earnings is } \\
\text { associated with its future cash flows. }\end{array}$ & - Earnings predictability & $\begin{array}{l}\text { Mikhail et al. } \\
(2003)\end{array}$ \\
\hline $\begin{array}{l}\text { Earnings is viewed to be of high quality } \\
\text { if it is characterized by less evidence of } \\
\text { earnings management, more timely } \\
\text { recognition of bad news, and a higher } \\
\text { association with share price. }\end{array}$ & $\begin{array}{l}\text { - Earnings management } \\
\text { measures (i.e., earnings } \\
\text { smoothness, Jones } \\
\text { [1991] model, frequency } \\
\text { of small positive earnings) } \\
\text { - Timely loss recognition } \\
\text { - The relation of stock } \\
\text { prices with accounting } \\
\text { data }\end{array}$ & $\begin{array}{l}\text { Lang et al. } \\
(2003)\end{array}$ \\
\hline $\begin{array}{l}\text { High earnings quality is in the sense } \\
\text { that earnings is less likely to distort firms' } \\
\text { underlying economic performance. }\end{array}$ & $\begin{array}{l}\text { - Earnings management } \\
\text { measures based on Leuz et } \\
\text { al. (2003) }\end{array}$ & $\begin{array}{l}\text { Defond et al. } \\
(2004)\end{array}$ \\
\hline $\begin{array}{l}\text { Earnings is of good quality if it has } \\
\text { more timely loss recognition. }\end{array}$ & - Timely loss recognition & $\begin{array}{l}\text { Ball and } \\
\text { Shivakumar } \\
(2004)\end{array}$ \\
\hline $\begin{array}{l}\text { Quality of earnings is defined as the } \\
\text { relationship between profitability and cash } \\
\text { generating ability. }\end{array}$ & $\begin{array}{l}\text { - Value relevance of cash } \\
\text { flow disclosures }\end{array}$ & $\begin{array}{l}\text { Bricker et al. } \\
(1995)\end{array}$ \\
\hline
\end{tabular}




\section{APPENDIX 2}

Data Source

\begin{tabular}{|c|c|c|}
\hline Variable & Variable Name & Data Source \\
\hline TotalAsset & Total assets & $\begin{array}{l}\text { Global Vantage Industry Research and } \\
\text { Industry Active Files. }\end{array}$ \\
\hline REV & Total revenue & $\begin{array}{l}\text { Global Vantage Industry Research and } \\
\text { Industry Active Files. }\end{array}$ \\
\hline PPE & Property, plant, and equipment & $\begin{array}{l}\text { Global Vantage Industry Research and } \\
\text { Industry Active Files. }\end{array}$ \\
\hline $\mathrm{CA}$ & Total current assets & $\begin{array}{l}\text { Global Vantage Industry Research and } \\
\text { Industry Active Files. }\end{array}$ \\
\hline CL & Total current liabilities & $\begin{array}{l}\text { Global Vantage Industry Research and } \\
\text { Industry Active Files. }\end{array}$ \\
\hline $\mathrm{CASH}$ & Cash & $\begin{array}{l}\text { Global Vantage Industry Research and } \\
\text { Industry Active Files. }\end{array}$ \\
\hline STDEBT & Debt in current liabilities & $\begin{array}{l}\text { Global Vantage Industry Research and } \\
\text { Industry Active Files. }\end{array}$ \\
\hline Dep & Depreciation and amortization & $\begin{array}{l}\text { Global Vantage Industry Research and } \\
\text { Industry Active Files. }\end{array}$ \\
\hline Earn & $\begin{array}{l}\text { Net income before } \\
\text { extraordinary items }\end{array}$ & $\begin{array}{l}\text { Global Vantage Industry Research and } \\
\text { Industry Active Files. }\end{array}$ \\
\hline TCA & Total current accruals & $\begin{array}{l}\text { Global Vantage Industry Research and } \\
\text { Industry Active Files. }\end{array}$ \\
\hline TA & Total accruals & $\begin{array}{l}\text { Global Vantage Industry Research and } \\
\text { Industry Active Files. }\end{array}$ \\
\hline $\mathrm{CFO}$ & Cash flow from operation & $\begin{array}{l}\text { Global Vantage Industry Research and } \\
\text { Industry Active Files. }\end{array}$ \\
\hline InvRights & Anti-director rights & La Porta et al. (Working paper, 2004). \\
\hline JudicSys & Efficiency of judiciary & La Porta et al. (Working paper, 2004) \\
\hline RuleofLaw & Rule of law & La Porta et al. (Working paper, 2004) \\
\hline Corruption & Corruption index & La Porta et al. (Working paper, 2004) \\
\hline Extcap & External Cap/GDP & La Porta et al. (Working paper, 2004) \\
\hline DoFirms & Domestic Firms/Pop & La Porta et al. (Working paper, 2004) \\
\hline IPOs & IPOs/GDP & La Porta et al. (Working paper, 2004) \\
\hline Ownership & Ownership Concentration & La Porta et al. (Working paper, 2004) \\
\hline Pub_enf & Public Enforcement & La Porta et al. (Working paper, 2004) \\
\hline
\end{tabular}




\section{APPENDIX 3}

TABLE 1

Sample: Firm-Year Observations

Panel A: Firm-year observations based on legal origin

\begin{tabular}{|c|c|c|c|c|c|c|c|c|c|c|}
\hline Country & Legal Origin & 1996 & 1997 & 1998 & 1999 & 2000 & 2001 & 2002 & $\mathrm{~N}$ & $\%$ \\
\hline Australia & English & 110 & 121 & 165 & 197 & 219 & 236 & 242 & 1,290 & \\
\hline Canada & English & 221 & 232 & 240 & 279 & 291 & 297 & 287 & 1,847 & \\
\hline Hong Kong & English & 43 & 46 & 81 & 86 & 90 & 98 & 99 & 543 & \\
\hline India & English & 75 & 77 & 107 & 192 & 191 & 192 & 185 & 1,019 & \\
\hline Malaysia & English & 135 & 188 & 345 & 383 & 395 & 425 & 431 & 2,302 & \\
\hline Singapore & English & 95 & 98 & 145 & 183 & 227 & 269 & 285 & 1,302 & \\
\hline South Africa & English & 21 & 21 & 43 & 46 & 49 & 48 & 50 & 278 & \\
\hline Thailand & English & 104 & 142 & 212 & 222 & 223 & 225 & 229 & 1,357 & \\
\hline United Kingdom & English & 284 & 380 & 458 & 483 & 522 & 546 & 557 & 3,230 & \\
\hline \multirow[t]{2}{*}{ USA } & English & 1,530 & 1,621 & 1,685 & 1,859 & 1,895 & 1,901 & 1,889 & 12,380 & \\
\hline & & 2,618 & 2,926 & 3,481 & 3,930 & 4,102 & 4,237 & 4,254 & 25,548 & $44.3 \%$ \\
\hline Belgium & French & 32 & 45 & 52 & 58 & 77 & 80 & 80 & 424 & \\
\hline Brazil & French & 39 & 40 & 97 & 104 & 105 & 105 & 105 & 595 & \\
\hline Chile & French & 17 & 19 & 78 & 79 & 80 & 80 & 80 & 433 & \\
\hline France & French & 159 & 224 & 288 & 345 & 410 & 437 & 436 & 2,299 & \\
\hline Greece & French & 9 & 26 & 45 & 56 & 60 & 61 & 59 & 316 & \\
\hline Indonesia & French & 59 & 88 & 136 & 153 & 161 & 171 & 184 & 952 & \\
\hline Italy & French & 41 & 80 & 90 & 99 & 142 & 159 & 160 & 771 & \\
\hline Mexico & French & 29 & 34 & 53 & 53 & 58 & 60 & 60 & 347 & \\
\hline Netherlands & French & 64 & 95 & 99 & 106 & 124 & 129 & 129 & 746 & \\
\hline Philippines & French & 17 & 29 & 90 & 93 & 90 & 92 & 94 & 505 & \\
\hline \multirow[t]{2}{*}{ Spain } & French & 46 & 70 & 73 & 84 & 91 & 93 & 94 & 551 & \\
\hline & & 512 & 750 & 1,101 & 1,230 & 1,398 & 1,467 & 1,481 & 7,939 & $13.8 \%$ \\
\hline
\end{tabular}


TABLE 1 (Continued)

Sample: Firm-Year Observations

Panel A: Firm-year observations based on legal origin (Continued)

\begin{tabular}{|c|c|c|c|c|c|c|c|c|c|c|}
\hline Country & Legal Origin & 1996 & 1997 & 1998 & 1999 & 2000 & 2001 & 2002 & $\mathrm{~N}$ & $\%$ \\
\hline Austria & German & 23 & 34 & 38 & 41 & 46 & 50 & 49 & 281 & \\
\hline Germany & German & 146 & 213 & 271 & 361 & 472 & 491 & 467 & 2,421 & \\
\hline Japan & German & 2,109 & 2,218 & 2,295 & 2,371 & 2,442 & 2,488 & 2,538 & 16,461 & \\
\hline South Korea & German & 14 & 15 & 74 & 99 & 154 & 189 & 203 & 748 & \\
\hline Switzerland & German & 79 & 102 & 120 & 122 & 144 & 150 & 152 & 869 & \\
\hline \multirow[t]{2}{*}{ Taiwan } & German & 23 & 52 & 142 & 152 & 163 & 182 & 195 & 909 & \\
\hline & & 2,394 & 2,634 & 2,940 & 3,146 & 3,421 & 3,550 & 3,604 & 21,689 & $37.6 \%$ \\
\hline Denmark & Scandinavian & 31 & 49 & 54 & 66 & 84 & 85 & 87 & 456 & \\
\hline Finland & Scandinavian & 29 & 48 & 59 & 76 & 89 & 95 & 95 & 491 & \\
\hline Norway & Scandinavian & 33 & 46 & 68 & 81 & 98 & 100 & 101 & 527 & \\
\hline \multirow[t]{2}{*}{ Sweden } & Scandinavian & 36 & 78 & 121 & 154 & 186 & 188 & 197 & 960 & \\
\hline & & 129 & 221 & 302 & 377 & 457 & 468 & 480 & 2,434 & $4.2 \%$ \\
\hline
\end{tabular}


TABLE 1 (Concluded)

Sample: Firm-Year Observations

Panel B: Firm-year observations (all countries)

\begin{tabular}{|c|c|c|c|c|c|c|c|c|c|c|}
\hline Country & Legal Origin & 1996 & 1997 & 1998 & 1999 & 2000 & 2001 & 2002 & $\mathrm{~N}$ & $\%$ \\
\hline Australia & English & 110 & 121 & 165 & 197 & 219 & 236 & 242 & 1,290 & $2.2 \%$ \\
\hline Austria & German & 23 & 34 & 38 & 41 & 46 & 50 & 49 & 281 & $0.5 \%$ \\
\hline Belgium & French & 32 & 45 & 52 & 58 & 77 & 80 & 80 & 424 & $0.7 \%$ \\
\hline Brazil & French & 39 & 40 & 97 & 104 & 105 & 105 & 105 & 595 & $1.0 \%$ \\
\hline Canada & English & 221 & 232 & 240 & 279 & 291 & 297 & 287 & 1,847 & $3.2 \%$ \\
\hline Chile & French & 17 & 19 & 78 & 79 & 80 & 80 & 80 & 433 & $0.8 \%$ \\
\hline Denmark & Scandinavian & 31 & 49 & 54 & 66 & 84 & 85 & 87 & 456 & $0.8 \%$ \\
\hline Finland & Scandinavian & 29 & 48 & 59 & 76 & 89 & 95 & 95 & 491 & $0.9 \%$ \\
\hline France & French & 159 & 224 & 288 & 345 & 410 & 437 & 436 & 2,299 & $4.0 \%$ \\
\hline Germany & German & 146 & 213 & 271 & 361 & 472 & 491 & 467 & 2,421 & $4.2 \%$ \\
\hline Greece & French & 9 & 26 & 45 & 56 & 60 & 61 & 59 & 316 & $0.5 \%$ \\
\hline Hong Kong & English & 43 & 46 & 81 & 86 & 90 & 98 & 99 & 543 & $0.9 \%$ \\
\hline India & English & 75 & 77 & 107 & 192 & 191 & 192 & 185 & 1,019 & $1.8 \%$ \\
\hline Indonesia & French & 59 & 88 & 136 & 153 & 161 & 171 & 184 & 952 & $1.7 \%$ \\
\hline Italy & French & 41 & 80 & 90 & 99 & 142 & 159 & 160 & 771 & $1.3 \%$ \\
\hline Japan & German & 2,109 & 2,218 & 2,295 & 2,371 & 2,442 & 2,488 & 2,538 & 16,461 & $28.6 \%$ \\
\hline Malaysia & English & 135 & 188 & 345 & 383 & 395 & 425 & 431 & 2,302 & $4.0 \%$ \\
\hline Mexico & French & 29 & 34 & 53 & 53 & 58 & 60 & 60 & 347 & $0.6 \%$ \\
\hline Netherlands & French & 64 & 95 & 99 & 106 & 124 & 129 & 129 & 746 & $1.3 \%$ \\
\hline Norway & Scandinavian & 33 & 46 & 68 & 81 & 98 & 100 & 101 & 527 & $0.9 \%$ \\
\hline Philippines & French & 17 & 29 & 90 & 93 & 90 & 92 & 94 & 505 & $0.9 \%$ \\
\hline Singapore & English & 95 & 98 & 145 & 183 & 227 & 269 & 285 & 1,302 & $2.3 \%$ \\
\hline South Africa & English & 21 & 21 & 43 & 46 & 49 & 48 & 50 & 278 & $0.5 \%$ \\
\hline South Korea & German & 14 & 15 & 74 & 99 & 154 & 189 & 203 & 748 & $1.3 \%$ \\
\hline Spain & French & 46 & 70 & 73 & 84 & 91 & 93 & 94 & 551 & $1.0 \%$ \\
\hline Sweden & Scandinavian & 36 & 78 & 121 & 154 & 186 & 188 & 197 & 960 & $1.7 \%$ \\
\hline Switzerland & German & 79 & 102 & 120 & 122 & 144 & 150 & 152 & 869 & $1.5 \%$ \\
\hline Taiwan & German & 23 & 52 & 142 & 152 & 163 & 182 & 195 & 909 & $1.6 \%$ \\
\hline Thailand & English & 104 & 142 & 212 & 222 & 223 & 225 & 229 & 1,357 & $2.4 \%$ \\
\hline United Kingdom & English & 284 & 380 & 458 & 483 & 522 & 546 & 557 & 3,230 & $5.6 \%$ \\
\hline \multirow[t]{2}{*}{ USA } & English & 1,530 & 1,621 & 1,685 & 1,859 & 1,895 & 1,901 & 1,889 & 12,380 & $21.5 \%$ \\
\hline & & 5,653 & 6,531 & 7,824 & 8,683 & 9,378 & 9,722 & 9,819 & 57,610 & $100.0 \%$ \\
\hline
\end{tabular}


TABLE 2

Investor Protection Proxies by Country

Panel A: Descriptive Statistics of Institutional Characteristics

\begin{tabular}{|c|c|c|c|c|c|c|c|c|}
\hline Country & $\begin{array}{c}\text { Antidirector } \\
\text { Rights }\end{array}$ & $\begin{array}{c}\text { Efficiency of } \\
\text { Judicial System }\end{array}$ & Rule of Law & $\begin{array}{c}\text { Corruption } \\
\text { Index }\end{array}$ & $\begin{array}{c}\text { External } \\
\text { Cap/GDP }\end{array}$ & $\begin{array}{c}\text { Domestic } \\
\text { Firms/Pop }\end{array}$ & IPOs/GDP & $\begin{array}{c}\text { Ownership } \\
\text { Concentration }\end{array}$ \\
\hline Australia & 4.00 & 10.00 & 2.00 & 2.05 & 0.63 & 66.43 & 6.49 & 0.28 \\
\hline Austria & 2.00 & 9.50 & 2.10 & 1.93 & 0.07 & 12.18 & 1.71 & 0.58 \\
\hline Belgium & 0.00 & 9.50 & 1.64 & 1.36 & 0.33 & 15.62 & 2.04 & 0.54 \\
\hline Brazil & 3.00 & 5.75 & -0.15 & 0.01 & 0.13 & 2.95 & 0.04 & 0.57 \\
\hline Canada & 5.00 & 9.25 & 2.01 & 2.30 & 0.61 & 92.19 & 8.49 & 0.40 \\
\hline Chile & 5.00 & 7.25 & 1.33 & 1.54 & 0.50 & 23.00 & 0.36 & 0.45 \\
\hline Denmark & 2.00 & 10.00 & 1.97 & 2.36 & 0.31 & 43.71 & 1.29 & 0.45 \\
\hline Finland & 3.00 & 10.00 & 2.13 & 2.54 & 0.93 & 25.78 & 3.45 & 0.37 \\
\hline France & 3.00 & 8.00 & 1.49 & 1.46 & 0.49 & 13.29 & 2.56 & 0.34 \\
\hline Germany & 1.00 & 9.00 & 1.91 & 1.72 & 0.26 & 10.65 & 3.67 & 0.48 \\
\hline Greece & 2.00 & 7.00 & 0.75 & 0.80 & 0.25 & 26.67 & 12.41 & 0.67 \\
\hline Hong Kong & 5.00 & 10.00 & 1.66 & 1.44 & 1.39 & 106.13 & 8.94 & 0.54 \\
\hline India & 5.00 & 8.00 & 0.23 & -0.21 & 0.19 & 5.98 & 0.74 & 0.40 \\
\hline Indonesia & 2.00 & 2.50 & -0.90 & -1.09 & 0.12 & 1.37 & 1.58 & 0.58 \\
\hline Italy & 1.00 & 6.75 & 0.94 & 0.89 & 0.19 & 4.75 & 5.06 & 0.58 \\
\hline Japan & 4.00 & 10.00 & 1.82 & 1.38 & 0.59 & 19.55 & 2.39 & 0.18 \\
\hline Malaysia & 4.00 & 9.00 & 0.55 & 0.18 & 0.78 & 33.02 & 5.09 & 0.54 \\
\hline Mexico & 1.00 & 6.00 & -0.37 & -0.39 & 0.11 & 1.94 & 0.26 & 0.64 \\
\hline Netherlands & 2.00 & 10.00 & 1.97 & 2.34 & 0.88 & 14.00 & 2.80 & 0.39 \\
\hline Norway & 4.00 & 10.00 & 2.01 & 2.11 & 0.25 & 43.65 & 3.26 & 0.36 \\
\hline Philippines & 3.00 & 4.75 & -0.50 & -0.49 & 0.28 & 2.97 & 1.69 & 0.57 \\
\hline Singapore & 4.00 & 10.00 & 2.12 & 2.50 & 0.80 & 89.20 & 7.08 & 0.49 \\
\hline South Africa & 5.00 & 6.00 & 0.30 & 0.50 & 0.78 & 15.11 & 0.63 & 0.52 \\
\hline South Korea & 2.00 & 6.00 & 0.65 & 0.45 & 0.32 & 15.69 & 3.97 & 0.23 \\
\hline Spain & 4.00 & 6.25 & 1.38 & 1.66 & 0.32 & 18.04 & 3.11 & 0.51 \\
\hline Sweden & 3.00 & 10.00 & 1.98 & 2.48 & 0.90 & 30.40 & 12.05 & 0.28 \\
\hline Switzerland & 2.00 & 10.00 & 2.22 & 2.22 & 1.44 & 33.10 & 6.98 & 0.41 \\
\hline Taiwan & 3.00 & 6.75 & 0.87 & 0.72 & 0.83 & 21.24 & 9.60 & 0.18 \\
\hline Thailand & 2.00 & 3.25 & 0.43 & -0.34 & 0.18 & 6.69 & 0.96 & 0.47 \\
\hline United Kingdom & 5.00 & 10.00 & 1.93 & 2.17 & 1.20 & 34.97 & 11.68 & 0.19 \\
\hline USA & 5.00 & 10.00 & 1.92 & 1.77 & 1.18 & 28.93 & 5.54 & 0.20 \\
\hline
\end{tabular}


TABLE 2 (Continued)

Investor Protection Proxies by Country

Panel B: Predicted signs of country-year correlation matrix of institutional characteristics

\begin{tabular}{|l|c|c|c|c|c|c|c|c|}
\hline & \multicolumn{9}{|c|}{ Predicted Sign } \\
\cline { 2 - 10 } & InvRights & JudicSys & RuleofLaw & Corruption & ExtCap & DoFirms & IPOs & Ownership \\
\hline InvRights & & + & + & + & + & + & + \\
\hline JudicSys & + & & + & + & + & + & + \\
\hline RuleofLaw & + & + & + & + & + & + & + \\
\hline Corruption & + & + & + & + & + & + \\
\hline ExtCap & + & + & + & + & + & + & + \\
\hline DoFirms & + & + & + & + & + & + & + \\
\hline IPOs & + & + & + & + & + & + & + \\
\hline Ownership & - & - & - & - & - & - & - \\
\hline
\end{tabular}

Panel C: Correlation coefficients of country-year correlation matrix of institutional characteristics

\begin{tabular}{|c|c|c|c|c|c|c|c|c|}
\hline & \multicolumn{8}{|c|}{ Correlation Coefficient ${ }^{\text {}}$} \\
\hline & InvRights & JudicSys & RuleofLaw & Corruption & ExtCap & DoFirms & IPOs & Ownership \\
\hline InvRights & & $0.258 * * *$ & 0.106 & $0.164 * *$ & $0.452 * * *$ & $0.479 * * *$ & $0.143 * *$ & $-0.396 * * *$ \\
\hline JudicSys & $0.229 * * *$ & & $0.858 * * *$ & $0.824 * * *$ & $0.634 * * *$ & $0.731 * * *$ & $0.416 * * *$ & $-0.494 * * *$ \\
\hline RuleofLaw & $0.149 * *$ & $0.874 * * *$ & & $0.943 * * *$ & $0.507 * * *$ & $0.677 * * *$ & $0.414 * * *$ & $-0.420 * * *$ \\
\hline Corruption & $0.176 * * *$ & $0.848 * * *$ & $0.965 * * *$ & & $0.554 * * *$ & $0.671 * * *$ & $0.391 * * *$ & $-0.435 * * *$ \\
\hline ExtCap & $0.449 * * *$ & $0.556 * * *$ & $0.501 * * *$ & $0.503 * * *$ & & $0.665 * * *$ & $0.483 * * *$ & $-0.561 * * *$ \\
\hline DoFirms & $0.458 * * *$ & $0.522 * * *$ & $0.505 * * *$ & $0.513 * * *$ & $0.496 * * *$ & & $0.512 * * *$ & $-0.416 * * *$ \\
\hline IPOs & $0.126 *$ & $0.247 * * *$ & $0.251 * * *$ & $0.262 * * *$ & $0.361 * * *$ & $0.340 * * *$ & & $-0.280 * * *$ \\
\hline Ownership & $-0.378 * * *$ & $-0.405 * * *$ & $-0.457 * * *$ & $-0.406 * * *$ & $-0.470 * * *$ & $-0.139 * *$ & $-0.197 * * *$ & \\
\hline $\mathrm{N}$ & 217 & 217 & 217 & 217 & 217 & 217 & 217 & 217 \\
\hline
\end{tabular}

ж Pearson correlation matrix is presented in the upper half and Spearman-rank correlation matrix is presented in the lower half. $* * *, * * *$ denote $1 \%$ significance, $5 \%$ significance, and $10 \%$ significance, respectively (two-tailed). 
TABLE 2 (Concluded)

Investor Protection Proxies by Country

Definitions:

- Antidirector rights index indicates how easy it is for shareholders to exercise their voting right. This index is the antidirector right index constructed by La Porta et al. (1998). This index is formed by adding 1 when (1) the country allows share holders to mail their proxy vote to the firm, (2) shareholders are not required to deposit their shares prior to the general shareholders' meeting, (3) cumulative voting or proportional representation of minorities in the board of directors is allowed, (4) an oppressed minorities mechanism is in place, (5) the minimum percentage of share capital that entitles a shareholder to call for an extraordinary shareholders' meeting is less than or equal to 10 percent (the sample median), or (6) share holders have preemptive rights that can be waived only by a shareholders' vote. The index ranges from zero to six, with higher scores for stronger shareholder rights.

- Efficiency of the judicial system is the index ranging from zero to ten to represent the average of investors' assessment of conditions of the judicial system in each country between 1980 and 1983. This index is based on LaPorta et al. (1998, 2000, 2004), with higher scores implying greater law enforcement. Source: International Country Risk Guide.

- Rule of law measures the extent to which agents have confidence in and abide by the rules of society in year 2000 . These include perceptions of the incidence of both violent and non-violent crime, the effectiveness and predictability of the judiciary, and the enforceability of contracts, with higher scores implying greater law enforcement. Source: Kaufmann et al. (2004).

- Corruption index measures "the exercise of public power for private gain" in year 2000. It captures aspects ranging from the frequency of additional payments to get things done to the effects of corruption on the business environment, with higher scores implying greater law enforcement. Source Kaufmann et al. (2004).

- External Cap/GDP ratio is the average of the ratio of stock market capitalization held by small shareholders to gross domestic product for the period 1996-2000. The stock market capitalization held by small shareholders is computed as the product of the aggregate stock market capitalization and the average percentage of common shares not owned by the top three shareholders in the ten largest non-financial, privately-owned domestic firms in a given country. A firm is considered privately-owned if the State is not a known shareholder in it. This ratio is based on La Porta et al. (2004) and used to measure the importance of equity market in each country, with the higher values indicating the greater importance of the stock market. Source: La Porta et al. (1999), Hartland-Peel (1996) for Kenya, Bloomberg and various annual reports for Ecuador, Jordan, and Uruguay.

- Domestic Firms/Pop ratio is the ratio of the number of domestic firms listed in a given country to its population (in millions) for the period 1996-2000. This ratio is based on La Porta et al. (2004) and used to measure the importance of equity market in each country, with the higher values indicating the greater importance of the stock market. Source: International Finance Corporation: Emerging Markets Database (2001) and World Bank (2001).

- IPOs/GDP ratio is the ratio of the equity issued by newly-listed firms in a given country (in thousands) to its gross domestic product (in millions) for the period of 1996-2000. This ratio is based on La Porta et al. (2004) and used to measure the importance of equity market in each country, with the higher values indicating the greater importance of the stock market. Source: Securities Data Corporation, World Bank (2001).

- The ownership concentration is measured as the average percentage of common shares owned by the top three shareholders in the ten largest nonfinancial, privately-owned domestic firms in a given country. A firm is considered privately-owned if the State is not a known shareholder in it. This percentage is based on La Porta et al. (2004) and implies the legal protection, with higher concentration for poor legal protect. Source: La Porta et al. (1999), Hartland-Peel (1996) for Kenya, Bloomberg and various annual reports for Ecuador, Jordan, and Uruguay. 
TABLE 3

Sample Country's Mean Accounting Variables

Panel A: Main accounting variables (scaled by lagged total assets) used to calculate each earnings attribute

\begin{tabular}{|c|c|c|c|c|c|c|c|c|c|c|c|}
\hline Country & Legal Origin & Legal Tradition & $\mathrm{N}$ & EARN & EARN $_{t-1}$ & $\mathrm{CFO}$ & $\mathrm{CFO}_{\mathrm{t}-1}$ & $\mathrm{CFO}_{\mathrm{t}+1}$ & TCA & $\Delta \mathrm{REV}$ & PPE \\
\hline Australia & English & $\mathrm{CM}$ & 1,290 & -0.03 & -0.05 & 0.01 & -0.01 & 0.01 & 0.01 & 0.02 & 0.62 \\
\hline Austria & German & $\mathrm{CD}$ & 281 & 0.02 & 0.01 & 0.06 & 0.06 & 0.07 & 0.02 & 0.10 & 0.86 \\
\hline Belgium & French & $\mathrm{CD}$ & 424 & 0.03 & 0.02 & 0.07 & 0.07 & 0.08 & 0.02 & 0.14 & 0.74 \\
\hline Brazil & French & $\mathrm{CD}$ & 595 & 0.02 & 0.02 & 0.05 & 0.04 & 0.07 & 0.02 & 0.11 & 0.87 \\
\hline Canada & English & $\mathrm{CM}$ & 1,847 & -0.03 & -0.03 & 0.03 & 0.02 & 0.03 & 0.01 & 0.12 & 0.92 \\
\hline Chile & French & $\mathrm{CD}$ & 433 & 0.05 & 0.05 & 0.08 & 0.08 & 0.09 & 0.01 & 0.05 & 0.95 \\
\hline Denmark & Scandinavian & $\mathrm{CD}$ & 456 & 0.03 & 0.02 & 0.05 & 0.05 & 0.08 & 0.03 & 0.13 & 0.69 \\
\hline Finland & Scandinavian & $\mathrm{CD}$ & 491 & 0.05 & 0.05 & 0.08 & 0.09 & 0.09 & 0.03 & 0.19 & 0.67 \\
\hline France & French & $\mathrm{CD}$ & 2,299 & 0.03 & 0.03 & 0.06 & 0.06 & 0.07 & 0.02 & 0.17 & 0.46 \\
\hline Germany & German & $\mathrm{CD}$ & 2,421 & -0.03 & -0.01 & 0.01 & 0.04 & 0.00 & 0.05 & 0.20 & 0.70 \\
\hline Greece & French & $\mathrm{CD}$ & 316 & 0.08 & 0.07 & 0.06 & 0.08 & 0.09 & 0.07 & 0.17 & 0.68 \\
\hline Hong Kong & English & $\mathrm{CM}$ & 543 & 0.00 & -0.02 & 0.03 & 0.02 & 0.02 & 0.00 & -0.01 & 0.50 \\
\hline India & English & $\mathrm{CM}$ & 1,019 & 0.08 & 0.07 & 0.10 & 0.90 & 0.12 & 0.02 & 0.13 & 0.72 \\
\hline Indonesia & French & $\mathrm{CD}$ & 952 & 0.00 & -0.01 & 0.03 & 0.03 & -0.03 & 0.01 & 0.19 & 0.69 \\
\hline Italy & French & $\mathrm{CD}$ & 771 & 0.02 & 0.02 & 0.05 & 0.05 & 0.03 & 0.02 & 0.10 & 0.51 \\
\hline Japan & German & $\mathrm{CD}$ & 16,461 & 0.02 & 0.01 & 0.03 & 0.03 & 0.03 & 0.01 & 0.04 & 0.65 \\
\hline Malaysia & English & $\mathrm{CM}$ & 2,302 & 0.02 & 0.02 & 0.05 & 0.05 & 0.05 & 0.01 & 0.03 & 0.64 \\
\hline Mexico & French & $\mathrm{CD}$ & 347 & 0.06 & 0.05 & 0.09 & 0.09 & 0.10 & 0.01 & 0.15 & 0.90 \\
\hline Netherlands & French & $\mathrm{CD}$ & 746 & 0.04 & 0.03 & 0.07 & 0.07 & 0.09 & 0.03 & 0.23 & 0.67 \\
\hline Norway & Scandinavian & $\mathrm{CD}$ & 527 & -0.02 & -0.01 & 0.04 & 0.03 & -0.04 & 0.01 & 0.17 & 0.62 \\
\hline Philippines & French & $\mathrm{CD}$ & 505 & -0.01 & -0.03 & 0.02 & 0.01 & 0.04 & 0.01 & 0.07 & 0.74 \\
\hline Singapore & English & $\mathrm{CM}$ & 1,302 & 0.02 & 0.02 & 0.05 & 0.05 & 0.05 & 0.01 & 0.06 & 0.59 \\
\hline South Africa & English & $\mathrm{CM}$ & 278 & 0.17 & 0.09 & 0.18 & 0.10 & 0.10 & 0.04 & 0.53 & 0.67 \\
\hline South Korea & German & $\mathrm{CD}$ & 748 & 0.03 & 0.02 & 0.07 & 0.05 & 0.07 & 0.01 & 0.21 & 0.64 \\
\hline Spain & French & $\mathrm{CD}$ & 551 & 0.05 & 0.05 & 0.08 & 0.08 & 0.10 & 0.02 & 0.20 & 0.81 \\
\hline Sweden & Scandinavian & $\mathrm{CD}$ & 960 & -0.06 & -0.05 & -0.01 & -0.01 & -0.04 & 0.02 & 0.21 & 0.48 \\
\hline Switzerland & German & $\mathrm{CD}$ & 869 & 0.04 & 0.03 & 0.08 & 0.08 & 0.09 & 0.01 & 0.08 & 0.74 \\
\hline Taiwan & German & $\mathrm{CD}$ & 909 & 0.05 & 0.04 & 0.07 & 0.07 & 0.09 & 0.02 & 0.12 & 0.63 \\
\hline Thailand & English & $\mathrm{CM}$ & 1,357 & 0.03 & 0.02 & 0.08 & 0.08 & 0.08 & 0.00 & 0.05 & 0.75 \\
\hline UK & English & $\mathrm{CM}$ & 3,230 & 0.01 & 0.01 & 0.06 & 0.06 & 0.05 & 0.01 & 0.12 & 0.63 \\
\hline USA & English & $\mathrm{CM}$ & 12,380 & -0.03 & -0.02 & 0.02 & 0.02 & -0.02 & 0.01 & 0.16 & 0.64 \\
\hline
\end{tabular}


TABLE 3 (Continued)

Sample Country's Mean Accounting Variables

Panel B: Earnings attribute variables (raw and rank data) used in this study

\begin{tabular}{|c|c|c|c|c|c|c|c|c|c|c|}
\hline Country & Legal Origin & Legal Tradition & Stdresid & Persist & Pred & Smooth & R_Stdresid & R_Persist & R_Pred & R_Smooth \\
\hline Australia & English & $\mathrm{CM}$ & 0.094 & 0.521 & 0.199 & 1.150 & 5.00 & 8.86 & 3.57 & 21.43 \\
\hline Austria & German & $\mathrm{CD}$ & 0.051 & 0.578 & 0.073 & 1.507 & 22.43 & 11.71 & 19.71 & 12.86 \\
\hline Belgium & French & $\mathrm{CD}$ & 0.059 & 0.603 & 0.081 & 1.415 & 17.29 & 13.29 & 16.71 & 13.00 \\
\hline Brazil & French & $\mathrm{CD}$ & 0.040 & 0.789 & 0.058 & 1.352 & 25.86 & 15.43 & 21.71 & 14.14 \\
\hline Canada & English & $\mathrm{CM}$ & 0.079 & 0.810 & 0.162 & 1.072 & 10.86 & 17.29 & 6.43 & 23.86 \\
\hline Chile & French & $\mathrm{CD}$ & 0.034 & 0.919 & 0.051 & 1.433 & 28.71 & 19.86 & 25.86 & 12.43 \\
\hline Denmark & Scandinavian & $\mathrm{CD}$ & 0.063 & 0.773 & 0.107 & 1.343 & 15.14 & 16.43 & 14.57 & 15.00 \\
\hline Finland & Scandinavian & $\mathrm{CD}$ & 0.060 & 0.934 & 0.090 & 1.240 & 17.00 & 20.43 & 16.57 & 17.57 \\
\hline France & French & $\mathrm{CD}$ & 0.061 & 0.841 & 0.071 & 1.350 & 16.00 & 18.86 & 19.43 & 13.57 \\
\hline Germany & German & $\mathrm{CD}$ & 0.105 & 1.031 & 0.144 & 1.285 & 4.14 & 19.00 & 9.86 & 15.86 \\
\hline Greece & French & $\mathrm{CD}$ & 0.054 & 0.850 & 0.066 & 2.226 & 20.14 & 19.43 & 23.14 & 6.14 \\
\hline Hong Kong & English & $\mathrm{CM}$ & 0.078 & 0.361 & 0.197 & 1.108 & 9.00 & 6.57 & 5.71 & 23.57 \\
\hline India & English & $\mathrm{CM}$ & 0.051 & 1.085 & 0.045 & 1.356 & 21.57 & 25.86 & 27.00 & 13.29 \\
\hline Indonesia & French & $\mathrm{CD}$ & 0.103 & 0.779 & 0.125 & 1.315 & 4.00 & 14.43 & 12.71 & 16.43 \\
\hline Italy & French & $\mathrm{CD}$ & 0.047 & 0.668 & 0.059 & 1.506 & 23.57 & 12.71 & 22.00 & 7.57 \\
\hline Japan & German & $\mathrm{CD}$ & 0.031 & 0.787 & 0.032 & 1.450 & 29.57 & 17.14 & 30.57 & 9.00 \\
\hline Malaysia & English & $\mathrm{CM}$ & 0.074 & 0.705 & 0.081 & 1.298 & 10.00 & 16.29 & 17.43 & 18.29 \\
\hline Mexico & French & $\mathrm{CD}$ & 0.038 & 0.564 & 0.076 & 1.339 & 27.00 & 10.43 & 18.00 & 14.29 \\
\hline Netherlands & French & $\mathrm{CD}$ & 0.072 & 1.150 & 0.121 & 1.161 & 11.86 & 22.14 & 16.14 & 19.86 \\
\hline Norway & Scandinavian & $\mathrm{CD}$ & 0.090 & 0.649 & 0.313 & 1.061 & 7.71 & 10.86 & 3.29 & 23.14 \\
\hline Philippines & French & $\mathrm{CD}$ & 0.071 & 0.683 & 0.112 & 1.862 & 14.71 & 13.57 & 11.71 & 19.57 \\
\hline Singapore & English & $\mathrm{CM}$ & 0.065 & 0.738 & 0.074 & 1.392 & 13.43 & 14.71 & 17.71 & 13.00 \\
\hline South Africa & English & $\mathrm{CM}$ & 0.068 & 0.414 & 0.128 & 1.608 & 15.14 & 9.43 & 9.86 & 12.57 \\
\hline South Korea & German & $\mathrm{CD}$ & 0.061 & 0.736 & 0.081 & 2.363 & 18.00 & 15.86 & 18.71 & 9.43 \\
\hline Spain & French & $\mathrm{CD}$ & 0.051 & 0.787 & 0.052 & 1.753 & 19.57 & 16.14 & 22.86 & 6.14 \\
\hline Sweden & Scandinavian & $\mathrm{CD}$ & 0.081 & 0.916 & 0.166 & 1.186 & 8.57 & 18.71 & 9.43 & 21.14 \\
\hline Switzerland & German & $\mathrm{CD}$ & 0.046 & 0.802 & 0.058 & 1.352 & 24.00 & 16.43 & 22.86 & 16.29 \\
\hline Taiwan & German & $\mathrm{CD}$ & 0.049 & 0.894 & 0.061 & 1.246 & 21.43 & 20.43 & 21.00 & 17.43 \\
\hline Thailand & English & $\mathrm{CM}$ & 0.061 & 0.661 & 0.074 & 1.316 & 15.86 & 13.29 & 19.14 & 14.00 \\
\hline UK & English & $\mathrm{CM}$ & 0.074 & 0.849 & 0.133 & 1.034 & 10.86 & 18.29 & 8.57 & 26.14 \\
\hline USA & English & $\mathrm{CM}$ & 0.091 & 0.968 & 0.213 & 0.946 & 7.57 & 22.14 & 3.71 & 29.00 \\
\hline
\end{tabular}

Note: these earnings attribute variables are based on the average of a country's variables obtained from cross-section of data per country per year (1996-2002). 
TABLE 3 (Continued)

Sample Country's Mean Accounting Variables

Panel C: Country-year correlation matrix of earnings attributes

\begin{tabular}{|c|c|c|c|c|c|c|c|c|}
\hline & \multicolumn{4}{|c|}{ Predicted Sign } & \multicolumn{4}{|c|}{ Correlation Coefficient $^{\text {ж }}$} \\
\hline Stdresid & & - & + & + & & $0.202 * * *$ & $0.751 * * *$ & $-0.268 * * *$ \\
\hline Persist & - & & - & - & 0.042 & & $0.134 * *$ & $-0.130 * *$ \\
\hline Pred & + & - & & + & $0.851 * * *$ & $-0.141 * *$ & & $-0.304 * * *$ \\
\hline Smooth & + & - & + & & $-0.461 * * *$ & -0.037 & $-0.579 * * *$ & \\
\hline
\end{tabular}

ж Pearson correlation matrix is presented in the upper half and Spearman-rank correlation matrix is presented in the lower half. $* * *, * *, *$ denote $1 \%$ significance, $5 \%$ significance, and $10 \%$ significance, respectively (two-tailed). 
TABLE 3 (Concluded)

Definitions:

\section{Sample Country's Mean Accounting Variables}

- Accruals quality is measured by the standard deviation of the estimated residuals (Stdresid) from pooled firm-year regressions per country and year of changes in working capital on last year, present, and one-year ahead cash flows from operations, consistent with Dechow and Dichev (2002) and McNichols (2002).

$$
\begin{aligned}
\frac{\text { TCA }_{t}}{\text { TotalAsset }_{t-1}} & =b_{0}+b_{1} * \frac{C F O_{t-1}}{\text { TotalAsset }_{t-1}}+b_{2} * \frac{C F O_{t}}{\text { TotalAsset }_{t-1}}+ \\
& b_{3} * \frac{C F O_{t+1}}{\text { TotalAsset }_{t-1}}+b_{4} * \frac{\Delta R E V_{t}}{\text { TotalAsset }_{t-1}}+b_{5} * \frac{P P E_{t}}{\text { TotalAsset }_{t-1}}+\varepsilon_{t}
\end{aligned}
$$

- Earnings persistence is the slope coefficient estimates (Persist) from pooled firm-year regressions per country and year of current earnings on last year earnings.

$$
\frac{\text { Earn }_{t}}{\text { TotalAssets }_{t-1}}=\alpha+\delta_{1} * \frac{\text { Earn }_{t-1}}{\text { TotalAsset }_{t-1}}+v_{t}
$$

- Earnings predictability is the square root of the error variance from earnings persistence equation.

$$
\operatorname{Pred}_{\mathrm{j}, \mathrm{t}}=\sqrt{\sigma^{2}\left(v_{1}\right)_{t}}
$$

- Earnings smoothness is the ratio of the country-year standard deviation of operating cash flows to the standard deviation of earnings.

$$
\text { Smooth }_{\mathrm{j}, \mathrm{t}}=\frac{\sigma\left(\mathrm{CFO}_{j, t} / \text { TotalAssets }_{j, t-1}\right)}{\sigma\left(\text { Earn }_{j, t} / \text { TotalAssets }_{j, t-1}\right)}
$$

- R_Stdresid is a descending rank score of "Stdresid", with the high rank score (31) implying high earnings quality.

- R_Persist is an ascending rank score of "Persist", with the high rank score (31) implying high earnings quality.

- R_ Pred is a descending rank score of "Pred", with the high rank score (31) implying high earnings quality.

- R_Smooth is a descending rank score of "Smooth", with the high rank score (31) implying high earnings quality.

- Legal tradition refers to a common law tradition (CM) or a code law tradition (CD). 
TABLE 4

Institutional Clusters

The table presents results from a k-means cluster analysis using three distinct clusters and eight investor protection proxies from La Porta et al. (2004). See Table 1 for details. The investor protection proxies are standardized to $\mathrm{z}$-scores when this study performs a k-

means cluster analysis. Panel A reports the means of the investor protection variables by cluster. Panel B reports the cluster membership for the 31 sample countries based on the cluster analysis performed on the proxies in Panel A. CD (CM) indicates a code law (common law) tradition. Panel $\mathrm{C}$ reports a comparison of the cluster membership of countries in this study and that in Leuz et al. (2003)

Panel A: Mean values of institutional characteristics by cluster

\begin{tabular}{|c|c|c|c|}
\hline Institutional Variables & Cluster 1 & Cluster 2 & Cluster 3 \\
\hline -Antidirector Rights & 4.43 & 2.64 & 2.80 \\
\hline Tests of differences between clusters & $\mathrm{C} 1$ vs. $\mathrm{C} 2 * * *$ & $\mathrm{C} 2$ vs. $\mathrm{C} 3$ & $\mathrm{C} 1$ vs. $\mathrm{C} 3 * * *$ \\
\hline -Efficiency of Judicial System & 9.89 & 8.73 & 5.90 \\
\hline Tests of differences between clusters & $\mathrm{C} 1$ vs. $\mathrm{C} 2 * * *$ & $\mathrm{C} 2$ vs. $\mathrm{C} 3 * * *$ & $\mathrm{C} 1$ vs. $\mathrm{C} 3 * * *$ \\
\hline - Rule of Law & 1.95 & 1.68 & 0.13 \\
\hline Tests of differences between clusters & $\mathrm{C} 1$ vs. $\mathrm{C} 2 * * *$ & $\mathrm{C} 2$ vs. $\mathrm{C} 3 * * *$ & $\mathrm{C} 1$ vs. $\mathrm{C} 3 * * *$ \\
\hline - Corruption Index & 2.10 & 1.70 & -0.01 \\
\hline Tests of differences between clusters & $\mathrm{C} 1$ vs. $\mathrm{C} 2 * * *$ & $\mathrm{C} 2$ vs. $\mathrm{C} 3 * * *$ & $\mathrm{C} 1$ vs. $\mathrm{C} 3 * * *$ \\
\hline - External Cap/GDP Ratio & 0.96 & 0.54 & 0.30 \\
\hline Tests of differences between clusters & $\mathrm{C} 1$ vs. $\mathrm{C} 2 * * *$ & $\mathrm{C} 2$ vs. $\mathrm{C} 3 * * *$ & $\mathrm{C} 1$ vs. $\mathrm{C} 3 * * *$ \\
\hline - Domestic Firms/Pop Ratio & 64.04 & 22.11 & 10.14 \\
\hline Tests of differences between clusters & $\mathrm{C} 1$ vs. $\mathrm{C} 2 * * *$ & $\mathrm{C} 2$ vs. $\mathrm{C} 3 * * *$ & $\mathrm{C} 1$ vs. $\mathrm{C} 3 * * *$ \\
\hline - IPOs/GDP Ratio & 8.61 & 3.37 & 2.85 \\
\hline Tests of differences between clusters & $\mathrm{C} 1$ vs. $\mathrm{C} 2 * * *$ & $\mathrm{C} 2$ vs. $\mathrm{C} 3$ & $\mathrm{C} 1$ vs. $\mathrm{C} 3 * * *$ \\
\hline - Ownership Concentration & 0.34 & 0.39 & 0.55 \\
\hline \multirow[t]{2}{*}{ Tests of differences between clusters } & $\mathrm{C} 1$ vs. $\mathrm{C} 2 * * *$ & $\mathrm{C} 2$ vs. $\mathrm{C} 3$ **** & $\mathrm{C} 1$ vs. $\mathrm{C} 3$ *** \\
\hline & Outsider features & $\leftrightarrow$ & Insider Features \\
\hline
\end{tabular}

Panel B: Cluster membership of countries (sorted in alphabet order)

\begin{tabular}{ccc}
\hline Cluster 1 & Cluster 2 & Cluster 3 \\
\hline Australia (CM) & Austria (CD) & Brazil (CD) \\
Canada (CM) & Belgium (CD) & Greece (CD) \\
Hong Kong (CM) & Chile (CD) & India (CM) \\
Singapore (CM) & Denmark (CD) & Indonesia (CD) \\
Sweden (CD) & Finland (CD) & Italy (CD) \\
UK (CM) & France (CD) & Malaysia (CM) \\
USA (CM) & Germany (CD) & Mexico (CD) \\
& Japan (CD) & Philippines (CD) \\
& Netherlands (CD) & South Africa (CM) \\
& Norway (CD) & Thailand (CM) \\
& South Korea (CD) & \\
& Spain (CD) & \\
& Switzerland (CD) & \\
& Taiwan (CD) \\
& & \\
& &
\end{tabular}


TABLE 4 (Concluded)

Institutional Clusters

Panel C: Cluster membership of countries compared to that of Leuz et al. (2003)

\begin{tabular}{|c|c|c|c|c|}
\hline \multirow[t]{2}{*}{ Country } & \multirow[t]{2}{*}{ Legal Origin } & \multirow[t]{2}{*}{ Legal Tradition } & \multicolumn{2}{|c|}{ Cluster Classification } \\
\hline & & & This study & Leuz et al. (2003) \\
\hline Australia & English & $\mathrm{CM}$ & Cluster 1 & Cluster 1 \\
\hline Austria & German & $\mathrm{CD}$ & Cluster 2 & Cluster 2 \\
\hline Belgium & French & $\mathrm{CD}$ & Cluster 2 & Cluster 2 \\
\hline Brazil & French & $\mathrm{CD}$ & Cluster 3 & N/A \\
\hline Canada & English & $\mathrm{CM}$ & Cluster 1 & Cluster 1 \\
\hline Chile & French & $\mathrm{CD}$ & Cluster 2 & N/A \\
\hline Denmark & Scandinavian & $\mathrm{CD}$ & Cluster 2 & Cluster 2 \\
\hline Finland & Scandinavian & $\mathrm{CD}$ & Cluster 2 & Cluster 2 \\
\hline France & French & $\mathrm{CD}$ & Cluster 2 & Cluster 2 \\
\hline Germany & German & $\mathrm{CD}$ & Cluster 2 & Cluster 2 \\
\hline Greece & French & $\mathrm{CD}$ & Cluster3 & Cluster 3 \\
\hline Hong Kong & English & $\mathrm{CM}$ & Cluster 1 & Cluster 1 \\
\hline India & English & $\mathrm{CM}$ & Cluster 3 & Cluster 3 \\
\hline Indonesia & French & $\mathrm{CD}$ & Cluster 3 & Cluster 3 \\
\hline Italy & French & $\mathrm{CD}$ & Cluster 3 & Cluster 3 \\
\hline Japan & German & $\mathrm{CD}$ & Cluster 2 & Cluster 2 \\
\hline Malaysia & English & $\mathrm{CM}$ & Cluster 3 & Cluster 1 \\
\hline Mexico & French & $\mathrm{CD}$ & Cluster 3 & N/A \\
\hline Netherlands & French & $\mathrm{CD}$ & Cluster 2 & Cluster 2 \\
\hline Norway & Scandinavian & $\mathrm{CD}$ & Cluster 2 & Cluster 1 \\
\hline Philippines & French & $\mathrm{CD}$ & Cluster 3 & Cluster 3 \\
\hline Singapore & English & $\mathrm{CM}$ & Cluster 1 & Cluster 1 \\
\hline South Africa & English & $\mathrm{CM}$ & Cluster 3 & Cluster 2 \\
\hline South Korea & German & CD & Cluster 2 & Cluster 3 \\
\hline Spain & French & $\mathrm{CD}$ & Cluster 2 & Cluster 3 \\
\hline Sweden & Scandinavian & $\mathrm{CD}$ & Cluster 1 & Cluster 2 \\
\hline Switzerland & German & $\mathrm{CD}$ & Cluster 2 & Cluster 2 \\
\hline Taiwan & German & $\mathrm{CD}$ & Cluster 2 & Cluster 2 \\
\hline Thailand & English & $\mathrm{CM}$ & Cluster 3 & Cluster 3 \\
\hline United Kingdom & English & $\mathrm{CM}$ & Cluster 1 & Cluster 1 \\
\hline USA & English & $\mathrm{CM}$ & Cluster 1 & Cluster 1 \\
\hline
\end{tabular}

Definitions:

- Legal origin identifies the legal origin of the company law or commercial code of each country based on La Porta et al. (1997)

- Legal tradition equals CM if common law and equals CD if code law. This classification is based on La Porta et al. (1997). 
TABLE 5

Institutional Clusters and Earnings Attributes

The table presents mean values of four accounting based-earnings attributes across three distinct clusters based on a k-means cluster analysis. See Table 2 for details. Panels A1A4 report the cluster membership for the 31 sample countries based on cluster analysis performed on the investor protection proxies in Table 2. Countries in each cluster are sorted by the mean-rank scores of accruals quality (Panel A1), earnings persistence (Panel A2), earning predictability (Panel A3), and earnings smoothness (Panel A4), respectively. See Table 3, Panel B for details about these mean-rank scores of each earnings attribute. Panel B reports the means by cluster of raw and rank data of each earnings attribute.

Panel A1: Cluster membership of countries sorted by mean-rank accruals quality score [Country rank value is presented in the parenthesis]

\begin{tabular}{|c|c|c|c|}
\hline & Cluster 1 & Cluster 2 & Cluster 3 \\
\hline & Singapore (13.43) & Japan (29.57) & Mexico (27.00) \\
\hline & UK (10.86) & Chile (28.71) & Brazil (25.86) \\
\hline & Canada (10.86) & Switzerland (24.00) & Italy (23.57) \\
\hline & Hong Kong (9.00) & Austria (22.43) & India (21.57) \\
\hline & Sweden (8.57) & Taiwan (21.43) & Greece (20.14) \\
\hline & USA (7.57) & Spain (19.57) & Thailand (15.86) \\
\hline & Australia (5.00) & South Korea (18.00) & South Africa (15.14) \\
\hline & & Belgium (17.29) & Philippines (14.71) \\
\hline & & Finland (17.00) & Malaysia (10.00) \\
\hline & & France (16.00) & Indonesia (4.00) \\
\hline & & Denmark (15.14) & \\
\hline & & Netherlands (11.86) & \\
\hline & & Norway (7.71) & \\
\hline & & Germany (4.14) & \\
\hline Mean-Rank Values (rank) & $9.33\left(3^{\mathrm{rd}}\right)$ & $18.06\left(1^{\mathrm{st}}\right)$ & $17.79\left(2^{\text {nd }}\right)$ \\
\hline
\end{tabular}

Note: Mean-rank accruals quality score is the average of country-year accruals quality rank variables, with higher rank implying high earnings quality (i.e., Japan has the highest average-rank score of 29.57;

Indonesia has the lowest average-rank score of 4.00). 


\section{TABLE 5 (Continued) \\ Institutional Clusters and Earnings Attributes}

Panel A2: Cluster membership of countries sorted by mean-rank earnings persistence score [Country rank value is presented in the parenthesis]

\begin{tabular}{|c|c|c|c|}
\hline & Cluster 1 & Cluster 2 & Cluster 3 \\
\hline & USA (22.14) & Netherlands (22.14) & India (25.86) \\
\hline & Sweden (18.71) & Finland (20.43) & Greece (19.43) \\
\hline & UK (18.29) & Taiwan (20.43) & Malaysia (16.29) \\
\hline & Canada (17.29) & Chile (19.86) & Brazil (15.43) \\
\hline & Singapore (14.71) & Germany (19.00) & Indonesia (14.43) \\
\hline & Australia (8.86) & France (18.86) & Philippines (13.57) \\
\hline & Hong Kong (6.57) & Japan (17.14) & Thailand (13.29) \\
\hline & & Switzerland (16.43) & Italy (12.71) \\
\hline & & Denmark (16.43) & Mexico (10.43) \\
\hline & & Spain (16.14) & South Africa (9.43) \\
\hline & & South Korea (15.86) & \\
\hline & & Belgium (13.29) & \\
\hline & & Austria (11.71) & \\
\hline & & Norway (10.86) & \\
\hline Mean-Rank Values (rank) & $15.22\left(3^{\text {rd }}\right)$ & $17.04\left(1^{\mathrm{st}}\right)$ & $15.09\left(2^{\text {nd }}\right)$ \\
\hline
\end{tabular}

Note: Mean-rank earnings persistence score is the average of country-year earning persistence rank variables, with higher rank implying less earnings management or high earnings quality (i.e., India has the highest average-rank score of 25.86; Hong Kong has the lowest average-rank score of 6.57).

Panel A3: Cluster membership of countries sorted by mean-rank earnings predictability score [Country rank value is presented in the parenthesis]

\begin{tabular}{|c|c|c|c|}
\hline & Cluster 1 & Cluster 2 & Cluster 3 \\
\hline & Singapore (17.71) & Japan (30.57) & India (27.00) \\
\hline & Sweden (9.43) & Chile (25.86) & Greece (23.14) \\
\hline & UK (8.57) & Switzerland (22.86) & Italy $(22.00)$ \\
\hline & Canada (6.43) & Spain (22.86) & Brazil (21.71) \\
\hline & Hong Kong (5.71) & Taiwan (21.00) & Thailand (19.14) \\
\hline & USA (3.71) & Austria (19.71) & Mexico (18.00) \\
\hline & Australia (3.57) & France (19.43) & Malaysia (17.43) \\
\hline & & South Korea (18.71) & Indonesia (12.71) \\
\hline & & Belgium (16.71) & Philippines (11.71) \\
\hline & & Finland (16.57) & South Africa (9.86) \\
\hline & & Netherlands (16.14) & \\
\hline & & Denmark (14.57) & \\
\hline & & Germany (9.86) & \\
\hline & & Norway (3.29) & \\
\hline Mean-Rank Values (rank) & $7.88\left(3^{\text {rd }}\right)$ & $18.44\left(1^{\mathrm{st}}\right)$ & $18.27\left(2^{\text {nd }}\right)$ \\
\hline
\end{tabular}

Note: Mean-rank earnings predictability score is the average of country-year earning predictability rank variables, with higher rank implying less earnings management or high earnings quality (i.e., Japan has the highest average-rank score of 30.57; Norway has the lowest average-rank score of 3.29). 


\section{TABLE 5 (Continued) \\ Institutional Clusters and Earnings Attributes}

Panel A4: Cluster membership of countries sorted by mean-rank earnings smoothness score [Country rank value is presented in the parenthesis]

\begin{tabular}{|c|c|c|c|}
\hline & Cluster 1 & Cluster 2 & Cluster 3 \\
\hline & USA (29.00) & Norway (23.14) & Philippines (19.57) \\
\hline & UK (26.14) & Netherlands (19.86) & Malaysia (18.29) \\
\hline & Canada (23.86) & Taiwan (17.43) & Indonesia (16.43) \\
\hline & Hong Kong (23.57) & Finland (17.57) & Mexico (14.29) \\
\hline & Australia (21.43) & Switzerland (16.29) & Brazil (14.14) \\
\hline & Sweden (21.14) & Germany (15.86) & Thailand (14.00) \\
\hline & Singapore (13.00) & Denmark (15.00) & India (13.29) \\
\hline & & France (13.57) & South Africa (12.57) \\
\hline & & Belgium (13.00) & Italy (7.57) \\
\hline & & Austria (12.86) & Greece (6.14) \\
\hline & & Chile (12.43) & \\
\hline & & South Korea (9.43) & \\
\hline & & Japan (9.00) & \\
\hline & & Spain (6.14) & \\
\hline Mean-Rank Values (rank) & $22.59\left(1^{\mathrm{st}}\right)$ & $14.40\left(2^{\text {nd }}\right)$ & $13.63\left(3^{\text {rd }}\right)$ \\
\hline
\end{tabular}

Note: Mean-rank earnings smoothness score is the average of country-year earning smoothness rank variables, with higher rank implying less earnings management or high earnings quality (i.e., USA has the highest average-rank score of 29.00; Spain and Greece have the lowest average-rank score of 6.14).

Panel B: Mean values of earnings attributes by cluster

\begin{tabular}{|c|c|c|c|}
\hline Earnings Attributes & Cluster 1 & Cluster 2 & Cluster 3 \\
\hline \multicolumn{4}{|l|}{ Raw data: } \\
\hline - Accruals quality & 0.08 & 0.06 & 0.06 \\
\hline Tests of differences between clusters & $\mathrm{C} 1$ vs. $\mathrm{C} 2 * * *$ & $\mathrm{C} 2$ vs. $\mathrm{C} 3$ & $\mathrm{C} 1$ vs. $\mathrm{C} 3 * * *$ \\
\hline - Earnings Persistence & 0.74 & 0.82 & 0.72 \\
\hline Tests of differences between clusters & $\mathrm{C} 1$ vs. $\mathrm{C} 2$ & $\mathrm{C} 2$ vs. C3 & $\mathrm{C} 1$ vs. $\mathrm{C} 3$ \\
\hline - Earnings Predictability & 0.16 & 0.10 & 0.08 \\
\hline Tests of differences between clusters & $\mathrm{C} 1$ vs. $\mathrm{C} 2 * * *$ & C2 vs. C3 & $\mathrm{C} 1$ vs. $\mathrm{C} 3 * * *$ \\
\hline - Earnings Smoothness & 1.13 & 1.43 & 1.52 \\
\hline Tests of differences between clusters & $\mathrm{C} 1$ vs. $\mathrm{C} 2 * * *$ & $\mathrm{C} 2$ vs. C3 & $\mathrm{C} 1$ vs. $\mathrm{C} 3 * * *$ \\
\hline $\mathrm{N}$ & 49 & 98 & 70 \\
\hline \multicolumn{4}{|l|}{ Rank score: } \\
\hline - Accruals quality & 9.33 & 18.06 & 17.79 \\
\hline Tests of differences between clusters & $\mathrm{C} 1$ vs. $\mathrm{C} 2 * * *$ & $\mathrm{C} 2$ vs. C3 & $\mathrm{C} 1$ vs. $\mathrm{C} 3 * * *$ \\
\hline - Earnings Persistence & 15.22 & 17.04 & 15.09 \\
\hline Tests of differences between clusters & $\mathrm{C} 1$ vs. $\mathrm{C} 2$ & $\mathrm{C} 2$ vs. $\mathrm{C} 3$ & $\mathrm{C} 1$ vs. $\mathrm{C} 3$ \\
\hline - Earnings Predictability & 7.88 & 18.44 & 18.27 \\
\hline Tests of differences between clusters & $\mathrm{C} 1$ vs. $\mathrm{C} 2 * * *$ & $\mathrm{C} 2$ vs. C3 & $\mathrm{C} 1$ vs. $\mathrm{C} 3 * * *$ \\
\hline - Earnings Smoothness & 22.59 & 14.40 & 13.63 \\
\hline Tests of differences between clusters & $\mathrm{C} 1$ vs. $\mathrm{C} 2 * * *$ & C2 vs. C3 & $\mathrm{C} 1$ vs. $\mathrm{C} 3 * * *$ \\
\hline $\mathrm{N}$ & 49 & 98 & 70 \\
\hline
\end{tabular}


TABLE 5 (Concluded)

Institutional Clusters and Earnings Attributes

Accounting Variable Definitions:

- Accruals quality is measured by the standard deviation of the estimated residuals (Stdresid) from pooled firm-year regressions per country and year of changes in working capital on last year, present, and one-year ahead cash flows from operations, consistent with Dechow and Dichev (2002) and McNichols (2002).

$$
\begin{aligned}
\frac{\text { TCA }_{t}}{\text { TotalAsset }_{t-1}}= & b_{0}+b_{1} * \frac{C F O_{t-1}}{\text { TotalAsset }_{t-1}}+b_{2} * \frac{C F O_{t}}{\text { TotalAsset }_{t-1}}+ \\
& b_{3} * \frac{C F O_{t+1}}{\text { TotalAsset }_{t-1}}+b_{4} * \frac{\Delta R E V_{t}}{\text { TotalAsset }_{t-1}}+b_{5} * \frac{P P E_{t}}{\text { TotalAsset }_{t-1}}+\varepsilon_{t}
\end{aligned}
$$

- Earnings persistence is the slope coefficient estimates (Persist) from pooled firm-year regressions per country and year of current earnings on last year earnings.

$$
\frac{\text { Earn }_{t}}{\text { TotalAssets }_{t-1}}=\alpha+\delta_{1} * \frac{\text { Earn }_{t-1}}{\text { TotalAsset }_{t-1}}+v_{t}
$$

- Earnings predictability is the square root of the error variance from earnings persistence equation.

$\operatorname{Pred}_{\mathrm{j}, \mathrm{t}}=\sqrt{\sigma^{2}\left(v_{1}\right)_{t}}$

- Earnings smoothness is the ratio of the country-year standard deviation of operating cash flows to the standard deviation of earnings.

$$
\text { Smooth }_{\mathrm{j}, \mathrm{t}}=\frac{\sigma\left(\mathrm{CFO}_{j, t} / \text { TotalAssets }_{j, t-1}\right)}{\sigma\left(\text { Earn }_{j, t} / \text { TotalAssets }_{j, t-1}\right)}
$$

- R_Stdresid is a descending rank score of "Stdresid", with the high rank score (31) implying high earnings quality.

- R_Persist is an ascending rank score of "Persist", with the high rank score (31) implying high earnings quality.

- $\quad$ R_ Pred is a descending rank score of "Pred", with the high rank score (31) implying high earnings quality.

- R_Smooth is a descending rank score of "Smooth), with the high rank score (31) implying high earnings quality.

Note: All accounting variables are scaled by lagged total assets. 
TABLE 6

Country-Year Correlation Matrix

Panel A: Country-year correlation matrix between earnings attributes (raw data) and institutional characteristics

\begin{tabular}{|c|c|c|c|c|c|c|c|c|}
\hline & \multicolumn{4}{|c|}{ Predicted Sign } & \multicolumn{4}{|c|}{ Spearman Rank Correlation Coefficent* } \\
\hline & Stdresid & Persist & Pred & Smooth & Stdresid & Persist & Pred & Smooth \\
\hline InvRights & - & + & - & - & $0.126^{*}$ & 0.041 & $0.169 * * *$ & $-0.238 * * *$ \\
\hline JudicSys & - & + & - & - & $0.191 * * *$ & 0.049 & $0.216 * * *$ & $-0.282 * * *$ \\
\hline RuleofLaw & - & + & - & - & $0.168 * * *$ & 0.031 & $0.197 * * *$ & $-0.191 * * *$ \\
\hline Corruption & - & + & - & - & $0.182 * * *$ & 0.096 & $0.203 * * *$ & $-0.183 * * *$ \\
\hline ExtCap & - & + & - & - & $0.192 * * *$ & 0.072 & $0.197 * * *$ & $-0.294 * * *$ \\
\hline DoFirms & - & + & - & - & $0.260 * * *$ & -0.039 & $0.303 * * *$ & $-0.271 * * *$ \\
\hline IPOs & - & + & - & - & $0.262 * * *$ & 0.093 & $0.204 * * *$ & $-0.193 * * *$ \\
\hline Ownership & + & - & + & + & $-0.119 *$ & $-0.188 * * *$ & $-0.117 *$ & $0.262 * * *$ \\
\hline & & & & $\mathrm{N}$ & 217 & 217 & 217 & 217 \\
\hline
\end{tabular}

$* * *, * *, *$ denote $1 \%$ significance, $5 \%$ significance, and 10\% significance, respectively (two-tailed). 
TABLE 6 (Continued)

Country-Year Correlation Matrix

Panel B: Country-year correlation matrix between earnings attributes (rank score) and institutional characteristics

\begin{tabular}{|c|c|c|c|c|c|c|c|c|}
\hline & \multicolumn{4}{|c|}{ Predicted Sign } & \multicolumn{4}{|c|}{ Spearman Rank Correlation Coefficent* } \\
\hline & R_Stdresid & R_Persist & R_Pred & R_Smooth & R_Stdresid & R_Persist & R_Pred & R_Smooth \\
\hline InvRights & + & + & + & + & $-0.121 *$ & 0.050 & $-0.198 * * *$ & $0.259 * * *$ \\
\hline JudicSys & + & + & + & + & $-0.218 * * *$ & 0.058 & $-0.250 * * *$ & $0.298 * * *$ \\
\hline RuleofLaw & + & + & + & + & $-0.176 * * *$ & 0.029 & $-0.225 * * *$ & $0.213 * * *$ \\
\hline Corruption & + & + & + & + & $-0.202 * * *$ & 0.088 & $-0.236 * * *$ & $0.210 * * *$ \\
\hline ExtCap & + & + & + & + & $-0.207 * * *$ & 0.092 & $-0.231 * * *$ & $0.312 * * *$ \\
\hline DoFirms & + & + & + & + & $-0.257 * * *$ & -0.009 & $-0.311 * * *$ & $0.279 * * *$ \\
\hline IPOs & + & + & + & + & $-0.233 * * *$ & $0.128 *$ & $-0.177 * * *$ & $0.156^{* *}$ \\
\hline Ownership & - & - & - & - & $0.126^{*}$ & $-0.205 * * *$ & $0.124 *$ & $-0.250 * * *$ \\
\hline & & & & $\mathrm{N}$ & 217 & 217 & 217 & 217 \\
\hline
\end{tabular}

$* * *, * *, *$ denote $1 \%$ significance, $5 \%$ significance, and $10 \%$ significance, respectively (two-tailed).

Note: R_Stdresid, R_Persist, R_Pred, and R_Smooth are accruals quality, earnings persistence, earnings predictability, and earnings smoothness rank variables, respectively. R_Persist variable is an ascending rank "Persist" variable while the rest are descending rank variables, with higher rank implying high earnings quality (i.e. $31=$ highest quality; $1=$ lowest quality). 
Table 6 (Concluded)

Country-Year Correlation Matrix

Accounting Variable Definitions:

- Accruals quality is measured by the standard deviation of the estimated residuals (Stdresid) from pooled firm-year regressions per country and year of changes in working capital on last year, present, and one-year ahead cash flows from operations, consistent with Dechow and Dichev (2002) and McNichols (2002).

- Earnings persistence is the slope coefficient estimates (Persist) from pooled firm-year regressions per country and year of current earnings on last year earnings.

- Earnings predictability (Pred) is the square root of the error variance from earnings persistence equation.

- Earnings smoothness (Smooth) is the ratio of the country-year standard deviation of operating cash flows to the standard deviation of earnings.

- R_Stdresid is a descending rank score of "Stdresid", with the high rank score (31) implying high earnings quality.

- R_Persist is an ascending rank score of "Persist", with the high rank score (31) implying high earnings quality.

- R_Pred is a descending rank score of "Pred", with the high rank score (31) implying high earnings quality.

- R_Smooth is a descending rank score of "Smooth", with the high rank score (31) implying high earnings quality.

Investor Protection Variable Definitions:

- InvRights is the antidirector rights index.

- JudicSys is the efficiency of the judicial system index.

- RuleofLaw is the rule of law index, mentioned earlier.

- Corruption is the corruption index.

- ExtCap is the ratio of external capitalization to gross domestic product ratio.

- DoFirms is the ratio of the number of domestic firms to its population (in millions).

- IPOs is the ratio of the equity issued newly-listed firms in a given country (in thousands) to its gross domestic product (in millions).

- Ownership is the ownership concentration percentage.

Note: Full investor protection variable definitions are explained in Table 2. 
TABLE 7

Country-Year Regression Analysis Between Earnings Attributes and Investor Protection Proxies

Panel A: Accruals quality rank score (“R_Stdresid”) and institutional characteristic

\begin{tabular}{|c|c|c|c|c|c|c|c|c|c|}
\hline & Prediction & Model 1 & Model 2 & Model 3 & Model 4 & Model 5 & Model 6 & Model 7 & Model 8 \\
\hline \multirow[t]{2}{*}{ Intercept } & & $21.543 * * *$ & $27.903 * * *$ & $24.898 * * *$ & $24.465 * * *$ & $22.920 * * *$ & $22.336 * * *$ & $22.469 * * *$ & $19.432 * * *$ \\
\hline & & $(14.14)$ & $(10.97)$ & $(15.77)$ & $(16.23)$ & $(16.42)$ & (17.19) & $(16.85)$ & $(8.57)$ \\
\hline \multirow[t]{2}{*}{ InvRights } & + & 0.342 & & & & & & & \\
\hline & & $(.74)$ & & & & & & & \\
\hline \multirow[t]{2}{*}{ JudicSys } & + & & $-0.696 * * *$ & & & & & & \\
\hline & & & $-(2.64)$ & & & & & & \\
\hline \multirow[t]{2}{*}{ RuleofLaw } & + & & & $-1.922 * * *$ & & & & & \\
\hline & & & & $-(3.00)$ & & & & & \\
\hline \multirow[t]{2}{*}{ Corruption } & + & & & & $-1.634 * * *$ & & & & \\
\hline & & & & & $-(2.98)$ & & & & \\
\hline \multirow[t]{2}{*}{ ExtCap } & + & & & & & -2.462 & & & \\
\hline & & & & & & $-(1.60)$ & & & \\
\hline \multirow[t]{2}{*}{ DoFirms } & + & & & & & & $-0.050 * *$ & & \\
\hline & & & & & & & $-(2.22)$ & & \\
\hline IPOs & & & & & & & & $-(1.30)$ & \\
\hline \multirow[t]{2}{*}{ Ownership } & - & & & & & & & & 5.940 \\
\hline & & & & & & & & & $(1.45)$ \\
\hline \multirow[t]{2}{*}{ Pub_enf } & + & $-12.871 * * *$ & $-12.250 * * *$ & $-12.708 * * *$ & $-12.561 * * *$ & $-10.828 * * *$ & $-9.670 * * *$ & $-11.469 * * *$ & $-11.694 * * *$ \\
\hline & & $-(4.90)$ & $-(5.42)$ & $-(5.62)$ & $-(5.56)$ & $-(4.54)$ & $-(3.89)$ & $-(4.96)$ & $-(5.11)$ \\
\hline F-value & & $13.8^{* * *}$ & $17.4 * * *$ & $18.7 * * *$ & $18.5^{* * *}$ & $15.0 * * *$ & $16.3^{* * *}$ & $14.5^{* * *}$ & $14.7 * * *$ \\
\hline Adj. $\mathrm{R}^{2}$ & & $10.6 \%$ & $13.2 \%$ & $14.1 \%$ & $13.9 \%$ & $11.4 \%$ & $12.4 \%$ & $11.1 \%$ & $11.2 \%$ \\
\hline $\mathrm{N}$ & & 217 & 217 & 217 & 217 & 217 & 217 & 217 & 217 \\
\hline
\end{tabular}

$* * *, * * *$ denote the coefficient estimates that are significantly different then zero at the $1 \%, 5 \%$, and $10 \%$ levels, respectively (two-tailed).

$\mathrm{t}$-values are reported in parentheses (two-tailed). 
TABLE 7 (Continued)

Country-Year Regression Analysis Between Earnings Attributes and Investor Protection Proxies

Panel B: Earnings persistence rank score ("R_Persist”) and institutional characteristic

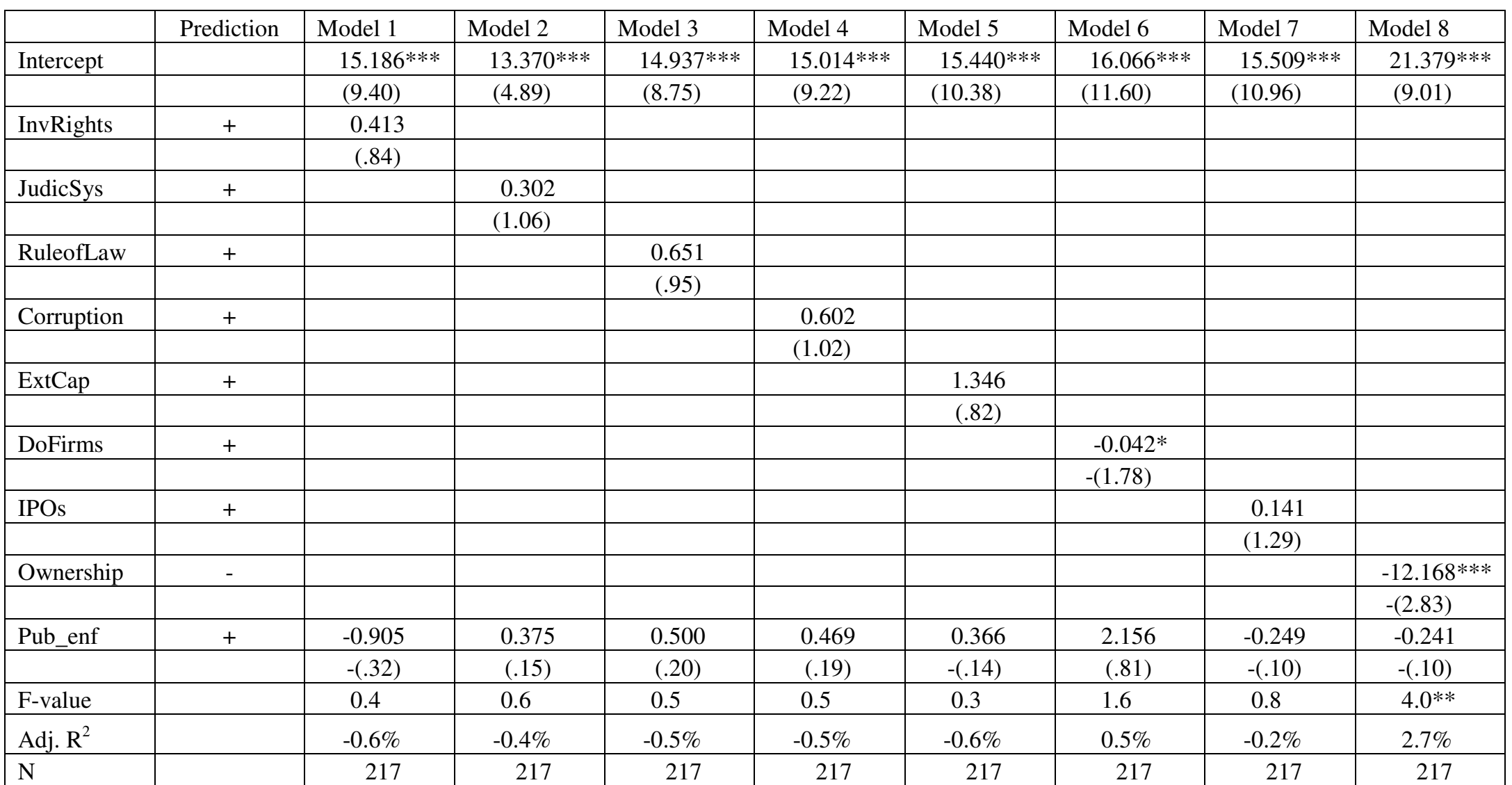

***,**,* denote the coefficient estimates that are significantly different then zero at the $1 \%, 5 \%$, and $10 \%$ levels, respectively (two-tailed).

$\mathrm{t}$-values are reported in parentheses (two-tailed). 
TABLE 7 (Continued)

Country-Year Regression Analysis Between Earnings Attributes and Investor Protection Proxies

Panel C: Earnings predictability rank score ("R_Pred”) and institutional characteristic

\begin{tabular}{|c|c|c|c|c|c|c|c|c|c|}
\hline & Prediction & Model 1 & Model 2 & Model 3 & Model 4 & Model 5 & Model 6 & Model 7 & Model 8 \\
\hline \multirow[t]{2}{*}{ Intercept } & & $22.196 * * *$ & $29.274 * * *$ & $24.833 * * *$ & $24.699 * * *$ & $22.915 * * *$ & $22.005 * * *$ & $22.099 * * *$ & $18.630 * * *$ \\
\hline & & $(14.44)$ & $(11.54)$ & $(15.68)$ & $(16.46)$ & $(16.41)$ & $(17.12)$ & $(16.46)$ & $(8.15)$ \\
\hline \multirow[t]{2}{*}{ InvRights } & + & -0.331 & & & & & & & \\
\hline & & $-(.71)$ & & & & & & & \\
\hline \multirow[t]{2}{*}{ JudicSys } & + & & $-0.918 * * *$ & & & & & & \\
\hline & & & $-(3.49)$ & & & & & & \\
\hline \multirow[t]{2}{*}{ RuleofLaw } & + & & & $-2.207 * * *$ & & & & & \\
\hline & & & & $-(3.46)$ & & & & & \\
\hline \multirow[t]{2}{*}{ Corruption } & + & & & & $-2.129 * * *$ & & & & \\
\hline & & & & & $-(3.90)$ & & & & \\
\hline \multirow[t]{2}{*}{ ExtCap } & + & & & & & $-3.908 * *$ & & & \\
\hline & & & & & & $-(2.54)$ & & & \\
\hline \multirow[t]{2}{*}{ DoFirms } & + & & & & & & $-0.083 * * *$ & & \\
\hline & & & & & & & $-(3.75)$ & & \\
\hline IPOs & & & & & & & & $-(1.68)$ & \\
\hline \multirow[t]{2}{*}{ Ownership } & - & & & & & & & & 6.659 \\
\hline & & & & & & & & & $(1.61)$ \\
\hline \multirow[t]{2}{*}{ Pub_enf } & + & $-10.083 * * *$ & $-11.423 * * *$ & $-11.893 * * *$ & $-11.823 * * *$ & $-9.252 * * *$ & $-7.235 * * *$ & $-10.398 * * *$ & $-10.736 * * *$ \\
\hline & & $-(3.80)$ & $-(5.06)$ & $-(5.24)$ & $-(5.26)$ & $-(3.88)$ & $-(2.94)$ & $-(4.46)$ & $-(4.65)$ \\
\hline F-value & & $11.5^{* * *}$ & $18.0 * * *$ & $17.9 * * *$ & $19.7 * * *$ & $14.8 * * *$ & $19.0 * * *$ & $12.8 * * *$ & $12.7 * * *$ \\
\hline Adj. $\mathrm{R}^{2}$ & & $8.9 \%$ & $13.6 \%$ & $13.5 \%$ & $14.7 \%$ & $11.4 \%$ & $14.3 \%$ & $9.9 \%$ & $9.8 \%$ \\
\hline $\mathrm{N}$ & & 217 & 217 & 217 & 217 & 217 & 217 & 217 & 217 \\
\hline
\end{tabular}

***,**,* denote the coefficient estimates that are significantly different then zero at the $1 \%, 5 \%$, and $10 \%$ levels, respectively (two-tailed).

$\mathrm{t}$-values are reported in parentheses (two-tailed). 
TABLE 7 (Continued)

\section{Country-Year Regression Analysis Between Earnings Attributes and Investor Protection Proxies}

Panel D: Earnings smoothness rank score ("R_Smooth”) and institutional characteristic

\begin{tabular}{|c|c|c|c|c|c|c|c|c|c|}
\hline & Prediction & Model 1 & Model 2 & Model 3 & Model 4 & Model 5 & Model 6 & Model 7 & Model 8 \\
\hline \multirow[t]{2}{*}{ Intercept } & & $8.596 * * *$ & 0.485 & $6.668 * * *$ & $7.154 * * *$ & $7.797 * * *$ & $9.622 * * *$ & $9.490 * * *$ & $16.515 * * *$ \\
\hline & & $(5.68)$ & $(.20)$ & $(4.26)$ & (4.78) & (5.79) & $(7.41)$ & $(7.12)$ & $(7.48)$ \\
\hline \multirow[t]{2}{*}{ InvRights } & + & 0.744 & & & & & & & \\
\hline & & $(1.61)$ & & & & & & & \\
\hline \multirow[t]{2}{*}{ JudicSys } & + & & $1.125 * * *$ & & & & & & \\
\hline & & & $(4.39)$ & & & & & & \\
\hline \multirow[t]{2}{*}{ RuleofLaw } & + & & & $2.196 * * *$ & & & & & \\
\hline & & & & (3.48) & & & & & \\
\hline \multirow[t]{2}{*}{ Corruption } & + & & & & $1.874 * * *$ & & & & \\
\hline & & & & & $(3.44)$ & & & & \\
\hline \multirow[t]{2}{*}{ ExtCap } & + & & & & & $6.279 * * *$ & & & \\
\hline & & & & & & $(4.24)$ & & & \\
\hline \multirow[t]{2}{*}{ DoFirms } & + & & & & & & $0.051 * *$ & & \\
\hline & & & & & & & $(2.27)$ & & \\
\hline IPOs & & & & & & & & $(1.31)$ & \\
\hline \multirow[t]{2}{*}{ Ownership } & - & & & & & & & & $-14.755^{* * *}$ \\
\hline & & & & & & & & & $-(3.69)$ \\
\hline \multirow[t]{2}{*}{ Pub_enf } & + & $9.946 * * *$ & $12.523 * * *$ & $12.892 * * *$ & $12.728 * * *$ & $9.196 * * *$ & $9.700 * * *$ & $11.536 * * *$ & $11.423 * * *$ \\
\hline & & $(3.81)$ & (5.69) & (5.74) & $(5.68)$ & $(4.0)$ & $(3.91)$ & $(4.99)$ & $(5.12)$ \\
\hline F-value & & $15.2 * * *$ & $24.6 * * *$ & $20.5 * * *$ & $20.4 * * *$ & $23.8 * * *$ & $16.6 * * *$ & $14.7 * * *$ & $21.4 * * *$ \\
\hline Adj. $\mathrm{R}^{2}$ & & $11.6 \%$ & $17.9 \%$ & $15.3 \%$ & $15.2 \%$ & $17.4 \%$ & $12.6 \%$ & $11.2 \%$ & $15.9 \%$ \\
\hline $\mathrm{N}$ & & 217 & 217 & 217 & 217 & 217 & 217 & 217 & 217 \\
\hline
\end{tabular}

***,**,* denote the coefficient estimates that are significantly different then zero at the $1 \%, 5 \%$, and $10 \%$ levels, respectively (two-tailed).

$\mathrm{t}$-values are reported in parentheses (two-tailed). 
TABLE 7 (Concluded)

Country-Year Regression Analysis Between Earnings Attributes and Investor Protection Proxies

Models:

Model 1: Earnings attribute $=\mathrm{f}($ InvRights $)+$ control variable

Model 2: Earnings attribute $=\mathrm{f}($ JudicSys $)+$ control variable

Model 3: Earnings attribute $=\mathrm{f}($ Ruleoflaw $)+$ control variable

Model 4: Earnings attribute $=\mathrm{f}($ Corruption $)+$ control variable

Model 5: Earnings attribute $=\mathrm{f}($ ExtCap $)+$ control variable

Model 6: Earnings attribute $=\mathrm{f}($ DoFirms $)+$ control variable

Model 7: Earnings attribute $=\mathrm{f}($ IPOs $)+$ control variable

Model 8: Earnings attribute $=\mathrm{f}($ Ownership $)+$ control variable

Variable Definitions:

R_Stdresid is a descending rank score of "Stdresid", with the high rank score (31) implying high earnings quality.

R_Persist is an ascending rank score of "Persist", with the high rank score (31) implying high earnings quality.

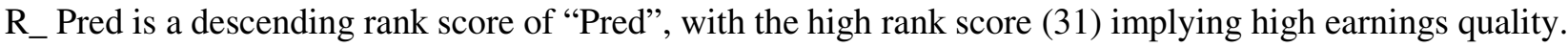

R_Smooth is a descending rank score of "Smooth), with the high rank score (31) implying high earnings quality.

InvRights is the antidirector rights index.

JudicSys is the efficiency of the judicial system index.

RuleofLaw is the rule of law index, mentioned earlier.

Corruption is the corruption index.

ExtCap is the ratio of external capitalization to gross domestic product ratio.

DoFirms is the ratio of the number of domestic firms to its population (in millions).

IPOs is the ratio of the equity issued newly-listed firms in a given country (in thousands) to its gross domestic product (in millions).

Ownership is the ownership concentration percentage.

Note: Full investor protection variable definitions are explained in Table 2. 
TABLE 8

Sensitivity Test 1: Regression Analysis Between Earnings Attributes and Investor Protection Proxies

Panel A: Accruals quality (rank score) and institutional characteristic (rank data)

\begin{tabular}{|c|c|c|c|c|c|c|c|c|c|}
\hline & Prediction & Model 1 & Model 2 & Model 3 & Model 4 & Model 5 & Model 6 & Model 7 & Model 8 \\
\hline \multirow[t]{2}{*}{ Intercept } & & $20.600 * * *$ & $24.219 * * *$ & $24.373 * * *$ & $24.382 * * *$ & $22.519 * * *$ & $23.265^{* * *}$ & $23.562 * * *$ & $19.210 * * *$ \\
\hline & & $(15.24)$ & (15.69) & $(15.21)$ & $(15.60)$ & $(15.85)$ & $(16.42)$ & $(16.32)$ & $(11.65)$ \\
\hline \multirow[t]{2}{*}{ R_InvRights } & + & 0.038 & & & & & & & \\
\hline & & $(.50)$ & & & & & & & \\
\hline \multirow[t]{2}{*}{ R_JudicSys } & + & & $-0.214 * * *$ & & & & & & \\
\hline & & & $-(3.26)$ & & & & & & \\
\hline \multirow[t]{2}{*}{ R_RuleofLaw } & + & & & $-0.201 * * *$ & & & & & \\
\hline & & & & $-(3.15)$ & & & & & \\
\hline \multirow[t]{2}{*}{ R_Corruption } & + & & & & $-0.211 * * *$ & & & & \\
\hline & & & & & $-(3.32)$ & & & & \\
\hline \multirow[t]{2}{*}{ R_ExtCap } & + & & & & & $-0.136 * *$ & & & \\
\hline & & & & & & $-(2.03)$ & & & \\
\hline \multirow[t]{2}{*}{ R_DoFirms } & + & & & & & & $-0.193 * * *$ & & \\
\hline & & & & & & & $-(2.94)$ & & \\
\hline \multirow[t]{2}{*}{ R_IPOs } & + & & & & & & & $-0.201 * * *$ & \\
\hline & & & & & & & & $-(3.11)$ & \\
\hline \multirow[t]{2}{*}{ R_Ownership } & - & & & & & & & & 0.097 \\
\hline & & & & & & & & & (1.49) \\
\hline \multirow[t]{2}{*}{ R_Pub_enf } & + & $-0.325 * * *$ & $-0.300 * * *$ & $-0.323 * * *$ & $-0.313 * * *$ & $-0.272 * * *$ & $-0.261 * * *$ & $-0.271 * * *$ & $-0.298 * * *$ \\
\hline & & $-(4.37)$ & $-(4.72)$ & $-(5.05)$ & $-(4.93)$ & $-(4.06)$ & $-(3.97)$ & $-(4.19)$ & $-(4.57)$ \\
\hline F-value & & $11.3 * * *$ & $17.0 * * *$ & $16.6 * * *$ & $17.2 * * *$ & $13.4 * * *$ & $15.9 * * *$ & $16.5 * * *$ & $12.4 * * *$ \\
\hline Adj. $\mathrm{R}^{2}$ & & $8.7 \%$ & $12.9 \%$ & $12.6 \%$ & $13.1 \%$ & $10.3 \%$ & $12.1 \%$ & $12.5 \%$ & $9.5 \%$ \\
\hline $\mathrm{N}$ & & 217 & 217 & 217 & 217 & 217 & 217 & 217 & 217 \\
\hline
\end{tabular}

$* * *, * *, *$ denote the coefficient estimates that are significantly different then zero at the 1\%, $5 \%$, and $10 \%$ levels, respectively (two-tailed).

t-values are reported in parentheses (two-tailed). Note: The index of public enforcement equals the arithmetic mean of: (1) Supervisor characteristics index; (2) Rule-making power index; (3) Investigative powers index; (4) Orders index; and (5) Criminal index based on La Porta et al. (2004). 
TABLE 8 (Continued)

Sensitivity Test 1: Regression Analysis Between Earnings Attributes and Investor Protection Proxies

Panel B: Earnings persistence (rank score) and Institutional Characteristic (rank data)

\begin{tabular}{|c|c|c|c|c|c|c|c|c|c|}
\hline & Prediction & Model 1 & Model 2 & Model 3 & Model 4 & Model 5 & Model 6 & Model 7 & Model 8 \\
\hline \multirow[t]{2}{*}{ Intercept } & & $15.374 * * *$ & $14.984 * * *$ & $15.399 * * *$ & $14.455^{* * *}$ & $14.756 * * *$ & $15.978 * * *$ & $14.263 * * *$ & $19.532 * * *$ \\
\hline & & $(10.83)$ & $(9.03)$ & $(8.95)$ & $(8.62)$ & $(9.84)$ & $(10.52)$ & $(9.26)$ & $(11.46)$ \\
\hline \multirow[t]{2}{*}{ R_InvRights } & + & 0.063 & & & & & & & \\
\hline & & $(.79)$ & & & & & & & \\
\hline \multirow[t]{2}{*}{ R_JudicSys } & + & & 0.059 & & & & & & \\
\hline & & & $(.84)$ & & & & & & \\
\hline \multirow[t]{2}{*}{ R_RuleofLaw } & + & & & 0.029 & & & & & \\
\hline & & & & $(.43)$ & & & & & \\
\hline \multirow[t]{2}{*}{ R_Corruption } & + & & & & 0.088 & & & & \\
\hline & & & & & $(1.29)$ & & & & \\
\hline \multirow[t]{2}{*}{ R_ExtCap } & + & & & & & 0.097 & & & \\
\hline & & & & & & $(1.38)$ & & & \\
\hline \multirow[t]{2}{*}{ R_DoFirms } & + & & & & & & -0.006 & & \\
\hline & & & & & & & $-(.09)$ & & \\
\hline \multirow[t]{2}{*}{ R_IPOs } & + & & & & & & & 0.125 & \\
\hline & & & & & & & & $(1.81)$ & \\
\hline \multirow[t]{2}{*}{ R_Ownership } & - & & & & & & & & $-0.207 * * *$ \\
\hline & & & & & & & & & $-(3.07)$ \\
\hline \multirow[t]{2}{*}{ R_Pub_enf } & + & -0.024 & 0.004 & 0.008 & 0.009 & -0.019 & 0.008 & -0.016 & -0.014 \\
\hline & & $-(.31)$ & $(.06)$ & $(.12)$ & $(.13)$ & $-(.27)$ & $(.11)$ & $-(.23)$ & $-(.21)$ \\
\hline F-value & & 0.3 & 0.4 & 0.1 & 0.8 & 1.0 & 0.0 & 1.6 & $4.7 * * *$ \\
\hline Adj. $\mathrm{R}^{2}$ & & $-0.6 \%$ & $-0.6 \%$ & $-0.9 \%$ & $-0.2 \%$ & $0.0 \%$ & $-0.9 \%$ & $0.6 \%$ & $3.3 \%$ \\
\hline $\mathrm{N}$ & & 217 & 217 & 217 & 217 & 217 & 217 & 217 & 217 \\
\hline
\end{tabular}

***,**,* denote the coefficient estimates that are significantly different then zero at the $1 \%, 5 \%$, and $10 \%$ levels, respectively (two-tailed).

t-values are reported in parentheses (two-tailed). Note: The index of public enforcement equals the arithmetic mean of: (1) Supervisor characteristics index; (2) Rule-making power index; (3) Investigative powers index; (4) Orders index; and (5) Criminal index based on La Porta et al. (2004). 
TABLE 8 (Continued)

Sensitivity Test 1: Regression Analysis Between Earnings Attributes and Investor Protection Proxies

Panel C: Earnings predictability (rank score) and Institutional Characteristic (rank data)

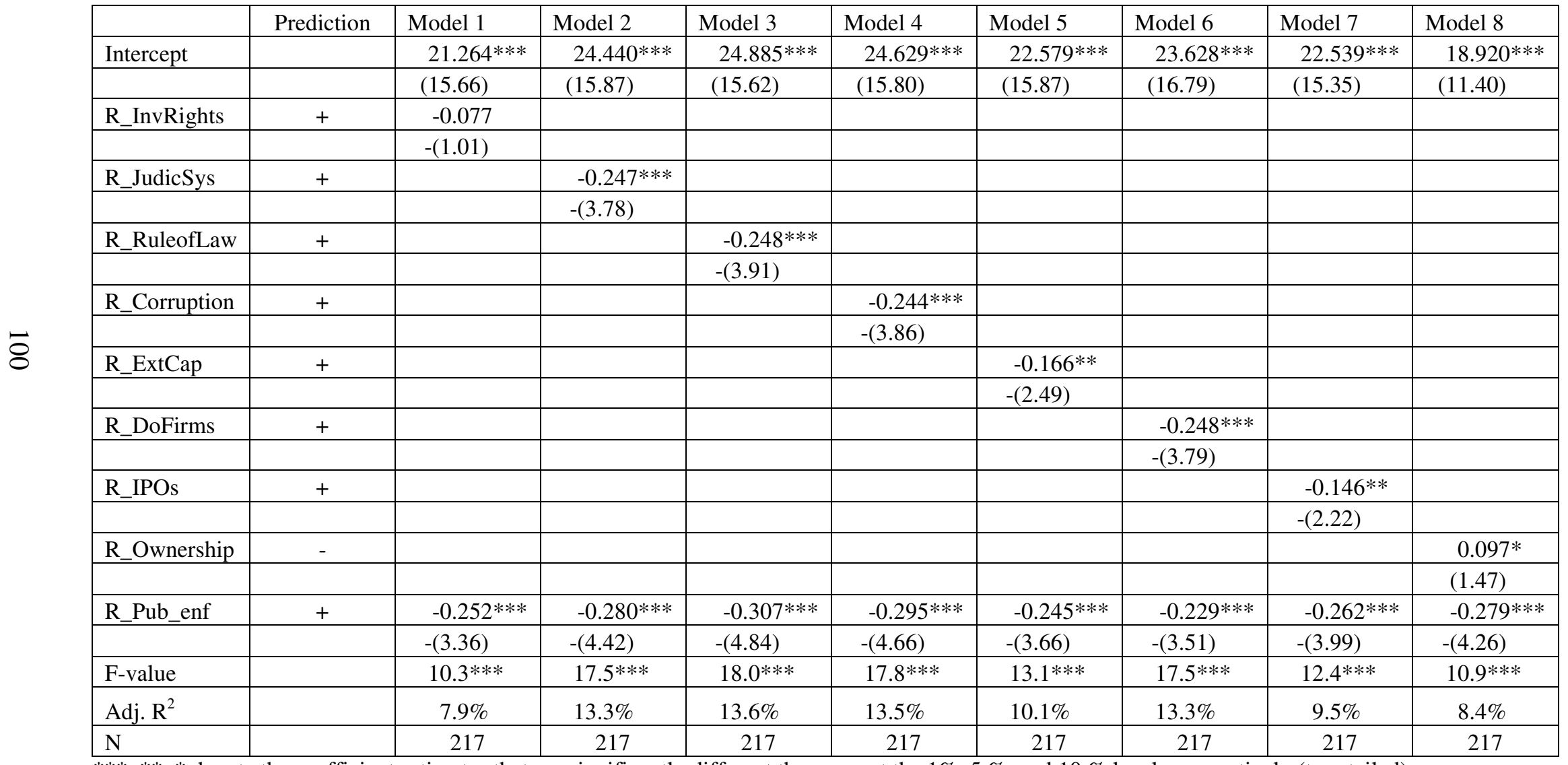

$* * *, * *, *$ denote the coefficient estimates that are significantly different then zero at the $1 \%, 5 \%$, and $10 \%$ levels, respectively (two-tailed).

t-values are reported in parentheses (two-tailed). Note: The index of public enforcement equals the arithmetic mean of: (1) Supervisor characteristics index; (2) Rule-making power index; (3) Investigative powers index; (4) Orders index; and (5) Criminal index based on La Porta et al. (2004). 
TABLE 8 (Continued)

Sensitivity Test 1: Regression Analysis Between Earnings Attributes and Investor Protection Proxies

Panel D: Earnings smoothness (rank score) and Institutional Characteristic (rank data)

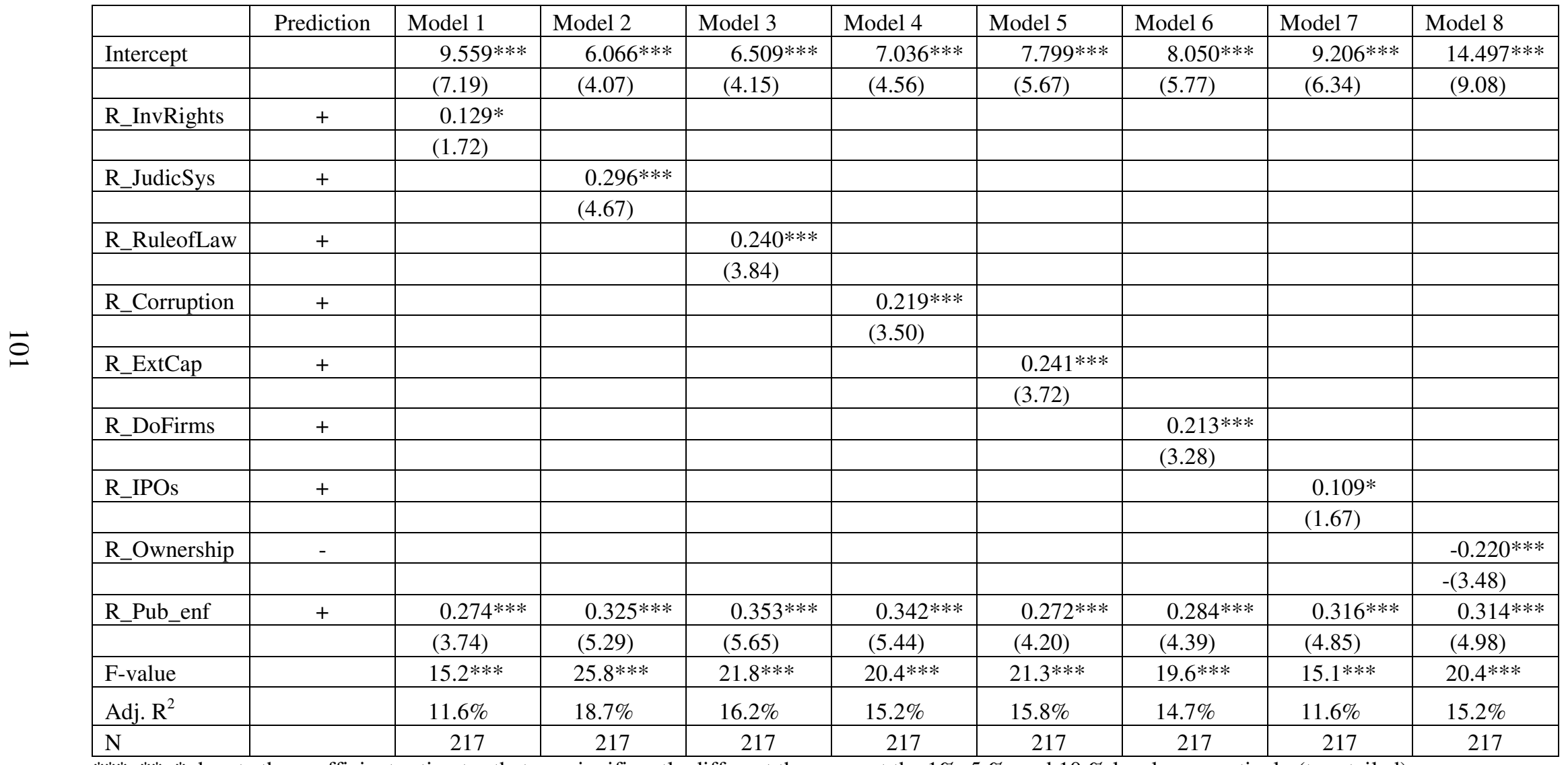

$* * *, * *, *$ denote the coefficient estimates that are significantly different then zero at the $1 \%, 5 \%$, and $10 \%$ levels, respectively (two-tailed).

t-values are reported in parentheses (two-tailed). Note: The index of public enforcement equals the arithmetic mean of: (1) Supervisor characteristics index; (2) Rule-making power index; (3) Investigative powers index; (4) Orders index; and (5) Criminal index based on La Porta et al. (2004). 


\section{TABLE 8 (Concluded)}

Sensitivity Test 1: Regression Analysis Between Earnings Attributes and Investor Protection Proxies

Models:

Model 1: Earnings attribute $=\mathrm{f}\left(\mathrm{R} \_\right.$InvRights $)+$control variable

Model 2: Earnings attribute $=\mathrm{f}\left(\mathrm{R} \_\right.$JudicSys $)+$control variable

Model 3: Earnings attribute $=\mathrm{f}\left(\mathrm{R} \_\right.$Ruleoflaw $)+$control variable

Model 4: Earnings attribute $=\mathrm{f}\left(\mathrm{R} \_\right.$Corruption $)+$control variable

Model 5: Earnings attribute $=\mathrm{f}\left(\mathrm{R} \_\right.$ExtCap $)+$control variable

Model 6: Earnings attribute $=f\left(R \_D o F i r m s\right)+$ control variable

Model 7: Earnings attribute $=\mathrm{f}\left(\mathrm{R} \_I P O s\right)+$ control variable

Model 8: Earnings attribute $=\mathrm{f}\left(\mathrm{R} \_\right.$Ownership $)+$control variable

\section{Variable Definitions:}

R_Stdresid is a descending rank score of "Stdresid", with the high rank score (31) implying high earnings quality.

R_Persist is an ascending rank score of "Persist", with the high rank score (31) implying high earnings quality.

R_ Pred is a descending rank score of "Pred", with the high rank score (31) implying high earnings quality.

R_Smooth is a descending rank score of "Smooth), with the high rank score (31) implying high earnings quality.

R_InvRights

R_JudicSys

R RuleofLaw

R_Corruption

R_ExtCap

R_DoFirms

R_IPOs

R_Ownership
$=$ Rank score of "InvRights" in an ascending order, with high rank score (31) implying high investor protection.

$=$ Rank score of "JudicSys" in an ascending order, with high rank score (31) implying high investor protection.

$=$ Rank score of "RuleofLaw" in an ascending order, with high rank score (31) implying high investor protection.

$=$ Rank score of "Corruption" in an ascending order, with high rank score (31) implying high investor protection.

$=$ Rank score of "ExtCap" in an ascending order, with high rank score (31) implying high investor protection.

$=$ Rank score of "DoFirms" in an ascending order, with high rank score (31) implying high investor protection.

$=$ Rank score of "IPOs" in an ascending order, with high rank score (31) implying high investor protection.

$=$ Rank score of "Ownership" in an ascending order, with high rank score (31) implying low investor protection. 
TABLE 9

Sensitivity Test 2: Country-Year Correlation Matrix

This table presents Spearman-rank correlation matrix of results when all accounting variables are scaled using averaged total assets instead of lagged total assets.

Panel A: Spearman-rank correlation matrix between earnings attributes

\begin{tabular}{|l|c|c|c|c|c|c|c|c|}
\hline & \multicolumn{4}{|c|}{ Predicted Sign } & \multicolumn{5}{c|}{ Spearman Rank Correlation } \\
\cline { 2 - 9 } & Stdresid & Persist & Pred & Smooth & Stdresid & Persist & Pred & Smooth \\
\hline Stdresid & 1.000 & & & & 1.000 & & & \\
\hline Persist & - & 1.000 & & & $-0.114^{*}$ & 1.000 & & \\
\hline Pred & + & - & 1.000 & & $0.839 * * *$ & $-0.241 * * *$ & 1.000 & \\
\hline Smooth & + & - & + & 1.000 & $-0.614 * * *$ & 0.025 & $-0.715^{* * *}$ & 1.000 \\
\hline & & & & $\mathrm{N}$ & 217 & 217 & 217 & 217 \\
\hline
\end{tabular}

$* * *, * *, *$ denote $1 \%$ significance, $5 \%$ significance, and 10\% significance, respectively (two-tailed).

Panel B: Spearman-rank correlation matrix between institutional characteristics and earnings attributes (rank score)

\begin{tabular}{|c|c|c|c|c|c|c|c|c|}
\hline & \multicolumn{4}{|c|}{ Predicted Sign } & \multicolumn{4}{|c|}{ Spearman Rank Correlation } \\
\hline & R_Stdresid & R_Persist & R_Pred & R_Smooth & R_Stdresid & R_Persist & R_Pred & R_Smooth \\
\hline InvRights & + & + & + & + & -0.110 & 0.100 & $-0.224 * * *$ & $0.254 * * *$ \\
\hline JudicSys & + & + & + & + & $-0.201 * * *$ & 0.066 & $-0.230 * * *$ & $0.297 * * *$ \\
\hline RuleofLaw & + & + & + & + & $-0.160 * *$ & 0.044 & $-0.203 * * *$ & $0.228 * * *$ \\
\hline Corruption & + & + & + & + & $-0.164 * *$ & 0.097 & $-0.197 * * *$ & $0.200 * * *$ \\
\hline ExtCap & + & + & + & + & $-0.185 * * *$ & $0.123 *$ & $-0.218 * * *$ & $0.299 * * *$ \\
\hline DoFirms & + & + & + & + & $-0.244 * * *$ & 0.046 & $-0.308 * * *$ & $0.305^{* * *}$ \\
\hline IPOs & + & + & + & + & $-0.174 * *$ & $0.157 * *$ & $0.132 * *$ & $0.176^{* * *}$ \\
\hline Ownership & - & - & - & - & 0.060 & $-0.215^{* * *}$ & 0.077 & $-0.208 * * *$ \\
\hline & & & & $\mathrm{N}$ & 217 & 217 & 217 & 217 \\
\hline
\end{tabular}

$* * *, * *, *$ denote $1 \%$ significance, $5 \%$ significance, and $10 \%$ significance, respectively (two-tailed). 
TABLE 9 (Concluded)

Sensitivity Test 2: Country-Year Correlation Matrix

Variable Definitions:

- Accruals quality is measured by the standard deviation of the estimated residuals (Stdresid) from pooled firm-year regressions per country and year of changes in working capital on last year, present, and one-year ahead cash flows from operations, consistent with Dechow and Dichev (2002) and McNichols (2002).

- Earnings persistence is the slope coefficient estimates (Persist) from pooled firm-year regressions per country and year of current earnings on last year earnings.

- Earnings predictability (Pred) is the square root of the error variance from earnings persistence equation.

- Earnings smoothness (Smooth) is the ratio of the country-year standard deviation of operating cash flows to the standard deviation of earnings.

- R_Stdresid is a descending rank score of "Stdresid", with the high rank score (31) implying high earnings quality.

- R_Persist is an ascending rank score of "Persist", with the high rank score (31) implying high earnings quality.

- R_Pred is a descending rank score of "Pred", with the high rank score (31) implying high earnings quality.

- R_Smooth is a descending rank score of "Smooth), with the high rank score (31) implying high earnings quality.

- InvRights is the antidirector rights index.

- JudicSys is the efficiency of the judicial system index.

- RuleofLaw is the rule of law index, mentioned earlier.

- Corruption is the corruption index.

- ExtCap is the ratio of external capitalization to gross domestic product ratio.

- DoFirms is the ratio of the number of domestic firms to its population (in millions).

- IPOs is the ratio of the equity issued newly-listed firms in a given country (in thousands) to its gross domestic product (in millions).

- Ownership is the ownership concentration percentage. 
TABLE 10

Sensitivity Test 3: Country-Year Correlation Matrix

This table presents Spearman-rank correlation matrix of results if change in tax payable is not part of the calculation for total accruals and total current accruals as follows:

$$
\begin{aligned}
\mathrm{TA}_{\mathrm{j}, \mathrm{t}} & =\text { Firm j's total accruals in year t. } \\
& =\left(\Delta \mathrm{CA}_{\mathrm{j}, \mathrm{t}}-\Delta \mathrm{CL}_{\mathrm{j}, \mathrm{t}}-\Delta \mathrm{Cash}_{\mathrm{j}, \mathrm{t}}+\Delta \mathrm{STDEBT}_{\mathrm{j}, \mathrm{t}}-\mathrm{Dep}_{\mathrm{j}, \mathrm{t}}\right) . \\
\text { TCAj,t } & =\text { Firm j's total current accruals in year t. } \\
& =\left(\Delta \mathrm{CA}_{\mathrm{j}, \mathrm{t}}-\Delta \mathrm{CL}_{\mathrm{j}, \mathrm{t}}-\Delta \mathrm{Cash}_{\mathrm{j}, \mathrm{t}}+\Delta \mathrm{STDEBT}_{\mathrm{j}, \mathrm{t}}\right) .
\end{aligned}
$$

Panel A: Spearman-rank correlation matrix between earnings attributes

\begin{tabular}{|l|c|c|c|c|c|c|c|c|}
\hline & \multicolumn{4}{|c|}{ Predicted Sign } & \multicolumn{4}{c|}{ Spearman Rank Correlation } \\
\cline { 2 - 9 } & Stdresid & Persist & Pred & Smooth & Stdresid & Persist & Pred & Smooth \\
\hline Stdresid & 1.000 & & & & 1.000 & & & \\
\hline Persist & - & 1.000 & & & 0.028 & 1.000 & & \\
\hline Pred & + & - & 1.000 & & $0.857^{* * *}$ & $-0.140^{* *}$ & 1.000 & \\
\hline Smooth & + & - & + & 1.000 & $-0.482^{* * *}$ & -0.047 & $-0.576^{* * *}$ & 1.000 \\
\hline & & & & $\mathrm{N}$ & 217 & 217 & 217 & 217 \\
\hline
\end{tabular}

$* * *, * *, *$ denote $1 \%$ significance, $5 \%$ significance, and 10\% significance, respectively (two-tailed).

\section{Variable Definitions:}

- Accruals quality is measured by the standard deviation of the estimated residuals (Stdresid) from pooled firm-year regressions per country and year of changes in working capital on last year, present, and one-year ahead cash flows from operations, consistent with Dechow and Dichev (2002) and McNichols (2002).

- Earnings persistence is the slope coefficient estimates (Persist) from pooled firm-year regressions per country and year of current earnings on last year earnings.

- Earnings predictability (Pred) is the square root of the error variance from earnings persistence equation.

- Earnings smoothness (Smooth) is the ratio of the country-year standard deviation of operating cash flows to the standard deviation of earnings. 
TABLE 10 (Concluded)

Sensitivity Test 3: Country-Year Correlation Matrix

Panel B: Spearman-rank correlation matrix between institutional characteristics and earnings attributes (rank score)

\begin{tabular}{|c|c|c|c|c|c|c|c|c|}
\hline & \multicolumn{4}{|c|}{ Predicted Sign } & \multicolumn{4}{|c|}{ Spearman Rank Correlation } \\
\hline & R_Stdresid & R_Persist & R_Pred & R_Smooth & R_Stdresid & R_Persist & R_Pred & R_Smooth \\
\hline InvRights & + & + & + & + & $-0.123^{*}$ & 0.050 & $-0.196 * * *$ & $0.239 * * *$ \\
\hline JudicSys & + & + & + & + & $-0.209 * * *$ & 0.057 & $-0.250 * * *$ & $0.285 * * *$ \\
\hline RuleofLaw & + & + & + & + & $-0.172 * *$ & 0.029 & $-0.225 * * *$ & $0.202 * * *$ \\
\hline Corruption & + & + & + & + & $-0.195 * * *$ & 0.088 & $-0.237 * * *$ & $0.204 * * *$ \\
\hline ExtCap & + & + & + & + & $-0.205 * * *$ & 0.092 & $-0.231 * * *$ & $0.303 * * *$ \\
\hline DoFirms & + & + & + & + & $-0.268 * * *$ & -0.009 & $-0.310 * * *$ & $0.271 * * *$ \\
\hline IPOs & + & + & + & + & $-0.233 * * *$ & $0.128 *$ & $-0.178 * * *$ & $0.171 * *$ \\
\hline \multirow[t]{2}{*}{ Ownership } & - & - & - & - & $0.114 *$ & $-0.203 * * *$ & $0.123^{*}$ & $-0.224 * * *$ \\
\hline & & & & $\mathrm{N}$ & 217 & 217 & 217 & 217 \\
\hline
\end{tabular}

***, $* *, *$ denote $1 \%$ significance, $5 \%$ significance, and 10\% significance, respectively (two-tailed).

Variable Definitions:

- R_Stdresid is a descending rank score of "Stdresid", with the high rank score (31) implying high earnings quality.

- R_Persist is an ascending rank score of "Persist", with the high rank score (31) implying high earnings quality.

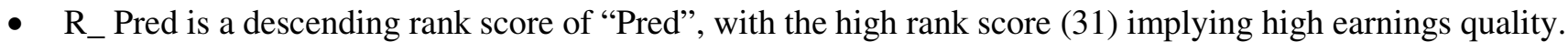

- R_Smooth is a descending rank score of "Smooth), with the high rank score (31) implying high earnings quality.

- InvRights is the antidirector rights index.

- JudicSys is the efficiency of the judicial system index.

- RuleofLaw is the rule of law index, mentioned earlier.

- Corruption is the corruption index.

- ExtCap is the ratio of external capitalization to gross domestic product ratio.

- DoFirms is the ratio of the number of domestic firms to its population (in millions).

- IPOs is the ratio of the equity issued newly-listed firms in a given country (in thousands) to its gross domestic product (in millions).

- Ownership is the ownership concentration percentage. 


\section{FIGURE 1}

Empirical Relations between Earnings Attributes and Investor Protection
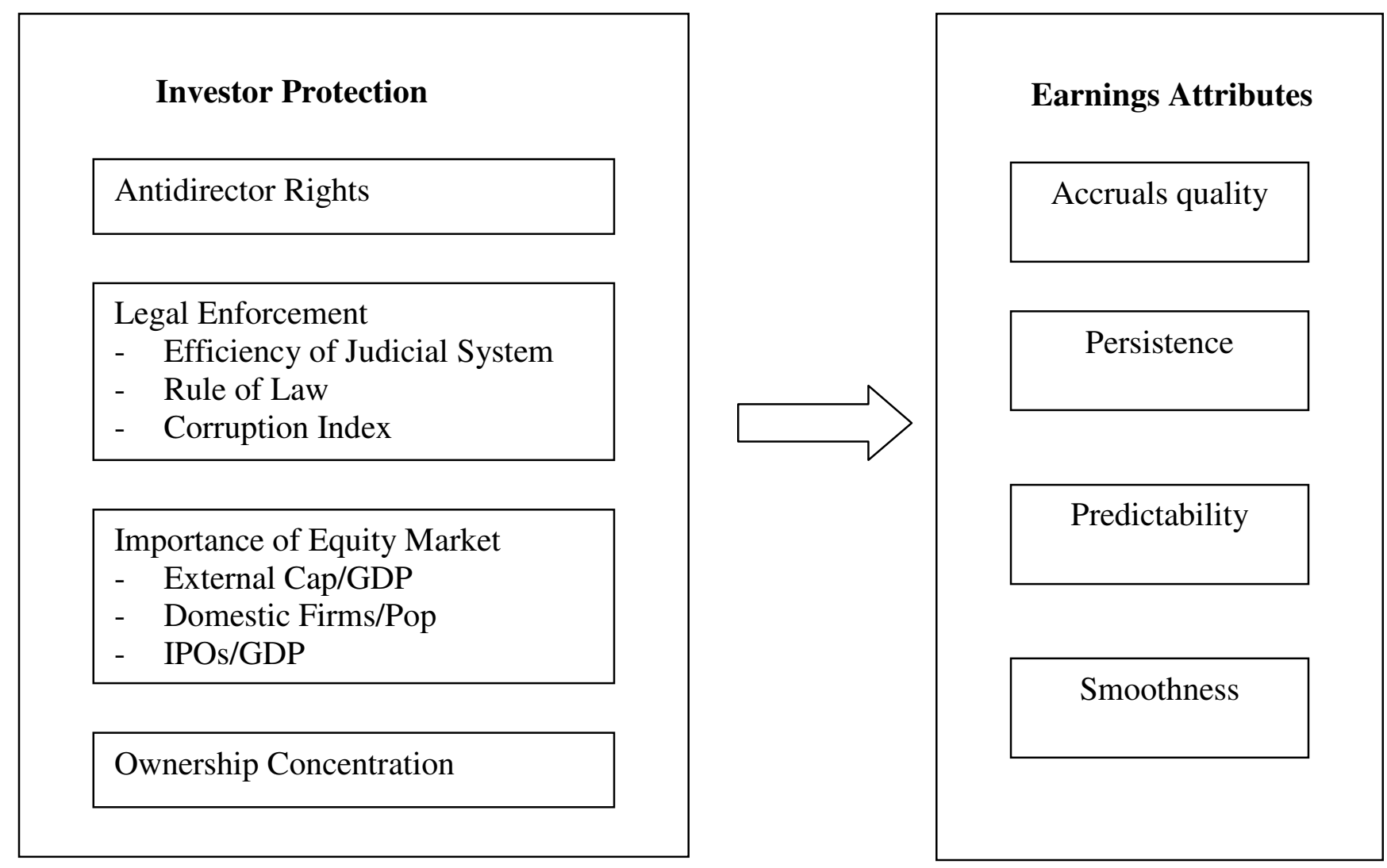
VITA

\author{
Kriengkrai Boonlert-U-Thai \\ Candidate for the Degree of \\ Doctor of Philosophy
}

\title{
Thesis: EARNINGS ATTRIBUTES AND INVESTOR PROTECTION: INTERNATIONAL EVIDENCE
}

Major Field: Business Administration - Accounting

Biographical:

Personal Data: Born in Bangkok, Thailand on October 2, 1971, the son of Supod and Malee Boonlert-U-Thai.

Education: Graduated with a Bachelor of Business Administration (Accounting) from Rajamankala University of Technology, Thanyaburi, Thailand in March 1993; received Master of Accountancy degree from Chulalongkorn University, Bangkok, Thailand in March 1995; received the Master of Science degree in Accounting from Oklahoma State University in August 2001. Completed the requirements for the Doctor of Philosophy degree with a major in Business Administration Accounting at Oklahoma State University in December 2005.

Experience: Accounting Lecturer, Faculty of Commerce and Accountancy, Chulalongkorn University, Thailand, 1995 to present.

Honors and Awards: Wilton T. Anderson Distinguished Graduate Fellowship, AAA Southwest Doctoral Consortium, AAA Financial Accounting and Reporting Section Doctoral Consortium, AAA International Accounting Section Doctoral Consortium, AAAA Doctoral Consortium (Seoul, Korea), and Illinois International Accounting Conference (Kobe, Japan).

Professional Memberships: American Accounting Association, Canadian Academic Accounting Association, American Finance Association, Asian Academic Accounting Association, and Phi Kappa Phi. 